\author{
UNIVERSIDADE DE SÃO PAULO \\ FACULDADE DE FILOSOFIA, LETRAS E CIÊNCIAS HUMANAS \\ DEPARTAMENTO DE CIÊNCIA POLÍTICA \\ PROGRAMA DE PÓS-GRADUAÇÃO EM CIÊNCIA POLÍTICA
}

\title{
Povo e polícia, uma só direção: os estreitos canais de participação dos conselhos comunitários de segurança da cidade de São Paulo
}

Roberta Corradi Astolfi

Dissertação apresentada ao Programa de Pós-Graduação em Ciência Política do Departamento de Ciência Política da Faculdade de Filosofia, Letras e Ciências Humanas da Universidade de São Paulo, para a obtenção do título de Mestre em Ciência Política.

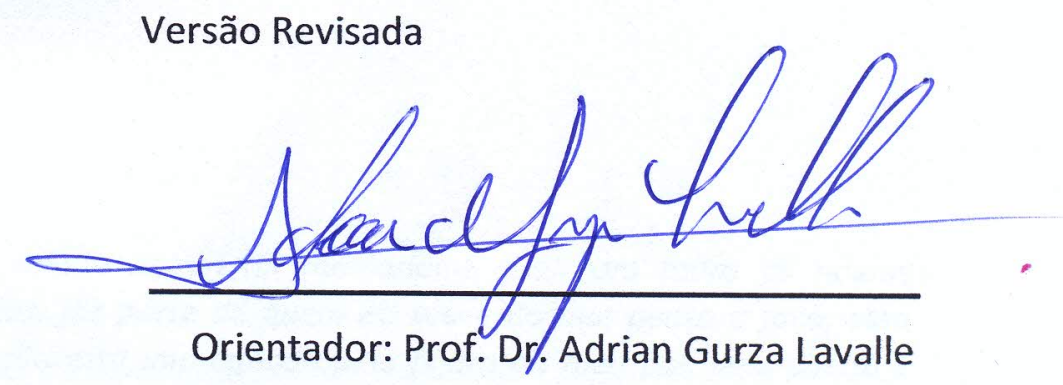

São Paulo

2014 
A João Adolfo Astolfi (in memoriam) que, com todas as nossas diferenças, faz parte de quem eu sou e do que penso e faço; essa dissertação está impregnada pela figura do meu pai, pelo direito e pelo avesso. A Alex Andrade, meu companheiro incansável; sem ele eu não teria passado do primeiro mês, talvez nem da primeira semana. E à minha mãe, Sônia Maria Corradi Astolfi por... tudo. 


\section{AGRADECIMENTOS}

Sempre desconfiei que os agradecimentos no início de testes e dissertações fossem uma opção política de boa vizinhança, uma espécie de demagogia elegante e necessária, que alinhavasse relações utilíssimas para ganhos futuros. De tudo o que aprendi nesses quase três anos de mestrado, a maior lição foi compreender o valor da ajuda.

Em primeiro lugar, fui ajudada pelo meu orientador, Adrian Gurza Lavalle, às vezes cruel, sugerindo mais do que minhas pernas davam conta de correr, e extremamente generoso, jamais me deixou desassistida e um dos melhores professores que já conheci. Pelos inúmeros colegas do Departamento de Ciência Política da USP, que deram dicas e ajudaram com questionamentos nos corredores e salas da faculdade ou no grupo de correio eletrônico do departamento (a lista mágica), o que contradisse em muito o que muitas vezes ouvi da arrogância e competitividade dos habitantes do ambiente acadêmico. Pelos professores com quem fiz disciplinas e pela banca de qualificação: professores Rogério Bastos Arantes e Marcos Cesar Alvarez. Também me ajudaram Maria Raimunda dos Santos (a competentíssima e queridíssima Rai), Vasne dos Santos, Ana Maria Capel e Leo, funcionários do DCP cujo auxílio cotidiano foi de inestimável valor, às vezes só faltava nos levarem pelas mãos através do inevitável labirinto da burocracia acadêmica.

Fui muito ajudada por meus amigos do Núcleo de Estudos da Violência, em muitas coisas e agradeço a Marcelo Batista Nery, Altay Sousa, Rafael Cinoto e Maria Fernanda Tourinho Peres pelas aluas de estatística; a Caren Ruotti, Maria Gorete de Jesus, Marcelo Nery, Denise Carvalho pelas trocas de ideias e sugestões bibliográficas; a Mariana Thorsthensen Possas, Maria Gorete de Jesus, Marcelo Batista Nery, Mariana Vieira, Denise Carvalho, Vitor Lima Blotta, Sérgia Santos, Jucilia Pereira (in memoriam), Wânia Pasinato e Renato Antônio Alves pelo apoio emocional. Agradeço a Frederico Castelo Branco e Ariadne Natal pelas trocas e ideias. Aos coordenadores professor Sérgio Adorno, Nancy Cardia e Paulo Sergio Pinheiro que me apoiaram mesmo quando tive que limitar drasticamente minhas atividades no NEV para me dedicar ao mestrado. Fui ajudada por pessoas que conheci no NEV e que seguiram outros caminhos há tempos: Patrícia Carla Santos também ajudou com as discussões sobre técnicas estatísticas e Vanessa Orban com discussões teóricas e apoio emocional. Minhas queridas amigas Gorete e Vanessa, experientes em trabalho de campo, me acompanharam às minhas primeiras reuniões de Conseg.

Fui ajudada pelos colegas do Núcleo Democracia e Ação Coletiva do Centro Brasileiro de Análise e Planejamento: Maira Rodrigues, Hellen Guicheney, Monika Dowbor, José Eduardo Leon 
Szwako, Wagner Romão, Maria do Carmo Albuquerque, Osmany Porto de Oliveira, Jessica Voigt, Luciana Martins, Thiago Greghi que gentil e pacientemente leram uma das versões do capítulo teórico e devolveram críticas valiosas.

Ana Paula Galdeano, autora da minha primeira leitura sobre os Consegs, enviou-me material de pesquisa e indicações bibliográficas.

Também sou grata à ajuda da minha família: minha mãe Sônia e meus irmãos Giuliano e Giovana que se resignaram com a falta de atenção dos meses que precederam o depósito e aceitaram pacientemente e (quase) sem cobranças, o meu isolamento; a minha cunhada, Simone Miotto Astolfi, que em tempo recorde me ajudou com o tratamento do material digitalizado. Nessa tarefa também me ajudou Maria Cristina Jakimiak Fernandes.

Agradeço também a todos os membros da diretoria, membros natos e participantes dos Consegs em cujas reuniões realizei parte da pesquisa: Capão Redondo, Pari, Sapopemba, Jardins/Paulistas, Itaim Bibi, Perdizes/Pacaembu, Mandaqui e Liberdade. E também ao pessoal da Secretaria de Segurança Pública que me ajudou com a pesquisa das atas: o coordenador geral dos Consegs do Estado de São Paulo, Evaldo Corato e os servidores Thais Costa Barbosa, Silvio Ferreira e Wagner Sting. A Cristina Neme, da Coordenadoria de Análise e Planejamento da SSP-SP, pelos dados de criminalidade enviados.

Agradeço por fim a Alex Andrade, que segurou a minha mão pra atravessar a ponte sobre o vale das inseguranças e medos exagerados. Chego ao outro lado sem glórias ou orgulhos de um grande feito, mas com um sentimento incrível de alegria por ter atravessado. 
Juntos agora vamos dar as mãos Com alegria e muita união Na busca de soluções Abrimos os corações Nossas famílias é que vão ganhar O cidadão merece segurança Para poder trabalhar e crescer Vamos legar a todas as crianças Um mundo bom onde possam viver Povo e polícia uma só direção Com seriedade e dedicação Humanizando a cidade O bairro e o quarteirão Nosso conselho nos dá voz e ação Lá lá lá lá ... Humanizando a Humanizando a cidade O bairro e o quarteirão Nosso conselho nos dá voz e ação (Canção dos Consegs, SSP-SP, 2011) 
RESUMO

Os Conselhos Comunitários de Segurança são uma das várias instituições participativas que apareceram no país desde a década de 1980. Já foram objetos de grande entusiasmo e de igual decepção. Esse trabalho busca compreender os Consegs da cidade de São Paulo de uma forma transversal, com método quantitativo buscando entender seu funcionamento e prática nos diferentes contextos de renda, escolaridade e crime. Dessa forma serão testados os diagnósticos mais pessimistas - de que os Consegs são espaços propícios para a reprodução de representações preconceituosas e estigmatizadoras de certos grupos sociais. E também aqueles mais otimistas de que os Consegs produzirão, pela prática do diálogo, comportamentos cívicos e racionais. Além disso, informações históricas serão mobilizadas para propor uma explicação sobre a situação atual dessas instituições.

Palavras-chave: neo-institucionalismo, Conselhos Comunitários de Segurança, segurança pública, direitos humanos, sociedade civil.

\section{ABSTRACT}

The Community Councils of Public Security are one instance among others of participative institutions that flourished in Brazil since 1980. They have been considered sometimes with great hope and enthusiasm and other times with exaggerated criticism. This research sought describe and understand how this institutions work throughout the various contexts of the city of São Paulo regarding differences in income, education and crime rates. The intention is to test previous diagnoses: first, those that are more pessimistic and believe that these spaces tend to worsen prejudice and segregation against certain social groups of people. Also will be challenged those diagnoses that are more optimistic and believe that the dialog and reason will produce civic learning. Also, historic information are retrieved in order to propose an explanation for the present situation of these institutions.

Key words: neoinstitutionalism, Community Councils of Public Security, public security, human rights, civil society. 


\section{Sumário}

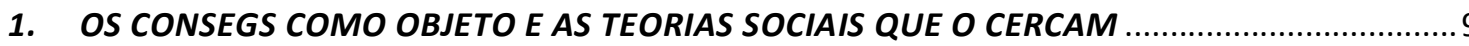

1.1. Estudos sobre crime e violência no Brasil: autoritarismo, hierarquias e desrespeito aos direitos civis. E por cima de tudo: a cultura do controle.

1.2. Estudos sobre crime e violência no Brasil tendo os Conselhos Comunitários de Segurança

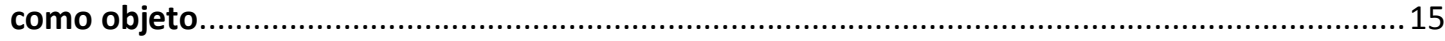

1.3. Os estudos sobre participação: a abordagem da sociedade civil e o polity approach ......24

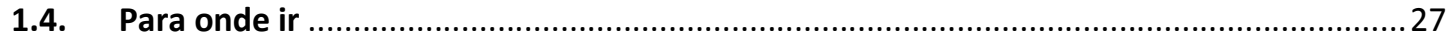

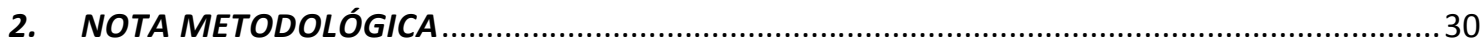

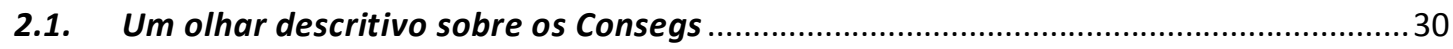

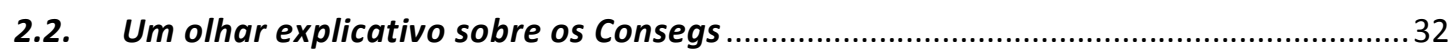

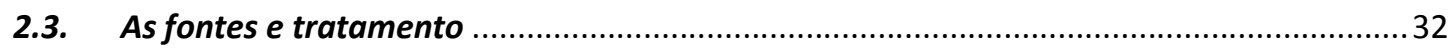

3. REGRAS DE FUNCIONAMENTO E HISTÓRIA INSTITUCIONAL DOS CONSEGS EM SÃO PAULO 40

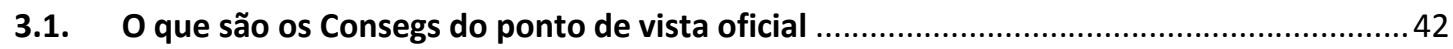

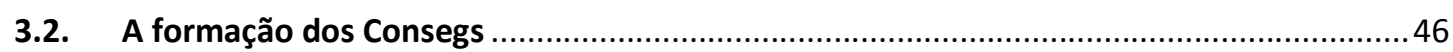

3.3. A normatização: disputa na ampliação das atribuições dos Consegs .............................54

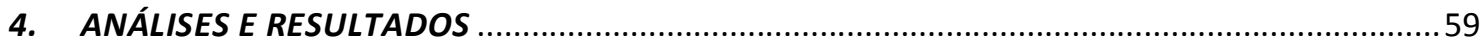

4.1 Qual a relação dos atores da política formal com os participantes dos Consegs? ...........59

4.2 Desigualdade e igualdade em direitos e cidadania............................................... 74

4.3 O desejo difuso de lei e ordem como preditor da participação .....................................80

4.4 A inversão da autoridade ou, as possibilidades de ação autônoma dos atores societais. 82

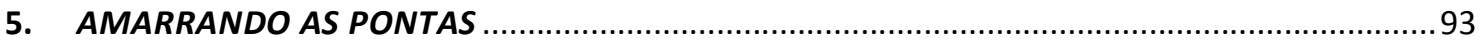

5.1. Institucionalização precária e atuação dos atores societais ........................................93

5.2. Arquitetando a participação nos momentos de grande inovação institucional ...............94

5.3. A questão dos direitos civis de um lado e direitos sociais e políticos de outro ...............95

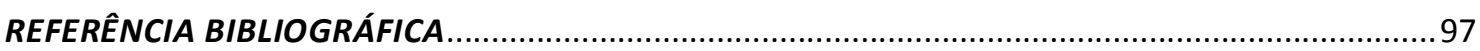

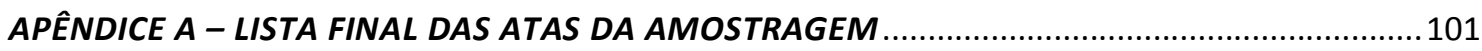

APÊNDICE B - TABELAS COMPARATIVAS DOS MODELOS ANÁLISES DE REGRESSÃO ................103 
INTRODUÇÃO:

Os Conselhos Comunitários de Segurança Pública - Consegs - são instituições de participação dos cidadãos na segurança pública criados no governo Franco Montoro em 1985. A área de cada Conseg corresponde àquela coberta por cada distrito policial e a cidade de São Paulo tem hoje quase tantos Consegs quanto DPs. Ligados ao governo estadual através de uma coordenadoria alocada na Secretaria Estadual de Segurança Pública, os Consegs são fontes de decepção e esperança para ativistas de direitos humanos e especialistas da área de política de segurança pública.

São fonte de decepção porque nesses espaços é mais comum ouvir reclamações sobre como os direitos humanos atrapalham o trabalho da polícia ${ }^{1}$ do que demandas por uma atuação policial respeitadora da lei e garantidora dos direitos fundamentais dos cidadãos. Essa decepção se aprofunda quando as interpretações apontam para o diagnóstico de que a continuidade das reuniões dos Consegs no tempo irá produzir mais desaprovação em relação aos direitos civis.

São fontes de esperança quando alguns supõem ser possível que a contínua interação entre Estado e sociedade civil produzirá uma espécie de aprendizado cívico, um aperfeiçoamento produzido nas interações baseadas no debate racional e livre, de inspiração habermasiana. Ou quando percebem que os Consegs também são espaços de inversão do lugar de autoridade entre cidadãos e representantes do Estado.

Este trabalho busca verificar esses diagnósticos a partir de método quantitativo e formular descrições nuançadas e, a partir de uma análise neo-institucional, propor explicações alternativas. 0 neo-institucionalismo será trazido em três variações: a) As regras do jogo importam. A hipótese mestra do neo-institucionalismo será tomada primeiramente em um sentido mais simples e direto, de que o regulamento dos Consegs é fundamental na forma como os atores se comportam nessas instituições participativas; b) Polity approach: no sentido de que o posicionamento dos atores societais em momento de inovação institucional garante precedência na área de política (HOUTZAGER, 2003.; LAVALLE, 2011a e 2011) e c) A institucionalização precária de certos arranjos participativos (GURZA LAVALLE, 2011b) dificulta a influência dos atores na área de política, o que também é uma formulação do polity approach.

No capítulo um serão revisadas as interpretações sobre crime, medo e violência que serviram de lente para a observação dos Consegs, bem como as interpretações sobre os Consegs

\footnotetext{
${ }^{1}$ Isso não quer dizer que esse tipo de manifestação seja frequente, pelo menos atualmente. Mais adiante será argumentado que o próprio regulamento do Conseg influencia na contenção de manifestações contra os direitos fundamentais como solução para os problemas da criminalidade.
} 
propriamente ditas. Termino o capítulo colocando os problemas específicos com os quais as pesquisa pretende lidar. No capítulo dois estão descritos os métodos de pesquisa e elencadas as fontes e o tratamento dado a cada uma em detalhes. 0 capítulo três narra a gênese desses espaços participativos, a partir de um contexto de tensão na política no estado de São Paulo e no plano federal. Mostra também as tentativas de modificar os Consegs a partir da ação de atores do legislativo estadual a situação atual em termos de regulamento. As análises quantitativas e a discussão com a literatura serão apresentados no capítulo quatro. O capítulo cinco amarra as pontas entre hipóteses, achados e interpretação institucionalista. 


\section{OS CONSEGS COMO OBJETO E AS TEORIAS SOCIAIS QUE O CERCAM}

Ao estudar a punição, o sociólogo David Garland (1993) propôs que esta fosse tratada como uma instituição e, como tanto, deveria ser pensada a partir de uma ideia de sobredeterminação, (overdetermination), visando a enfatizar que o objeto de seu estudo possuía diferentes aspectos sociais, econômicos e culturais -, e cuja compreensão poderia se valer de teorias diversas já desenvolvidas para pensar esses diferentes aspectos, dada sua pluralidade e multidimensionalidade. Garland realizou uma revisão crítica dos estudos sobre a punição pensando nas contribuições e limites de cada um e deu também sua própria contribuição pensando seus aspectos culturais, aspectos que, segundo ele, teriam sido negligenciados. De forma semelhante, embora em uma escala mais modesta, busco nesta pesquisa olhar para o objeto - o Conselho Comunitário de Segurança - compreendendo-o como um objeto sobredeterminado. Cada estudo de fôlego sobre os Consegs que tive oportunidade de estudar tem como framework teórico uma diferente teoria social, ou uma diferente combinação de teorias sociais e cada um deles parece imprescindível para descrever o que se passa nesses espaços. Assim como Garland, que traz novas teorias para dar corpo à compreensão de um objeto já estudado, esta pesquisa busca fazer também sua contribuição, analisando os Consegs a partir da referência ao neo-institucionalismo, tanto em uma apropriação mais livre quanto na vertente específica do polity approach.

Ao mergulharem fundo em abordagens etnográficas ou adotando uma visão quase que puramente teórica do objeto, os estudos existentes deixaram muito espaço para a construção do conhecimento a respeito dos Consegs e ainda não formaram um corpo de literatura suficientemente denso. Neste capítulo serão revisadas as interpretações sobre crime, medo e violência que serviram de lente para a observação dos Consegs, bem como as interpretações sobre os Consegs propriamente ditas e para isso, será percorrido um caminho que remonta ao final da década de 1970.

\subsection{Estudos sobre crime e violência no Brasil: autoritarismo, hierarquias e desrespeito aos direitos civis. E por cima de tudo: a cultura do controle.}

A falta de um modelo para pensar uma democracia sem direitos civis (CARNEIRO, 2003) tem desconcertado os cientistas sociais brasileiros há mais de vinte anos. O campo de estudos sobre crime, medo e violência formou-se mais ou menos concomitantemente ao processo de redemocratização e grande parte do problema era entender a ausência de legitimidade dos direitos civis, mais especificamente dos direitos e garantias de suspeitos de crimes comuns, na sociedade ao 
mesmo tempo que se sucediam os avanços no plano da política nacional: o fim da censura, anistia aos dissidentes políticos, assembleia constituinte, promulgação da Constituição Cidadã e eleições livres para presidente. A falta de apoio às garantias básicas dos cidadãos considerados perigosos ou potencialmente perigosos assustava os estudiosos tanto quanto a criminalidade crescente assustava a população. A partir de uma pesquisa de opinião realizada em 1985, Soares e Carneiro (1996) encontraram muito presente aquilo que chamaram de "opinião pública despótica ou asiática" (Ibidem, passim): percepções que focavam nos pobres e favelados como motivadores da violência e da criminalidade e prescreviam intervenções de grande magnitude e violência para lidar com eles, tais como migrações forçadas, esterilização em massa de mulheres faveladas, desalojamento de favelas e execução sumária de criminosos indesejáveis. Esse tipo de manifestação correndo em paralelo ao tão acalentado sonho da democratização, intrigava. O problema de práticas autoritárias no campo da segurança pública e o apoio da opinião pública a essas práticas - muitas vezes pensada em termos de cultura política - tornou-se central para o campo em formação. Um corpo de literatura foi formado, com referências que até hoje "firmam perspectivas" (ADORNO, 2002, p.3) e influenciam o debate acadêmico, determinando um modo próprio de construção do seu objeto.

A partir de uma chave implícita ou explicitamente marshalliana, com ênfase na ideia de interdependência entre os direitos, os estudos nesse corpo de literatura foram paulatinamente testando associações - ora entre direitos civis e direitos políticos, ora entre direitos civis e direitos sociais, ora entre todos eles juntos - para tentar descobrir onde estava o dente quebrado da engrenagem que poderia explicar a falta de legitimidade dos direitos civis entre os brasileiros. Se as práticas policiais eram bastante violentas, se a população demandava políticas de segurança pública excessivamente repressivas, era preciso investigar que outra geração de direitos apresentava mal funcionamento.

Roberto DaMatta e a ideia da percepção dual de cidadania (do indivíduo e da pessoa) (1997 [1979]), Wanderley Guilherme dos Santos (1994) com o conceito de cidadania regulada e a obra de José Murilo de Carvalho (2001), com suas três classes de cidadãos, embora não tivessem como questão central a questão do crime, medo e violência, foram muito influentes nesses campos e cada uma foi adotada como referenciais teóricos importantes em diferentes momentos.

Durante o processo de redemocratização e até o fim do século XX, as taxas de criminalidade, que vinham aumentando sistematicamente pelo menos desde os anos setenta, ganhavam espaço na preocupação cotidiana da população. Por um lado, a constituição do campo parece ter sido motivada por esse aumento do crime e, por outro, a forma como se constituiu parece estar intimamente ligada às preocupações do debate político da época, como já nos referimos 
anteriormente. Nesse contexto, o primeiro grupo de direitos disfuncionais foco da atenção dos estudiosos foi o grupo dos direitos sociais, mais especificamente a questão da pobreza e centenas de páginas foram escritas com o objetivo de tentar desfazer a associação entre esse fenômeno e a criminalidade. Se os pobres já não tinham garantidos seus direitos sociais, eram ainda por cima estigmatizados pela sociedade e, em consequência, vítimas da repressão violenta do Estado e da ação ilegal de grupos de extermínio. Os argumentos para negar a associação entre criminalidade e pobreza passavam pela denúncia de vieses na produção de estatísticas criminais (COELHO, 1978, 1980; SOARES et al, 1996), pela negação de qualquer conduta baseada na escolha racional com o argumento de que se o crime fosse resultado de um cálculo de custo e benefício, a maior parte dos pobres tornar-se-ia criminosa (COELHO, 1980; ZALUAR; 2000 [1985], 1994 [1986]) e pela tese da profecia auto cumprida do estigma que empurraria os pobres, especialmente os jovens, para o mundo do crime em função de uma identidade constituída contra a representação dos inimigos comuns: a polícia violenta e a sociedade preconceituosa e culturalmente hierárquica (COELHO, 1980; ZALUAR; 2000 [1985], 1994 [1986]; PERALVA, 2000 E FELTRAN, 2011). Com a evolução da qualidade dos dados estatísticos sobre ocorrências criminais, tornava-se evidente que, embora nem todas as áreas mais pobres fossem violentas, de modo geral, as áreas onde ocorriam grande quantidade de crimes violentos eram muito pobres de modo que parte do campo recolocou a questão invertendo a perspectiva do que seria o criminoso pobre para a perspectiva da vítima pobre que sofreria de "múltiplas carências econômico-sociais, o que constitui terreno fértil para que a violência prospere" (CARDIA, ADORNO e POLETO, 2003, p. 1; CARDIA, 2003).

Os direitos políticos também foram investigados como direitos disfuncionais. A ampliação dos direitos políticos com o estabelecimento do sufrágio universal para todos os maiores de 16 anos, inclusive para os analfabetos e uma "generalização do sentimento de igualdade" (PERALVA, 2000, p. 56) teriam entrado em rota de colisão com os valores tradicionais dessa sociedade culturalmente hierárquica, que não permitia o reconhecimento do novo lugar dos pobres, gerando crime e hiperrepressão como ação e reação em uma espiral de crescente violência (CALDEIRA, 2000; PERALVA, 2000). Nesse processo, a "fala do crime" (Caldeira, 2000, passim) teria um papel fundamental, servindo como narrativa organizadora de um mundo desorganizado por todas as inseguranças da vida cotidiana, tais como a crise econômica e também o próprio crime. Se por um lado a fala do crime daria sentido às experiências dos indivíduos, ela reproduziria imagens estereotipadas do criminoso, modos de vida segregados e mais violência. A radicalização do argumento de que haveria um descompasso entre os direitos formais e o caráter hierárquico e desigual da sociedade é que haveria um bloqueio da voz dos jovens pobres e dos defensores dos direitos destes ao tentarem canalizar demandas de forma legítima no plano político (PINHEIRO 2001; FELTRAN, 2011). A 
interpretação de Carneiro (2003) guarda maior semelhança com a sequência de Marshall: "a extensão dos direitos políticos foi conquistada sem o desenvolvimento correto das instituições desenhadas para garantir as liberdades civis" (CARNEIRO, 2003). Carneiro também faz o caminho de volta: o desrespeito aos direitos civis certamente viria a ter impacto sobre o sistema e os direitos políticos.

Há também interpretações que articulam de forma conjunta as três categorias de direitos. A modernização das estruturas sociais, inspiradas pelo processo democrático de certos países capitalistas não teria sido assimilada pela prática política e pela sociedade, impedindo que os direitos civis e políticos se efetivassem fora da esfera das elites econômicas (ADORNO, 1996, 2002). Por trás desse processo haveria o "o autoritarismo socialmente implantando", um traço social brasileiro ao mesmo tempo causa e efeito dos processos políticos formais e da desigualdade socioeconômica (ADORNO, 1996; PINHEIRO 2001).

Independente do grau de avanço nos direitos sociais e/ou políticos que essas interpretações admitem, é possível reconhecer que todas elas fazem parte de uma mesma linhagem que tenta compreender por que há tanta desigualdade - e apoio a essa desigualdade -no gozo dos direitos civis relacionados à justiça, repressão policial e aplicação da lei, ainda mais quando o sujeito é aquele considerado perigoso, o suspeito, o pobre, o morador da favela. Nessa linhagem, há desde interpretações mais unidimensionais em que consensos sociais em favor da igualdade para certos direitos como educação e saúde, são considerados fenômenos que apenas escondem práticas sociais excludentes tal como na caracterização do "paradoxo legal brasileiro" de Kant de Lima $(1997,2004)$ até outras multidimensionais como a "democracia disjuntiva", (CALDEIRA, 2000) que não ignora o fato de que os direitos sociais e políticos são relativamente legitimados no Brasil, mesmo que não o sejam os direitos civis.

Paralelamente, estudos sociológicos sobre prisão e punição começaram a chamar a atenção dos cientistas sociais brasileiros ${ }^{2}$. Tendo como referência países capitalistas ricos como os EUA, Inglaterra e França, por exemplo, autores como Michel Wieviorka, Loïc Wacquant, Zygmunt Bauman e David Garland, tentavam descrever e entender mudanças na percepção geral sobre crime e prisão (SALLA, GAUTO e ALVAREZ, 2006). As ideologias de humanização das punições e da responsabilização parcial do Estado pelo crime teriam começado a refluir nesses países a partir de meados dos anos 1970, o que se veria no crescimento da demanda por lei e ordem, ou da "cultura

\footnotetext{
${ }^{2}$ As duas vertentes analisada aqui - aquela dos direitos e a da sociologia da punição - certamente não são as únicas que inspiraram os estudos sobre crime, medo e violência no Brasil. Outras correntes se desenvolveram, tal como a da escolha racional, mas essa revisão se restringe àquelas que inspiraram os estudos teoricamente orientados sobre os Consegs.
} 
do controle" (GARLAND, 2005). Os autores vêm debatendo a explicação para esses fenômenos que poderia estar calcada na emergência de novas formas de violência e novas percepções sobre ela:

No interior dos países ocidentais, a começar pela França, a violência subjetiva, tal qual é sentida, apresenta como primeira característica fundamental a de parecer ter perdido qualquer legitimidade no espaço político, quase a ponto de significar o mal absoluto; ela é o que a sociedade, unânime, deve proscrever e combater completamente, tanto em seu interior como em seu exterior. Nos anos 60 e 70, a violência podia ainda ser justificada ou compreendida por intelectuais que eventualmente se inscreviam eles próprios em uma tradição revolucionária, anarquista ou ainda marxista-leninista; ela podia ser teorizada ou sustentada com uma certa adesão, e ser tolerada na esfera política" (WIEVIORKA, 1997).

A explicação para a mudança - a emergência da cultura do controle - poderia estar também relacionada ao declínio do estado de bem estar social e à necessidade de segregação que os guetos já não dariam mais conta de suprir (WACQUANT, 2008). Além disso nesse contexto, propagar um ideário e adotar práticas de dureza contra o crime seria a única forma de governos convencerem as pessoas de que estavam fazendo alguma coisa para aumentar algum tipo de segurança, já que não poderiam fazer nada a respeito das inseguranças trazidas pela globalização e flexibilização dos direitos trabalhistas (BAUMANN, 1999).

Nessas descrições, uma tendência de endurecimento penal, dirigida prioritariamente a grupos estigmatizados da sociedade (pobres, negros, imigrantes, extremistas religiosos), podia ser vista por exemplo em casos de políticas de policiamento urbano conhecidas pelo jargão tolerância zero, que buscavam conter mesmo as menores ilegalidades; e leis do tipo three strikes and you are out, que limitavam as garantias jurídicas para reincidentes. Ambas tiveram como consequência um elevado crescimento nas taxas de encarceramento nos EUA enquanto em várias partes do mundo ocidental ocorriam fenômenos semelhantes (SALLA, GAUTO e ALVAREZ, 2006). Os autores da sociologia da punição descrevem um contexto em que reprimir as menores ilegalidades era parte importante da agenda política, de um determinado paradigma de segurança pública. Mesquita Neto (2011) identifica esse paradigma com a teoria das janelas quebradas, em que a manutenção do espaço público é parte da prevenção primária da violência. A teoria das janelas quebradas e o paradigma de tolerância zero, teriam forjado a percepção de uma espécie de continuum entre crimes graves e pequenas ilegalidades, entre práticas tão diversas como pichar muros, vender drogas, roubar e matar. 
Como apropriar-se dessas teorias para o caso brasileiro onde dificilmente se poderia falar em refluxo de um penal welfarism ${ }^{3}$ - que aparentemente não existiu por aqui -, e nem sequer as tecnologia da disciplina incorpórea dos corpos dóceis, conforme teorizada por Foucault, havia sido atingida (CALDEIRA, 2000) visto a brutalidade contra o corpo das mulheres, das crianças, dos loucos e dos perigosos? Se por um lado os direitos civis de certos grupos jamais foram garantidos no país, o que nos afasta da descrição do ocidente rico, por outro lado, o aumento das taxas de encarceramento desde a década de 1990, pelo menos no estado de São Paulo, deu-se no mesmo sentido daquele descrito pelos sociólogos franceses e ingleses. A versão brasileira da guerra as drogas teria sido responsável por boa parte desse encarceramento, impedindo que suspeitos de crime de tráfico desfrutassem de garantias processuais tais como o direito de responder ao processo em liberdade (JESUS et al., 2011). No entanto, a própria legislação de drogas tinha um componente que apontava no sentido contrário: o fim das penas de prisão para aqueles classificados como usuários.

Essa sociologia aponta para um fenômeno novo, ou melhor, para o refluxo inesperado de um certo consenso social sobre o papel da punição em sociedades com regimes poliárquicos estáveis em países ricos. Interessante apontar é que o que essa sociologia descreve em termos de resistência a atribuição dos direitos civis e garantias processuais para certos grupos estigmatizados, é muito semelhante à descrição do que ocorreria no Brasil, a diferença é que deste lado do mundo, a causa está colocada, ao menos parcialmente, nos traços hierárquicos, duais, ambíguos e parcialmente modernos da sociedade brasileira, uma característica de longa duração, que se atualiza a cada novo período de autoritarismo político. Como separar o que é velho (a falta de garantia dos direitos civis) do que é novo (o aumento significativo das taxas de encarceramento em alguns estados brasileiros)? Adorno (2002) expôs um problema análogo: como falar em perda do monopólio estatal da violência por parte do Estado-nação no mundo globalizado (como formulara Wieviorka) para o caso brasileiro onde o Estado weberiano nem sequer teria se completado (e talvez nem devesse sê-lo)? Pode ser o caso que ocorra no Brasil uma sobreposição de fenômenos: um deles tradicional e específico, ao qual viria a se superpor outro que é novo e comum ao mundo ocidental.

Em uma síntese sobre o pensamento de David Garland ${ }^{4}$ Salla, Gauto e Alvarez (2006) já haviam começado a refletir sobre a contribuição dessas formulações para o caso brasileiro:

O Brasil não apenas apresenta diversas tendências apontadas por Garland crescimento do encarceramento, maior severidade nas penas

\footnotetext{
${ }^{3}$ Algo como um estado de bem-estar penal.

${ }^{4}$ Para aqueles familiarizados com o estudo, ficará clara a minha dívida com esta síntese no mapeamento do debate sociológico sobre a punição.
} 
criminalização da miséria, etc. - como ainda é afetado por expressivos dilemas na recomposição de seus aparatos de justiça criminal em meio ao processo de democratização vivido nas últimas décadas.

De fato o fenômeno do maior encarceramento, como já dito antes, apresenta seus exemplos por aqui, mas até que ponto um aumento da severidade nas penas também está presente e em que medida a criminalização da miséria é uma tendência (em oposição a uma ideia de permanência)? Quanto à primeira, analisando a produção das leis aprovadas em segurança pública e justiça criminal no Congresso Nacional brasileiro, Campos (2010) encontrou tanto leis que aumentavam a severidade das penas e/ou que ampliavam os tipos penais, quanto leis que visavam a efetivar direitos, despenalizar condutas ou estabelecer penas alternativas, além de leis que continham em si as duas coisas. Já a criminalização da miséria, quase toda a tradição sociológica de que falei no começo desse capítulo, ressalta que este é um problema fundamental do Brasil desde sempre. Como sugeriu Campos (2008) é preciso continuar problematizando essas formulações para pensar o caso brasileiro.

\subsection{Estudos sobre crime e violência no Brasil tendo os Conselhos Comunitários de Segurança como objeto}

É possível identificar as duas vertentes dessa linhagem - a vertente dos direitos e a vertente da sociologia da punição - nos poucos estudos teoricamente orientados existentes sobre os Conselhos Comunitários de Segurança. Em primeiro lugar, a preocupação com a desigualdade e formas hierárquicas de atribuição de direitos estão no cerne desses estudos.

Em Miranda (2007) a questão dos direitos no Brasil é enfatizada a partir da teorização de José Murilo de Carvalho que descreve a distribuição dos direitos civis entre os cidadãos brasileiros segundo critérios hierárquicos:

[Há os cidadãos] de primeira classe (doutores); os de segunda classe (os cidadãos simples) - que estão sujeitos aos rigores e aos benefícios da lei; e os de terceira classe (os "elementos"), ou ignoram seus direitos ou os têm sistematicamente desrespeitados por outros cidadãos, pelos governos e pela polícia (Ibidem, p. 427).

E também a partir de Kant de Lima $(1997,2004)$ pois no Brasil, o discurso jurídico-político em favor da igualdade se oporia às práticas cotidianas que são hierárquicas - o paradoxo legal brasileiro -, e desfavoreceriam as interações plurais dificultando que se construam espaços verdadeiramente 
públicos pautados pelo debate racional e construção de consensos. Por isso as formas de intolerância à diferença se manifestariam. Essa seria a fonte da estigmatização de certos grupos sociais nos espaços das reuniões:

No primeiro caso [intolerância à diferença], observa-se que, em áreas cuja presença predominante é de representantes das classes média e/ou alta, são comuns os comportamentos e discursos que visam ao isolamento e à exclusão dos grupos mais pobres, com uma clara estigmatização dos moradores de favela (MIRANDA, 2007, p. 435).

A interpretação sobre os direitos de Moraes (2011) por sua vez, filia-se mais proximamente à interpretação de DaMatta de que, diferentemente da Europa Ocidental e dos Estados Unidos onde teria prosperado a ideia de cidadania como um papel universal capaz de dar fim a leis particulares e privilégios da nobreza e do clero, no Brasil, a comunidade se formaria por indivíduos vinculados a famílias, parentelas e facções. Da diferença entre o indivíduo e a pessoa, decorreria a existência de muitas concepções de cidadania, operando de formas complementares entre si.

A palavra "cidadão" é recorrentemente usada, no Brasil, sempre em situações negativas, especialmente para marcar a posição de alguém que esteja em desvantagem. No Brasil, enunciar ser "cidadão" é estar sujeito ao tratamento universalizante e impessoal, e é justamente o contrário de ser "reconhecido" numa situação de conflito ou disputa. O ritual do reconhecimento, afirma o autor [DaMatta], humaniza e personaliza as relações formais, permitindo a "devida" classificação dos atores envolvidos na querela e na hierarquia social. (MORAES, 2011, p. 66).

Nessa chave interpretativa que enfatiza a necessidade das relações pessoais, Moraes (2011) analisa que, mesmo que as reuniões dos Consegs sejam públicas e, portanto, abertas a abrigar qualquer pessoa que dela queira participar, são espaços de inclusão e exclusão, onde cada indivíduo busca enfaticamente ser reconhecido pelos demais participantes como um ator desejável. A análise destaca os momentos antes e depois das reuniões em que os participantes cercam as autoridades, reivindicando uma proximidade particularizada com o poder e também a formação de pequenos grupos que falam ao pé do ouvido, negociando posições e adesões e, sobretudo, mostrando relações e um sentido de pertencimento. Esse comportamento seria fruto da necessidade de se evitar ser apenas um cidadão e obter privilégio:

Ser reconhecido por um policial numa situação de necessidade era não só um desejo, mas um importante capital político acumulado, que poderia 
resultar numa forma de não ser tratado segundo os rigores da lei, impessoais e duras. Numa outra passagem, como bem apontou a líder comunitária ao relatar sua atual relação com a polícia a partir de sua participação nas reuniões do conselho comunitário de segurança: "se a gente liga, a gente tem uma certa atenção; se a gente precisa de alguma coisa, da assinatura deles, é na hora que eles dão", o que pode indicar um dos efeitos que esta aproximação pode gerar ao falarmos do contexto brasileiro (Ibidem, p.66).

Para Galdeano (2009), a interpretação da questão dos direitos é mais nuançada e não é tão calcada na tradição sociológica da hierarquia. No espaço dos Consegs haveria a exclusão dos direitos civis daqueles considerados "agentes da insegurança" (Ibidem, passim). Ainda que em termos teóricos Galdeano formule a segregação em termos não econômicos, sua descrição passa pelos direitos sociais. A nomeação desses agentes da insegurança passa pela segregação socioeconômica e se condensa na frase "eu sou cidadão de bem e pago meus impostos" que geralmente se segue pela afirmação dos direitos de quem paga imposto em detrimento dos direitos daqueles que supostamente não o fazem. A segregação também se daria no plano político, na exclusão e tratamento diferenciado dado aos participantes de menor poder aquisitivo ou percebidos como associados de alguma forma com os agentes da insegurança. Na pesquisa empírica ela também revelou a representação da violência por parte dos ativistas e defensores de direitos humanos que também nomeariam de forma estigmatizada o outro (o policial violento, por exemplo). Mas nos Consegs, especificamente, esse outro lado da representação da violência seria segregado e retirado (ou retirar-se-ia) de cena:

O que as interações nos Consegs mostraram é que esses espaços acirram esquemas de significação da violência e nomeação do perpetrador que articulam preconceitos de classe, ocupação social, gênero, etnicidade e, às vezes, religião. O panorama geral desses encontros são relações intolerantes, discursos que aprofundam esquemas de diferenciação social e segregação política. O maior domínio da cena pública nesses encontros tende a ficar a cargo dos moradores com maior capital de relações com os policiais e os técnicos das subprefeituras, em contraste com aqueles que revelam maior capital em termos de ativismo ou apropriação da linguagem dos direitos humanos. Por outro lado, a linguagem dos direitos tende a se mesclar com discursos que tendem a negligenciar os direitos dos outros, e moradores de todas as classes sociais parecem utilizar explicações duais para demandar por seus direitos específicos, entre os quais o direito à segurança e o direito dos jovens infratores (GALDEANO, 2009, p.11).

Diferentemente de Caldeira (2000), que com o conceito de cidadania disjuntiva explicita a tensão implicada em um discurso que defende os direitos sociais dos mais pobres, mas nega a uma 
parcela considerável desses pobres, os direitos civis, Galdeano (2009) não dá importância para solidariedades sociais entre classes eventualmente expressas pelos moradores nos Consegs:

...ainda que todos concordem que o problema social acaba nas mãos da polícia e que a polícia enxuga gelo em um contexto de problemas estruturais (GALDEANO, 2009, p. 12, grifo meu).

Tanto em Galdeano (2009) quanto em Moraes (2011) a questão da demanda por lei e ordem colocada na sociologia da punição aparecem. Retomando o que já foi descrito, na sociologia da punição o paradigma de lei e ordem descreve uma preferência por ações intolerantes: de lei punições mais duras contra crimes graves e tolerância zero mesmo a crimes de menor potencial ofensivo - e ordem, em que o espaço público deve permanecer limpo e ordenado e as condutas sociais devem ser controladas e disciplinadas. Lei e ordem andam juntas e em algumas interpretações é quase como se demandas tão diversas quanto a adoção da pena de morte, pedido por policiamento ostensivo em lugares determinados, reclamações por falta de iluminação pública ou conflitos a respeito de perturbação do sossego público fossem parte de um continuum, com esses problemas diferindo em gradação, mas não em natureza. Essa aproximação, pelo menos entre parte desses elementos, está implícita no trecho abaixo:

Comparativamente, não ouvi de nenhum morador de Sapopemba opiniões que apoiam a pena de morte, ainda que haja aqueles que reivindiquem ações duras das polícias, como é o caso de uma diretora de escola pública que pedia o apoio policial para conter jovens "rebeldes" (GALDEANO, 2009, p.12, grifo $\mathrm{meu})$.

A leitura de lei e ordem como uma reação às inseguranças de viver em uma grande cidade da modernidade tardia ou num mundo neoliberal, fica mais evidente no seguinte excerto:

Já é noção recorrente entre os pesquisadores da área da violência que o sentimento de medo e insegurança é o responsável pelo apoio e mesmo demanda da população a práticas autoritárias (GALDEANO, 2009, pg. 9).

Essa leitura é fundamental na reflexão porque explica uma clivagem social em relação às percepções sobre crime e violência em que o perpetrador é sempre o outro irreconhecível: o monstro criminoso de um lado e o policial violento de outro. Essas concepções transformar-se-iam em barreiras ao consenso e à possibilidade de formular soluções para os problemas da 
criminalidade. Ao interpretar a postura dos cidadãos no Conseg, Galdeano não problematiza a importação da teoria supondo que aqui ocorreram os mesmos processos que nos EUA, Inglaterra, França etc.:

Desde a sua criação até hoje, a existência dos Consegs coincide com mudanças importantes na concepção da segurança púbica como um direito, bem como com paradoxos nos campos das práticas e das mentalidades (Ibidem, pg. 67).

Em Moraes (2011), a leitura da sociedade de lei e ordem tem mais uma consequência: ela explica porque na reunião dos Consegs aparecem tantas demandas aparentemente alheias ao tema da segurança e relacionadas ao ordenamento e manutenção do espaço público:

Na realidade, tudo faz sentido e demonstra percepções de desordem por parte dos participantes: do gato do telhado ao barulho do exaustor. Não são apenas os altos ou baixos índices de violência registrados nas ocorrências policiais que estão em jogo, mas os fatos que motivam o medo das pessoas nas grandes cidades e as fazem recorrer à instituição do estado capaz de "fazer cumprir" a lei, de garantir obediência diante da resistência: a polícia (MORAES, 2011, p. 153).

De fato, a construção do sentimento de insegurança por parte de uma comunidade é, dentre outros fatores, reflexo de sua percepção acerca do investimento do governo na manutenção do espaço público, onde a ausência de conservação mostra-se um fator importante para a elevação do sentimento de medo e risco, mesmo que os problemas identificados não se traduzam necessariamente em "casos de polícia" (Ibidem, p. 235).

Assim, a reclamação do barulho do exaustor faria parte da mesma cadeia de racionalidade que exacerba o incômodo em relação aos moradores de rua, a preocupação com a conservação de ruas e praças, consumo de drogas, tráfico, furtos, roubos e homicídios.

Em comum, as análises de Miranda (2007), Galdeano (2009) e Moraes (2011) demonstram que há diferentes concepções de direitos e cidadania em disputa nos Consegs, seja entre atores diferentes ou até mesmo em momentos diferentes. Mas as consequências que tiram disso são diversas. Para Galdeano, as diferentes noções de insegurança em disputas através das tramas simbólicas, impedem o consenso no campo das políticas ou soluções na área de segurança pública. Miranda, a partir de uma leitura habermasiana (GURZA LAVALLE, 2011) da participação, espera que 
a prática continuada das disputas no espaço público com o tempo venha a produzir cidadania e minorar as concepções hierárquicas de direitos. Moraes por sua vez, acredita que as concepções hierárquicas de direito já estão sendo relativizadas nos espaços do Conseg, uma vez que a forma de circulação da palavra produz inversão de hierarquias entre autoridades e os demais membros da sociedade, esses últimos, representados de forma plural nos Consegs, onde até mesmo o grau de vulnerabilidade de um indivíduo pode ser o indicador de sua legitimidade. Para compreender seus ganhos e limites, é preciso observar um pouco melhor cada um desses diagnósticos.

Galdeano (2009) investiga "os distintos significados da violência [que] se convertem em discursos disputados por atores que contrastam diferentes representações sociais" (p. 09). A disputa desses significados da violência impediriam consensos mínimos para "soluções concretas de como resolver os problemas" (Ibidem, p. 11). Conectando esse cenário de disputas à problemática de lei e ordem, o diagnóstico é de que:

O cenário atual é, portanto, paradoxal. A participação da sociedade civil na discussão dos problemas locais foi ampliada, ao mesmo tempo em que as insatisfações de parte da população aumentaram com demandas por punições mais severas cujo horizonte é restaurar a segurança, a lei e ordem; ainda que essa possa não ser uma tendência geral (Ibidem, pg. 12).

Nesse diagnóstico, a existência das reuniões dos Consegs estão associadas positivamente ao aumento das demandas por punições, os Conseg "acirram esquemas de significação da violência e nomeação do perpetrador que articulam preconceitos de classe, ocupação social, gênero, etnicidade e, às vezes, religião" (Ibidem, p.11). A consequência lógica é que quanto mais Consegs, mais demandas por punições mais severas.

Mesmo compartilhando alguns supostos latentes com Galdeano - a emergência da sociedade de lei e ordem no Brasil e o caráter hierárquico das relações sociais -, Moraes chega a um diagnóstico final diametralmente oposto. Nesse espaço criado pelo Estado, Moraes (2011) defende que o apetite regulatório dos órgãos da segurança pública que pretendem domesticar a participação para que a sociedade seja, sobretudo, uma fonte de informação através das denúncias, é contornado pelos atores civis, seja o público em geral ou membros da diretoria que inventam, aprendem e reinventam a participação. Se por um lado a proximidade com atores estatais é desejada e confere capital político e social aos membros, especialmente presidentes e diretores que demandam símbolos de seu status (carteirinhas, crachás, cartões etc.), os atores são capazes de, 
através da circulação da palavra e dos discursos de cidadania, reposicionar hierarquias no momento da reunião.

Afinal, uma "reunião boa" é aquela onde a "autoridade" que se faz presente fala menos, ouve mais, ocupando-se de atender ao máximo os presentes e respondendo a todos dentro do possível. Assim, monopolizar a palavra, fazê-la prisioneira de uma única razão discursiva, qualquer que seja, aparece como uma expropriação do ato de participar, que arrisca-se não apenas ao descrédito do falar demais indesejável e improdutivo, mas também a receber efusivas e imediatas manifestações corporais e discursivas de reprovação e censura coletivas. (MORAES, 2011, p. 130)

Estar "frente a frente" com a "autoridade" que escuta e responde, os torna, neste ritual, cidadãos "poderosos", satisfeitos por sua oportunidade de falar. É a oralidade e a circulação da palavra neste ritual de participação chamado reunião do conselho comunitário de segurança onde é produzida uma espécie de simetria entre atores que são, por definição e por razões óbvias, desiguais (Ibidem, 2011, P. 216).

Essa inversão da autoridade ganharia força a partir da legitimidade dos atores que agregam importância à sua fala a partir de hierarquias diversas:

...de antiguidade naquela região ("Eu moro na Lagoa há 40 anos!"), segundo o grau de vulnerabilidade que aquele ator social acumula ("Sou da Cruzada São Sebastião, mas não sou bandido!"), segundo a classe social de quem reside na área da 23a AISP ("Eu moro no Leblon! É o IPTU mais caro da cidade"), segundo sua aproximação com as esferas do estado ("Sou assessor do Deputado! Ele garantiu que isso será feito!") e segundo a sua assiduidade nas reuniões ("É a primeira vez que venho nessa reunião...") (MORAES, 2011, p.138).

Tudo isso é possível porque as reuniões são rituais. Em princípio, a comparação é com o carnaval de DaMatta (1997) que permite a inversão das hierarquias e, mesmo em meio ao dissenso, impedir o rompimento da unidade social. Mas, de forma diferente, a unidade social e manutenção do status quo não seria a consequência última do ritual da reunião na análise de Moraes. Quando a autoridade é impelida pela dinâmica do ritual a responder, "de bate pronto", sem preleções ou "aula de cidadania" aos presentes, ela estaria realizando uma forma de prestação de contas, accountability em tempo real. 
Ao ser provocado por uma pergunta, reclamação ou demanda da comunidade presente, sua resposta "de pronto", imediata e precisa ao pleito apresentado é uma das características fundamentais observadas e que geram, quase que automaticamente, um sentimento de satisfação entre os participantes presentes (Ibidem, p. 149).

É a eficiente circulação da palavra, que é um bem escasso cuja distribuição cabe ao presidente, da forma mais ampla e diversificada possível, especialmente entre os participantes da plateia, que empresta legitimidade e status políticos ao conselho e garante a sua continuidade:

...o número (e a "qualidade") das pessoas presentes deve ser suficiente para que não pareça esvaziada e desprestigiada e não tão grande que não permita que os presentes façam uso da palavra no intervalo de duas horas, tempo destinado para a realização da reunião. Não se trata apenas de um aspecto logístico, mas por trás dele reside uma ideia de representatividade política dos participantes desse encontro e dos seus perfis, trazendo mais ou menos prestígio, status e poder para a reunião do conselho. (Ibidem, pg. 207)

Traduzindo essa interpretação em termos de mecanismo, é a necessidade de garantia de legitimação e continuidade do espaço e, consequentemente, do capital político e social que confere ao seu presidente e membros da diretoria, que garante o aspecto mais igualitário da reunião, ou seja, a distribuição da palavra de forma isonômica, permitindo a manifestação plural e a possibilidade de legitimação a partir de hierarquias não usuais, tal como o grau de vulnerabilidade de um indivíduo. A conclusão de Moraes é que as autoridades em geral estariam se abrindo em relação à participação, o que não é nada banal, especialmente em relação à polícia, uma instituição que tem uma lógica militarizada, fechada e que percebe a segurança pública ainda como questão de segurança nacional.

Sua emergência [dos Conselhos na área de segurança] vincula-se aos processos políticos que possibilitaram a abertura e a distribuição da palavra sobre o que antes encontrava-se prisioneiro da "razão de estado". Sua construção assenta-se na democratização mesma do falar sobre segurança pública num espaço (de uso) público, que não está mais restrita ao léxico já conhecido e compartilhado pelas instituições policiais (MORAES, 2011, p. 284). 
A disposição das autoridades e dos participantes em "falar, ouvir, escutar e responder" (MORAES, 2011, passim) é parte de um sistema de dádivas que estruturaria as relações em sociedade, manifestação de solidariedade social, que seria possível mesmo em um contexto onde a presença e do Estado tenha se tornado essencial para a manutenção das garantias e ordem sociais. O sistema operaria e distribuiria não somente bens e serviços, mas, sobretudo, confiança, lealdade e solidariedade.

Já para Miranda (2007), os Consegs seriam (ou deveriam ser) o espaço público onde sociedade e Estado expressam suas opiniões racionais a serem submetidas ao escrutínio e crítica pública. A constituição do espaço público no Brasil, porém enfrentaria duas grandes barreiras: de um lado, as hierarquias que, rejeitadas no discurso político e jurídico, estruturam as relações cotidianas e, de outro, a privatização do espaço público "entendido como aquele que é controlado pelo Estado, de acordo com "suas" regras, e que pode ser apropriado particularizadamente".

Tanto os conceitos de espaço público quanto o de arena pública apresentam limitações para pensar a sociedade brasileira, tendo em vista que ambos tomam como referência sociedades em que a cidadania e o respeito aos direitos do cidadão foram contemplados não apenas no plano das normas, leis e regras, mas também está presente em diferentes dimensões da vida social. [...] Tal cenário não pode ser observado no Brasil (MIRANDA, 2009, p. 425).

A sociedade civil, verdadeira, é percebida como autônoma em relação ao Estado. Por exemplo: a exigência da constituição de conselhos comunitários de segurança por parte da administração federal como condicionante para repasses de verbas ${ }^{5}$, nos moldes de outras áreas de política como saúde e assistência social, poderia comprometer o caráter democrático desejado para os Consegs. Melhor seria se fosse uma demanda dos movimentos sociais e não indução e assim evitando os vícios de outras instâncias políticas:

Os conselhos gestores de políticas públicas devem funcionar como espaços públicos com composição plural e paritária, cujos instrumentos privilegiados de resolução de conflitos são o diálogo e a publicidade, que os diferencia de instâncias políticas onde imperam as trocas de favores e a cooptação pelo poder público (Ibidem, 2009, p. 431).

\footnotetext{
${ }^{5}$ A tentativa de indução federal para a criação de conselhos na área de segurança nos estados e municípios deu-se a partir da década de 1990, ou seja, foi posterior à criação dos Consegs do estado de São Paulo que são o objeto empírico desse estudo e existem desde 1986.
} 
Um dever ser muito difícil de colocar em prática no Brasil "oligárquico, autoritário e patrimonialista" (ibidem, p. 428). Mas a solução para esse mal estaria na própria prática da participação que com o tempo deveria fazer surtir seus efeitos democratizantes:

...cada experiência de classe/grupo/categoria produz uma visão de mundo, e que essas visões constituem a riqueza das sociedades. Somente assim, podese pensar que a democracia deve garantir o respeito às diferenças individuais e à pluralidade, como um estímulo à criação de espaços para a participação de sujeitos cada vez mais receptivos. (MIRANDA, 2009, p. 418. Grifo meu).

Decorre daí que o fortalecimento dos atores civis é um desdobramento possível da experiência dos Consegs, apesar da participação do Estado:

Embora o vínculo com o Estado permaneça, observa-se uma dimensão que enfatiza a organização e o fortalecimento dos próprios atores da sociedade civil e de sua articulação, e a democratização das instituições de segurança, tradicionalmente mais refratárias à interação com a população. (MIRANDA, 2009, p. 432)

Ou seja, em que pesem as práticas sociais hierarquizantes no Brasil, Miranda vê a constituição dos conselhos de segurança pública um avanço em uma área que até então estava vedada à participação. Sua previsão é que as interações cotidianas entre atores plurais e heterogêneos - desde que haja a inclusão de atores plurais e heterogêneos - farão com que as diversas concepções de cidadania sejam confrontadas para a construção de uma "cultura mais democrática", como um aprendizado cívico.

\subsection{Os estudos sobre participação: a abordagem da sociedade civil e o polity approach}

O Consegs como objeto não têm presença relevante na literatura sobre participação. Uma busca na base de dados online Scielo com a palavra Conselhos ${ }^{6}$ resultou em 226 resultados de artigos. Desses, 95 entradas não se referiam aos conselhos gestores; 59 referiam-se a conselhos

\footnotetext{
${ }^{6}$ Buscas com os seguintes termos ou expressões não retornaram nenhum resultado: "Conseg"; "Conselhos Comunitários de Segurança" e "Conselho Comunitário de Segurança”. Busca realizada em maio de 2012.
} 
gestores na área de saúde; 36 eram análises de conselhos gestores em geral; 17 eram sobre conselhos na área de educação. Os 19 restantes eram artigos em outras áreas de política tais como meio ambiente e segurança alimentar. Não houve nenhuma referência a conselhos na área de segurança. Nas principais coletâneas sobre participação os Consegs também não aparecem (DAGNINO 2002, AVRITZER 2004, GURZA LAVALLE 2011a e PIRES, 2011).

O único trabalho encontrado que utiliza a literatura da participação como chave para analisar os Consegs foi o de Miranda (2009). Em sua análise (2009) Miranda filia-se à família de argumentos que Gurza Lavalle (2011b) chama de abordagem da sociedade civil. A abordagem da sociedade civil parte da diferenciação dicotômica entre Estado e sociedade. Ao ser aplicada aos espaços participativos que emergiram no Brasil a partir da década de 1990 (especialmente a experiência do Orçamento Participativo e dos Conselhos Gestores de Políticas Públicas), esta abordagem atribui aos indivíduos e organizações civis o papel e a capacidade de controlar o Estado, torná-lo mais virtuoso e eficiente. Os espaços participativos emergentes seriam então o espaço onde o Estado poderia ser controlado e corrigido pela sociedade civil. Nessa suposta dinâmica de funcionamento, deduzida de uma inspiração habermasiana, a sociedade civil é descrita como independente e autônoma, ignorando-se os processos de mútua constituição entre Estado e sociedade (GURZA LAVALLE, 2011b). Em Miranda, há algum espaço para desconstruir a imagem idealizada da sociedade civil, tanto é que ela usa essa categoria para incluir "grupos conservadores, muitas vezes esquecidos nas investigações" (Miranda, 2009, p. 420), que nesse caso são os frequentadores dos Consegs, ou parte deles. De qualquer modo, a sociedade civil é concebida por ela como necessitando de uma separação demarcada em relação ao Estado para que seja capaz de controla-lo e assim produzir o encaminhamento adequado dos problemas de exclusão e desigualdade.

Na crítica de Gurza Lavalle (2011b), ao separar Estado e sociedade, essa abordagem "acabou por impulsionar caracterizações despolitizadas da sociedade civil em sentido de eclipsar suas relações com as instituições políticas e bloquear a reflexão sobre a própria política na sociedade civil” (Ibidem, p. 207). Como alternativa, reivindica fazer parte de uma linhagem do polity approach, inaugurada por Sckockpol. Os autores filiados ao polity approach argumentam que o poder de influenciar políticas públicas das organizações sociais é dependente da capacidade de atores societais $^{7}$ e estatais em construir pontes que atravessem a divisão público-privado para formar coalizões amplas o suficiente para influenciar uma determinada área de política, seja na forma de mudanças incrementais, seja na forma de mudança de trajetória.

\footnotetext{
${ }^{7}$ De modo geral, os formuladores da crítica da abordagem da sociedade civil evitam usar a expressão sociedade civil para caracterizar esses atores em suas descrições.
} 
A vertente do neo-institucionalismo nas ciências sociais tem desenvolvido nos últimos anos alguns conceitos que se apresentaram muito férteis para pensar a política, especialmente a política pública. Conjunturas críticas (COLLIER, 1991), encaixe institucional (SCKOCKPOL, 1992), embedded autonomy (EVANS, 1995) e dependência da trajetória (PIERSON, 2004) são alguns desses conceitos que, embora não tenham a pretensão de formulações de leis gerais (lawlike), ajudam a explicar determinadas áreas de política pública e da ação de atores políticos. Comum entre todos é a ideia de que as instituições políticas e desenho institucional têm certo grau de autonomia e não são unicamente o resultado das lutas travadas na sociedade (SCKOPOL, 1992).

Formulado por Sckockpol (1992), o conceito de encaixe institucional descreve a capacidade de um determinado grupo de interesse de se imbricar nas instituições administrativas relevantes para uma determinada área de política. Essa capacidade pode ser fruto do acaso, resultado não previsto das próprias instituições ou ainda deliberadamente construída. Se for construída, Houtzager (2003) a chamará de arquitetura do encaixe institucional. Gurza Lavalle, Acharya e Houtzager (2005), dando continuidade às reflexões do polity approach, pensam a arquitetura do encaixe institucional no tempo. Nos momentos extraordinários de inovação institucional, como as transições políticas e os momentos de construção do Estado, os atores mais bem posicionados teriam capacidade de arquitetar seu encaixe institucional e proteger seus interesses futuros. A cada nova rodada de negociações, as vantagens tendem a se sedimentar pela "repetição de ações exitosas ou fracassadas" (GURZA LAVALLE, 2011b, p. 218). Esses atores bem posicionados estariam institutionally embedded, ou institucionalmente arraigados. A ideia de institutionally embedded foi inspirada em formulação de Evans (1995).

Evans (1995) comparou a política desenvolvimentista de três países a partir dos anos 70: Coréia, Brasil e Índia. Houve um primeiro momento em que esses Estados, numa postura desenvolvimentista, aliaram-se a empreendedores privados numa grande coalização para impulsionar os respectivos setores nacionais de tecnologia da informação. O maior ou menor sucesso de cada caso estudado teria sido determinado pela presença de um fator que ele deu o nome de embedded autonomy, uma burocracia estatal altamente qualificada como descrita por Weber, mas não isolada da sociedade e sim encravadas em um conjunto concreto de laços sociais que vinculariam o Estado à sociedade e proporcionando os canais institucionalizados para a contínua negociação e renegociação de objetivos e políticas.

Se o conceito de embedded autonomy enfatiza a ação do Estado na sociedade, institutionally embedded, foca a sociedade penetrando o Estado. Ambos levam em consideração a agência 
(agency) dos atores, considerando ao mesmo tempo os constrangimentos institucionais que os limitam.

\subsection{Para onde ir}

Nesse ponto, volto ao começo para retomar a inspiração de Garland (1993) sobre como pretendo inserir este estudo no diálogo com as pesquisas que o precederam:

Minha intenção é portanto, trabalhar cada uma das tradições teóricas existentes, uma de cada vez, tratando cada uma não como um modelo rígido ou descrição totalizante, mas como fonte de perspectivas específicas e interpretações parciais. (GARLAND, 1993, pg. 15)

Em quais pontos as formulações mais consistentes sobre os Consegs escritas até agora podem ser revisadas, complementadas ou nuançadas a partir do olhar de um lugar diferente? Esse olhar diferente é o olhar do neo-institucionalismo que ora servirá de inspiração mais livre para apontar que regras de funcionamento importam, ora será utilizado de forma mais específica, a partir do conceito de institutionally embedded. Esses recursos serão utilizados na construção de um argumento cumulativo que se desdobra em passos. Alguns passos são descritivos, visam a nuançar, complementar ou desafiar os diagnósticos atuais. Outros são explicativos e o objetivo é compreender por que os Consegs são como são.

a) Em primeiro lugar serão revistas as regras formais de funcionamento dos Consegs, as circunstâncias de criação desses espaços participativos e as tentativas realizadas por legisladores estaduais de ampliação das atribuições dos mesmos (capítulo 3). O objetivo é enfatizar os constrangimentos à atuação dos atores societais e verificar a hipótese de que esses constrangimentos podem ser explicados, pelo menos em parte, pelo posicionamento desses atores em um momento de grande inovação institucional: o período de redemocratização e a primeira legislatura estadual eleita após 1964.

b) Em segundo lugar (capítulo 4, item 4.1), pretendo investigar qual a relação entre os atores da política formal com os participantes dos Consegs. Será que é a distância das relações supostamente patrimonialistas com representantes do Estado que garante "o encaminhamento adequado dos problemas de exclusão e desigualdade social" como pretende Miranda (2009)? Ou então, será que a reunião dos Consegs colocaria em movimento um sistema de dádivas, distribuindo bens, serviços, confiança, lealdade e solidariedade como formulado por Moraes (2011)? O conceito de institutionally embedded pode ajudar a pensar essa questão de um terceiro ponto de vista. 
Poderia ser o caso de a ligação dos membros do Conseg com representantes políticos -, especialmente aqueles com atuação mais territorializada como tendem a ser aquela dos vereadores -, ajuda a explicar o sucesso dos Consegs em permanecer uma instituição com capilaridade (aproximadamente 70 Consegs ativos) na cidade de São Paulo e. Para construir um quadro dessas relações entre Conseg e representantes, serão investigadas as atuações dos vereadores da cidade de São Paulo nos últimos dez anos que envolviam os Consegs e a relação inversa: dos membros dos Consegs na Câmara Municipal. Em relação à proposição de Moraes (2011) a diferença desta hipótese é que: mais importante do que a suposta manifestação do sistema social de dádivas entre membros dos Consegs e autoridades, é a relação entre membros e os atores da política institucional que ampliam a legitimidade dos Consegs, relação esta que é racional e baseada em interesses mútuos: de um lado o voto, de outro lado, um séquito de defensores no poder legislativo.

c) Em terceiro lugar (capítulo 4, item 4.2), pretendo verificar se as "relações intolerantes, discursos que aprofundam esquemas de diferenciação social e segregação política" que inegavelmente aparecem nos Consegs de tempos em tempos, são realmente capazes de acirrar "esquemas de significação da violência e nomeação do perpetrador que articulam preconceitos de classe, etnicidade etc." como descreve Galdeano (2009). Essa questão será pensada a partir das evidências prévias da literatura, de informações colhidas nas reuniões observadas, bem como dados secundários. Além disso, para pensar os Consegs em termos de direitos e desigualdades, segregação e solidariedade social, será proposto um olhar complementar dos Consegs. Haveria algum aspecto em que as reuniões poderiam ser consideradas o oposto da segregação (ainda que o aspecto da segregação social esteja presente)? É razoável supor que, ao permitir uma interface com a administração pública em contextos onde moradores tendem a ter menor capital político e social, os Consegs possam alavancar demandas enquanto em contextos de afluência e proximidade com os circuitos do poder eles podem ser menos relevantes. Para demonstrar como os participantes dos Consegs mais ricos têm mais recursos fora do Conseg, serão mostrados dados sobre ações judiciárias envolvendo seus membros. Para testar a hipótese de que há aspectos em que os Consegs podem ser o oposto da segregação, será comparado o grau de satisfação dos moradores entre os diferentes distritos para verificar se alguma variável, especialmente de renda, é capaz de explicar um nível maior ou menor satisfação nas interações nesses espaços. Em termos mais amplos, a hipótese é que nos Consegs se expresse de alguma forma uma lógica semelhante àquela que Teresa Caldeira chamou de democracia disjuntiva: em que os direitos sociais e políticos são razoavelmente legitimados, e que há diminuição das desigualdades no tocante a esses direitos; mas os direitos civis permanecem enfrentando oposições, ainda que não haja nenhum fator que sustente a piora nesse quadro. 
d) Se Moraes (2011) estiver certa e as demandas contra o barulho do exaustor e o gato em cima do telhado forem manifestação de um desejo generalizado de lei e ordem gerados pela insegurança nas grandes cidades na modernidade tardia, a participação no Conseg não deve estar associada à ocorrência de crimes. Em termos teóricos, o que nos permite supor que as reclamações com manutenção de parques e barulho sejam sustentadas por um desejo crescente de lei e ordem no contexto brasileiro? Esse entendimento pode ser confrontado com a análise quantitativa amostral das atas de reuniões para verificar qual o papel da criminalidade na participação dos cidadãos no Conseg. A participação política tende a ser uma função positiva de escolaridade e renda. Qual o peso das variáveis criminais em relação às variáveis de renda e escolaridade na taxa de participação nas reuniões dos Consegs nos diferentes distritos da capital? Embora o argumento pareça opor-se completamente à interpretação de Moraes (2011), na verdade o que se pretende é nuança-la e mais uma vez problematizar os usos das formulações sobre cultura do controle para o caso brasileiro. Essa questão será abordada também no capítulo 4 (item 4.3).

e) Moraes (2011) estudou extensiva e profundamente, com observação participante, as reuniões dos Conselhos e realizou dezenas de entrevistas em dois Consegs de duas das mais importantes capitais do país: Rio de Janeiro e Brasília, ambos em regiões com grande concentração de pessoas com alto poder aquisitivo e escolaridade. Em um primeiro momento da pesquisa, a questão foi o quanto essa inversão da autoridade, especialmente no que diz respeito à autoridade policial, seria possível em locais que concentram população de baixa renda e menor escolaridade. Mas, como será demonstrado, em São Paulo foi observado um contexto em que há inversão de autoridade para representantes de órgãos não policiais e em que não existe inversão de autoridade para os representantes dos órgãos policiais, um resultado transversal, que independe do contexto da renda e escolaridade. No item 4.4 (capítulo 4), serão apresentados os dados da pesquisa que sustentam essa descrição.

f) No capítulo 5, pretendo amarrar as pontas dos passos descritivos e do passo histórico, propondo uma explicação institucional para explicar, ainda que parcialmente, por que os Consegs são como são.

Em outras palavras, a abordagem institucionalista será um referencial teórico para dialogar com os diagnósticos sobre os Consegs, tanto a respeito da questão dos direitos, quanto a respeito da questão da cultura do controle. Ainda quando desafia as interpretações correntes, as formulações aqui apresentadas não têm por objetivo negar essas interpretações, mas lançar luz a outras facetas e possibilidades alternativas de interpretação e explicação. 


\section{NOTA METODOLÓGICA}

\subsection{Um olhar descritivo sobre os Consegs}

Esse trabalho não pretende tentar fazer prevalecer uma construção teórica sobre outras, da mesma forma, não foram escolhidos métodos por critério de preferência. Se os estudos teoricamente orientados com os quais venho dialogando desde o capítulo anterior adotaram ou uma abordagem puramente teórica (MIRANDA, 2007) ou abordagens etnográficas de estudos de caso (GALDEANO, 2009; MORAES, 2011), um estudo de médio alcance deve ajudar a preencher uma lacuna importante. Em comparação com os estudos de caso, a presente abordagem é mais transversal abrangendo em alguns momentos a maior parte dos Consegs em funcionamento na cidade de São Paulo. Englobar a cidade de São Paulo como um todo e ao mesmo tempo restringir-se a ela é uma estratégia de pesquisa que permite medir alguns dos fatores importantes colocados pela pesquisa, especialmente no que diz respeito à abordagem institucionalista. Os Consegs analisados encontram-se em diferentes contextos sociais da cidade, que variam em termos de renda, educação e perfil de criminalidade. Esses diversos e variados casos estão todos submetidos às mesmas regras de funcionamento que emanam, sobretudo do governo estadual aos quais estão ligados, mas também são formatados por regras municipais, daí a necessidade da limitação pelo município ${ }^{8}$. A análise estatística das atas de reunião dos Consegs é uma das estratégias transversais da pesquisa, aquela que permitiu um maior alcance em termos de variação. As atas, porém têm sérias limitações. A fidelidade do que é relatado é uma função da paciência, disponibilidade ou habilidade do membro da diretoria elegido para a tarefa, que pode ser o primeiro secretário ou quem estiver disponível no momento. Em alguns casos a mão de obra pode ser escassa - em uma situação extrema ${ }^{9}$, foi-me solicitado em uma reunião a qual estive presente que cedesse minhas anotações de pesquisa para a composição da ata já que a secretária não havia conseguido chegar a tempo de tomar nota ${ }^{10}$. No extremo oposto, as reuniões do Conseg dos bairros de Santa Cecília e Penha colhidas na amostragem são tão longas em comparação com todas as outras que parecem ser transcrições extensivas de reuniões gravadas. $\mathrm{O}$ que ficou claro na primeira tentativa de amostragem ${ }^{11}$ e mais

\footnotetext{
${ }^{8}$ Uma outra abordagem possível e muito interessante, seria comparar Conselhos Comunitários de Segurança submetidos a diferentes regras de funcionamento. Não apenas seria uma empreitada de escopo maior do que em geral é possível desenvolver em um trabalho de mestrado, esse recorte só me ocorreu muito depois de o trabalho empírico ter avançado.

${ }^{9}$ Reunião observada: CONSEG Capão Redondo em 30 de julho de 2013 Associação Assistencial e Promocional do Capão Redondo.

${ }^{10}$ Fiz uma edição daquilo que poderia ser compartilhado e enviei posteriormente por correio eletrônico ao presidente, ele mesmo, segundo me contou, alfabetizado já depois de adulto.

${ }^{11}$ A primeira tentativa pretendia ser uma amostragem aleatória ordenada. Agradeço ao professor Rogério Bastos Arantes por apontar os problemas metodológicos quando do exame de qualificação.
} 
ainda depois de frequentar as reuniões, foi que a maior parte das atas não tinham o mesmo "teor de gordura" da reunião. Tudo aquilo que era percebido pelo redator como superficial, podia ser suprimido ou inserido de acordo com um critério qualquer. Inicialmente, o que mais me interessava - as representações, preconceitos, discursos, palavras e expressões utilizados pelos participantes, era justamente aquilo que era reproduzido da forma mais irregular e para o qual eu não poderia dar tratamento quantitativo confiável. Por outro lado, descobri que as manifestações substantivas pedidos específicos por serviços públicos e agradecimentos por demandas atendidas -, eram bastante regulares nas atas das reuniões dos diversos distritos. Ora, as atas das reuniões não são feitas para os pesquisadores, mas sim para registrar demandas e fazê-las avançar e, para isso, o documento oficial tem uma função importante. Ainda que seja discutível quais as motivações dos membros dos Consegs, que podem ser muito mais complexas do que simplesmente resolver problemas práticos da vida na cidade, é preciso que reafirmem constantemente a legitimidade desses espaços e uma ata contendo uma lista de demandas e agradecimentos específicos, passíveis de serem encaminhados e medidos é uma boa forma de mostrar que um Conseg está funcionando. Assim, os materiais das atas puderam receber tratamento quantitativo, mas é importante que se tenha em mente suas limitações e que sejam usadas com parcimônia.

Outra estratégia foi a observação de reuniões, nesse caso, um número muito mais limitado foi analisado, que permitiu abordar questões específicas. Inicialmente, a observação das reuniões era apenas uma metodologia acessória para balizar a interpretação das atas. Informações sobre a postura dos moradores, tom de suas falas, sutilezas e comportamento, ainda me interessavam e frequentar as reuniões mostrou-se mais produtivo do que inicialmente pretendido. Desse modo, as reuniões acompanhadas também receberam tratamento quantitativo para demonstrar a diferença entre o comportamento dos atores quando se dirigem aos representantes de órgãos policiais em comparação com quando se dirigem a outros representantes. As informações também foram utilizadas para ilustrar situações e argumentos em várias partes do trabalho.

Para tentar entender um pouco mais sobre os Consegs foi realizada uma pesquisa exaustiva no Diário Oficial do Município e do Estado de São Paulo. Essas informações foram utilizadas para reconstituir, ainda que parcialmente, as atuações de vereadores em relação aos Consegs e a participação de membros dos Consegs na Câmara Municipal. Complementarmente, acessei os dados da justiça eleitoral para saber em que lugares da cidade se concentravam os votos desses vereadores. Ainda com o material recolhido dos diários oficiais, descobri, quase que ao acaso, uma outra fonte de comparação entre os Consegs: o habito de recorrer à via judiciária no encaminhamento de demandas. 


\subsection{Um olhar explicativo sobre os Consegs}

Conforme anunciado anteriormente, a abordagem que pretendo utilizar e o conceito de institutionaly embedded considera que o posicionamento dos atores no momento da criação dos Consegs, tem uma importância fundamental para explicar os sucessos ou fracassos subsequentes ao tentarem influenciar políticas públicas nas suas áreas de interesse. Assim, também será utilizado o método de reconstrução histórica: do momento de criação dos Consegs e das posteriores tentativas de mudar as regras do jogo. Para isso foram utilizadas fontes secundárias da literatura disponível e também o material do Diário Oficial do Município, já citados anteriormente. Também foi utilizado um material publicado pela Secretaria de Segurança Pública com diretrizes para os membros dos Consegs: a Coletânea: legislação, normas e modelos e por fim foram seguidas as tramitações de leis estaduais sobre os Consegs na base de dados da Assembleia Legislativa do estado.

Nas próximas sessões exponho mais detalhadamente as fontes utilizadas e os dados coletados e o tratamento dado a cada um, retomando o propósito de cada qual e o momento em que foram utilizados.

\subsection{As fontes e tratamento}

\section{Diário Oficial}

A pesquisa no Diário Oficial - estadual e municipal - foi realizada usando-se o mecanismo de busca do website da Imprensa Oficial do Estado de São Paulo e foram utilizadas as palavras Conseg (singular e plural), Conselho Comunitário de Segurança (singular e plural) e ainda "Conseg's". Poucas ocorrências foram acrescentadas depois da primeira busca apenas com a palavra Conseg. A Imprensa Oficial do Estado é responsável pela publicação de ambos os periódicos e a busca foi realizada em conjunto. Depois de todas as notícias coletadas, foram criados dois bancos de dados separados: um para o município e outro para o estado. A limitação desse método foi que a busca por palavras chave só é possível para as edições de janeiro de 2003 em diante, sendo que os Consegs existem desde 1985. A pesquisa, tendo sido realizada em abril de 2013, inclui informações até este mês. Os dados do diário oficial foram utilizados para: a) ajudar a reconstruir a história institucional, especialmente no que diz respeito aos projetos de lei que tramitaram tanto na câmara municipal quanto na assembleia legislativa e que envolviam os Consegs (Capítulo 3); b) mapear as relações dos vereadores com os Consegs (Capítulo 4, item 4.1) e c) mapear a atuação dos membros dos Consegs pela via judiciária (Capítulo 4, item 4.2). 


\section{Justiça Eleitoral}

Foram colhidos dados de votação para saber se os redutos eleitorais dos vereadores estavam associados às regiões dos Consegs com os quais mostram relações. Para os vereadores que concorreram em 2012 foram utilizados dados dessa eleição para os demais foi utilizado o dado mais recente disponível. Essa informação foi utilizada para mapear as relações dos vereadores com os Consegs no capítulo 4 (item 4.1).

\section{Observação das reuniões}

Além de o material recolhido ter sido usado livremente para ilustrar ou esclarecer pontos específicos ao longo de toda a análise, o material de observação das reuniões recebeu um tratamento quantitativo. $O$ intuito era verificar se havia alguma diferença no tratamento dos membros dos Consegs quando se referem ou se dirigem a autoridades policiais em comparação com outros representantes do poder público. Se Moraes estiver certa, a própria prática das reuniões se repetindo no tempo é responsável pela emergência da abertura do Estado em relação à sociedade, o que é significativo especialmente em relação à polícia, e não haverá diferença quando os moradores se dirigirem a autoridades policiais e não policiais (item 4.4). $O$ banco de dados contém as seguintes variáveis:

- Elogio: agradecimento ou reconhecimento quando uma demanda foi atendida;

- Conquista da comunidade: são casos em que a atuação do gestor/servidor é ignorada quando se anuncia uma demanda atendida;

- Justificativa: segundo o cidadão, a não resolução de um problema pelos gestores/servidores são causados por fatores externos (comportamento das vítimas, direitos humanos, poder político, a má conduta de indivíduos isolados, falta de condições de trabalho, o comportamento incivil da população, condições socioeconômicas) ou são causados por uma decisão racional, bem fundamentada dos atores estatais, ainda que a decisão seja contrária ao desejo dos participantes do Conseg;

- Reclamação moderadamente contenciosa: em um tom agressivo ou irônico leve, acusação gravidade pequena ou indireta, ou ainda contradito em relação à fala da autoridade;

- Falas de confronto: fortemente agressiva, bate-boca ${ }^{12}$ ou acusação grave e direta.

\footnotetext{
${ }^{12}$ Uso a expressão bate-boca para destacar que essas são discussões em que, além de haver réplica, tréplica e assim por diante, têm um caráter mais agressivo em oposição a discussões que podem ser mais amigáveis.
} 
Foram observadas ao todo 15 reuniões. Tentei, dentro do que era possível, considerando a limitação de tempo e as dificuldades de deslocamento e de conciliar agendas, frequentar reuniões em regiões variadas da cidade. Com exceção do Mandaqui, foram observadas duas reuniões em cada Conseg visitado. A lista completa de reuniões acompanhadas está na tabela 1.

Tabela 1 - Lista das reuniões observadas

\begin{tabular}{|l|l|l|l|}
\hline Conseg & DP & Região & Data \\
\hline Sapopemba & 70 & Sudeste & $28 / 05 / 2013$ \\
\cline { 4 - 4 } & & & $25 / 06 / 2013$ \\
\hline Pari & 12 & Sudeste & $23 / 05 / 2013$ \\
\cline { 4 - 4 } & & & $27 / 06 / 2013$ \\
\hline Perdizes/Pacaembu & 23 & Oeste & $18 / 06 / 2013$ \\
\cline { 4 - 4 } & & & $20 / 08 / 2013$ \\
\hline Jardins/Paulista & 78 & Oeste & $10 / 06 / 2013$ \\
\cline { 4 - 4 } & & & $12 / 08 / 2013$ \\
\hline Itaim Bibi & 15 & Oeste & $11 / 06 / 2013$ \\
\cline { 4 - 4 } & & & $02 / 07 / 2013$ \\
\hline Liberdade & 1 e 5 & Centro & $19 / 06 / 2013$ \\
\cline { 4 - 4 } & & & $21 / 08 / 2013$ \\
\hline Capão Redondo & 47 & Sul & $30 / 07 / 2013$ \\
\cline { 4 - 4 } & & & $24 / 09 / 2013$ \\
\hline Mandaqui & 20 & Norte & $19 / 08 / 2013$ \\
\hline
\end{tabular}

\section{$\underline{\text { Atas de reunião }} 0^{13}$}

Cada reunião realizada em um Conseg gera uma ata que, após ser assinada pelo presidente e pelos membros natos, é encaminhada à Coordenadoria Estadual e é armazenada em sua versão impressa em arquivo próprio. Embora os Consegs existam desde 1986, estão disponíveis no arquivo

\footnotetext{
${ }^{13}$ Para obter os bancos de dados em formato Excel ou Stata, escrever para roberta.astolfi@gmail.com.
} 
apenas atas a partir do ano de $2010^{14}$. A partir de uma listagem das atas dos anos de 2010, 2011 e $2012^{15}$, separadas por Distrito Policial (cada Conseg da cidade de São Paulo corresponde a um DP), foram sorteadas inicialmente 108 delas para uma amostra estratificada. Foram excluídas sumariamente e resorteadas atas de reuniões comemorativas ou de eleição ${ }^{16}$. As atas deram origem a dois bancos de dados: o banco de dados de manifestações (reclamações ou elogios) em que a fala de cada morador corresponde a um caso e o banco de dados de reuniões, em que cada reunião é um caso. Para compor o banco de dados das manifestações houve uma perda de duas atas em cada um dos três primeiros estratos e um ata no estrato quatro ${ }^{17}$. Como o problema não parecia ser específico de um estrato, foram sorteadas novas atas para substituição. A perda foi em relação a reuniões cujas atas mostraram-se precárias demais, onde não era possível, por exemplo, identificar a pessoa que estava falando (se morador, presidente ou funcionário público) ou em alguns casos, a ata continha apenas a lista dos temas tratados ${ }^{18}$. Para a composição do banco de dados das reuniões houve perda de outra natureza - nem todas as reuniões tinham informação do número de representantes presentes o que era crucial para a análise pretendida. Desse modo, para este outro banco de dados foram recuperadas as atas previamente excluídas e sorteadas mais algumas novas. O banco de dados das manifestações foi utilizado para abordar a questão da desigualdade e segregação nos Consegs a partir da análise do grau de satisfação dos moradores mais pobres (Capítulo 4, item 4.2). Já o banco de dados das reuniões foi utilizado para a) complementar as informações sobre vereadores e Consegs (Item 4.1) e testar quais as variáveis que explicam a participação nos Consegs (item 4,3). As sessões seguinte até o final deste capítulo referem-se às variáveis e amostragem das atas especificamente.

\section{- Os Distritos e os Consegs}

Dos 93 distritos policiais da cidade de São Paulo (www.ssp.sp.gov.br), 90 deles tinham um Conseg que estava ativo no período de janeiro de 2010 a dezembro de 2012 (embora alguns poucos desses não tenham estado ativos durante todo o período) e um distrito atendia dois Consegs (5 DP:

\footnotetext{
${ }^{14}$ Há poucas atas de anos anteriores, não foram armazenadas sistematicamente. Durante a minha pesquisa a Coordenadoria dos Consegs estava desenvolvendo um protocolo de armazenamento e digitalização desse material e encaminhamento para o Arquivo do Estado de São Paulo.

${ }^{15}$ Agradeço a Yanilda González, candidata a PhD pela Universidade de Princeton, que cedeu a listagem das atas no período entre janeiro de 2010 e março de 2012. As demais atas foram listadas por mim com gentil ajuda da servidora Thais Costa Barbosa.

${ }^{16}$ Muitas vezes não há competição eleitoral e a eleição é feita por aclamação da chapa única. Nesses casos o processo de eleição não toma mais que algumas falas dos participantes e desse modo o restante da reunião decorre normalmente. Nesses casos as atas com eleição não foram excluídas.

${ }^{17}$ A mostra foi estratificada, como será exposto adiante.

${ }^{18}$ A lista completa e final das atas utilizadas, identificando data e distrito, está no apêndice B.
} 
Conseg Liberdade e Conseg Bela Vista/Bixiga). Desses 90 Consegs, foram excluídos da análise quantitativa os Consegs Liberdade (1 e 50 DPs), Bela Vista/Bixiga (5 DP), Ponte Rasa (24 DP) e Ermelino Matarazzo (62ㅇ DP), pois as reuniões abrigavam representantes de mais de um DP (dois representantes de duas delegacias diferentes) ou possuíam outras características que dificultavam excessivamente a sua identificação com um distrito policial único. Sem essa delimitação geográfica e demográfica seria muito difícil atribuir taxas de criminalidade para a área de cada Conseg, taxas essas de importância fundamental nas análises pretendidas.

\section{- Amostragem estratificada}

A opção por uma variável de renda para estratificação ${ }^{19}$ da amostra foi realizada em função da preocupação com a questão da desigualdade que será explorada no item 4.2 (capítulo 4). Para ordenar os dados em função da renda foram estudadas as variáveis disponíveis no Censo de 2010 (IBGE, 2011). Duas mostraram-se de interesse pela facilidade de uso: o número de responsáveis pelo domicílio com renda inferior a dois salários mínimos e o número de responsáveis pelo domicílio com renda superior a 20 salários mínimos. Foi utilizada a segunda opção. O número de Responsáveis pelo domicílio (RpD) com renda superior a 20 SMs foi então transformado em porcentagem em cada distrito e os distritos foram ordenados a partir daqueles com a menor porcentagem de RpDs com renda superior a 20 SMs e divididos em 4 estratos com 22 DPs cada um. A planilha de atas existentes para esses DPs selecionados nos anos de 2010, 2011 e 2012 foi ordenada, cada reunião recebeu um número e foram sorteadas 27 reuniões em cada estrato.

- As variáveis dependentes

As variáveis dependentes utilizadas na análise das atas são aquelas de participação e satisfação. A primeira delas é razoavelmente simples de operacionalizar: uma taxa de participação foi criada tomando-se o número de pessoas presentes em uma reunião conforme registrado em ata, dividindo-se pela população do distrito e multiplicado por 100 mil. (Além de ser uma variável

\footnotetext{
${ }^{19}$ Realizei várias tentativas de criar clusters para formar os grupos em que seriam sorteadas atas em número igual para cada cluster, de forma semelhante ao estrato. $O$ ganho da análise de cluster era permitir usar uma grupo maior de variáveis para criar a amostra e garantir a variabilidade das atas. Foram testadas diversas associações entre variáveis de renda, escolaridade, furto, roubo, homicídios contemporâneos e homicídios históricos para agrupar distritos (e logo, atas) com perfis semelhantes. Em todas as tentativas o resultado final juntava no mesmo cluster Consegs muito diferentes (ex.: Jardins e Capão Redondo) a partir de uma lógica que me escapava. Desse modo optei por não utilizá-la e fazer uma estratificação mais simples com apenas uma variável.
} 
dependente, a taxa de participação também será usada como variável de controle para as análises de satisfação).

Já a variável de satisfação é a mais complexa e delicada da análise e suas limitações precisam ser levadas em conta na leitura dos resultados. A variável satisfação foi criada extraindo-se das atas apenas aquelas informações que foram percebidas como mais confiáveis (ver o início deste capítulo). São informações relativas a problemas concretos e delimitados, tais como necessidade de troca de lâmpadas em frente a determinado endereço, pedido de policiamento localizado, agradecimento por poda de árvores realizadas e assim por diante. Essas falas foram classificadas em agradecimentos, quando o munícipe agradece ou reconhece publicamente um serviço realizado ou um bom atendimento; e reclamação, quando o cidadão solicita um serviço, faz uma denúncia ou reclama do mal atendimento por parte de um servidor público.

- As variáveis independentes

A escolha das variáveis independentes tinha como propósito testar se variáveis de renda, escolaridade e criminalidade tinham impacto nas variáveis dependentes: a) na taxa satisfação dos participantes. Se houver algum traço que seja o oposto da segregação, não haverá diferença nas taxas de satisfação entre os Consegs mais ricos e mais pobres. E b) a taxa de participação nos Consegs. Se Moraes (2011) estiver certa e as manifestações dos moradores forem uma expressão de um desejo de lei e ordem, resultado da insegurança generalizada dos cidadãos nas grandes cidades, as taxas de criminalidade nos diferentes contextos não deverá ter impacto na participação (Capítulo 4, item 4.3).

Os dados de criminalidade são produzidos e divulgados pela Secretaria de Segurança Pública do estado de São Paulo divididos pelos DPs - que é a mesma divisão dos Consegs -, em números absolutos (taxas não estão disponíveis por distrito para todos os anos pesquisados). Para criar as taxas foi calculada a população do distrito. Para a criação das variáveis de roubo, furto e homicídios foram criadas taxas médias para os anos 2010, 2011 e 2012 por 100 mil habitantes (período das atas analisadas) por distrito. A estratégia da taxa média busca diminuir o efeito de flutuações eventuais e pressupões que as ocorrências em geral não devem ter uma variação muito relevante em um período de tempo tão curto.

Foi criada também uma variável que chamei de taxa histórica de homicídios. Escolhi o ano em que a cidade de São Paulo como um todo teve a maior taxa de homicídios da história registrada, o que ocorreu em 1999. A partir daí foi gerada uma média de cinco anos: 1999, os dois anos 
anteriores e os dois anos posteriores (mais uma vez, a média visa a dar menor peso a flutuações e momentos atípicos). Os procedimentos foram os mesmos utilizados para as taxas de roubo, furto e homicídio, com a diferença do período coberto.

Para as variáveis socioeconômicas, foram utilizadas aquelas já coletadas para o desenho da amostragem: porcentagem de ricos (RpDs com renda maior que 20SMs) e porcentagem de pobres no distrito, mais a variável de escolaridade, medida pela porcentagem de analfabetos no distrito ${ }^{20}$.

A variável representante, que mede a presença de ao menos um representante do poder legislativo.

A tabela 2, na próxima página, contém um resumo das variáveis utilizadas nas duas análises das atas (por reunião e por manifestação) e a indicação de onde foram usadas.

${ }^{20}$ O Censo de 2010 não divulgou dados de anos de escolaridade. 


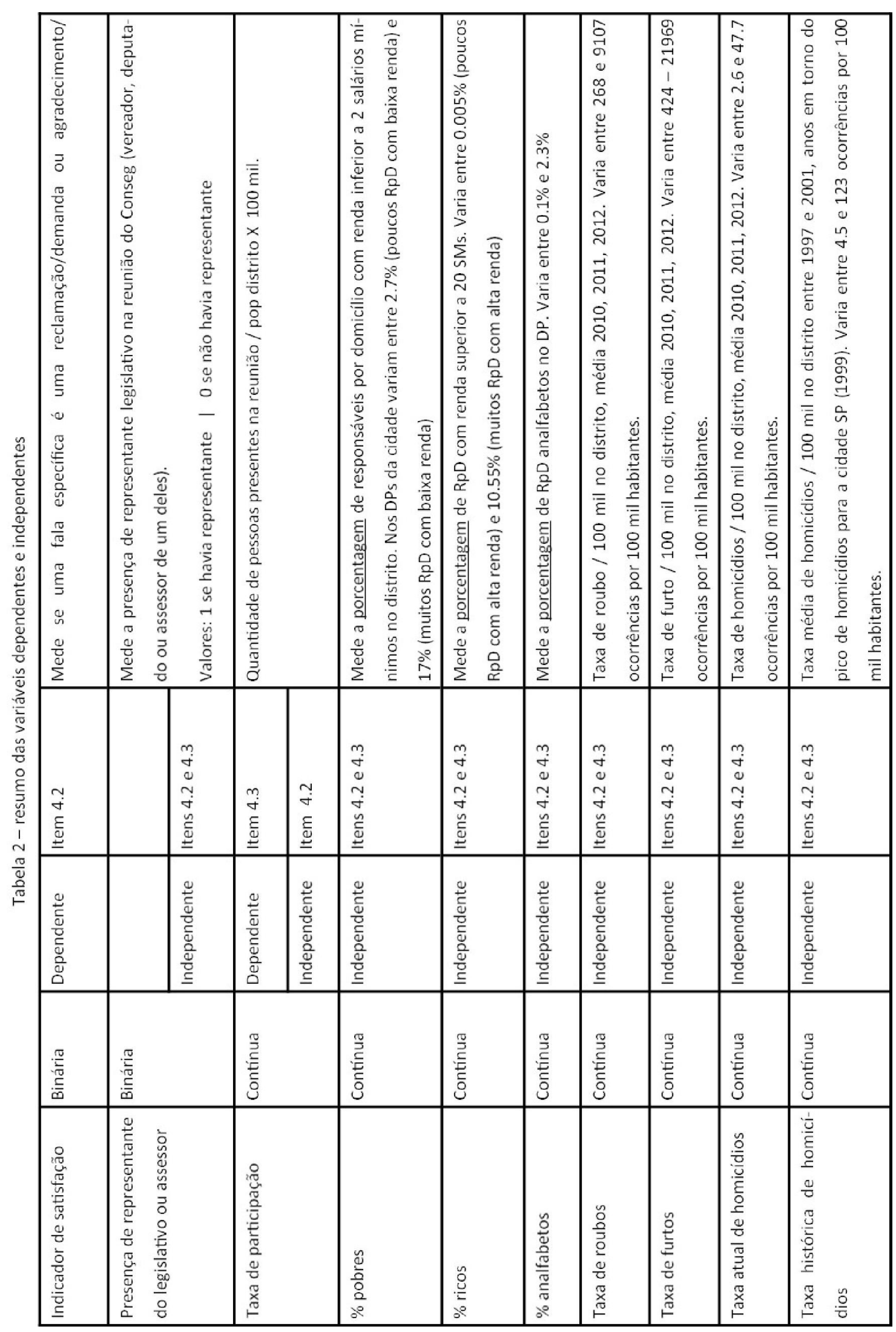




\section{REGRAS DE FUNCIONAMENTO E HISTÓRIA INSTITUCIONAL DOS CONSEGS EM SÃO PAULO}

Os Conselhos Comunitários de Segurança no estado de São Paulo são espaços de encontro entre membros da comunidade e representantes do Estado para a discussão dos assuntos de segurança pública no nível local (distrito policial) ou no nível municipal para cidades menores. A iniciativa para implantação de um Conseg é em geral de moradores de uma determinada localidade que, após cumprir alguns trâmites burocráticos junto à Secretaria de Segurança Pública do estado, tem seu status púbico reconhecido (GURZA LAVALLE, 2011). A partir da institucionalização do Conseg, os membros passam a realizar reuniões mensais, às quais os oficiais das forças policiais civil e militar - responsáveis pela circunscrição têm obrigação de comparecer, embora não haja sanção estabelecida em caso de não comparecimento. Institucionalmente, os Consegs estão ligados à pasta de segurança pública do governo estadual e contam com uma Coordenadoria Estadual responsável por homologar o funcionamento de novas unidades, receber e arquivar atas das reuniões e, mais recentemente, oferecer cursos de capacitação para policiais e comunidade e incentivar a atividade dos Consegs por exemplo através do Prêmio Franco Montoro. No que diz respeito à cidade de São Paulo, há uma grande participação de órgãos da administração municipal nas reuniões e representantes das subprefeituras são figuras bastante demandas pelos participantes e costumam ser centrais ao lado dos representantes das polícias.

Embora não sejam órgãos deliberativos (não produzem decisões vinculantes), não se pode dizer a priori que não influenciam as políticas públicas, ao menos na fase de implementação. Mais adiante, será defendido o argumento de que essa influência existe, mais para as áreas de infraestrutura urbana e menos na área de segurança pública.

Segundo informações publicadas na página da Coordenadoria estadual dos Consegs, atualmente eles estão implantados em 522 municípios paulistas: 84 na Capital, 40 na Região Metropolitana e 660 no Interior e Litoral, totalizando 784 Conselhos $^{21}$.

As reuniões dos Consegs são realizadas mensalmente e conduzidas pelo presidente, um membro da comunidade que faz parte da diretoria que deve ter no mínimo cinco membros e ser eleita a cada dois anos. Embora sejam reuniões abertas a qualquer pessoa da comunidade, para ser considerado um membro efetivo - e poder votar e ser votado nas eleições para a diretoria/presidência -, o participante tem que cumprir certos requisitos e passar por um processo de cadastramento junto à coordenadoria estadual, depois de passar pela aprovação das polícias

${ }^{21}$ http://www.conseg.sp.gov.br/historia.aspx consultada em 06 de julho de 2013. 
militar e civil. A lista de exigências para ser um membro efetivo no Regulamento dos Consegs é um pouco grande e contem itens como não ter antecedentes criminais e residir, trabalhar ou estudar na área de circunscrição daquele Conseg, ser representante de organizações que atuem na área do CONSEG, ou ser formalmente convidado pela Diretoria. Na prática, a maior parte das pessoas que frequentam os Consegs não passaram pelo processo de cadastramento para se tornarem oficialmente membros efetivos. Como as eleições raramente são competitivas e as diretorias tendem a ser escolhidas por aclamação, os membros natos raramente necessitam identificar os membros efetivos para contabilizar votos, embora o façam para homologar as chapas.

Em geral as reuniões são conduzidas pelo presidente que chama para compor a mesa os membros natos, conforme definido pelo Regulamento dos Consegs: o Delegado de Polícia Titular do Distrito Policial onde está localizado o Conseg e o Capitão do Batalhão da área ou um representante dos mesmos. Embora a presença dos membros natos seja, segundo o regulamento, fator central de funcionamento de um Conseg, duas normas foram editadas na esfera municipal que deram destaque a representantes desta outra esfera administrativa, a ponto de esses terem se tornado tão importantes quanto os primeiros nas reuniões. É o caso da lei municipal que estabelece que o Poder Executivo será representado, nas reuniões dos Conselhos Comunitários de Segurança, mediante a participação de um servidor designado pela Administração Regional ou Subprefeitura da região a que pertence o Conselho e um membro da Guarda Civil Metropolitana ${ }^{22}$. A outra visa a assegurar a participação de um representante da Companhia de Engenharia de tráfego ${ }^{23}$. Mas nem sempre a participação das duas esferas administrativas - estadual e municipal - se faz sem tensão. Em uma das reuniões do Conseg Perdizes/Pacaembu ${ }^{24}$, por exemplo, diante da participação articulada do representante da Subprefeitura da Lapa que claramente havia se tornado a figura central da reunião, o presidente fez uma intervenção dramática dizendo que o núcleo dos Consegs eram "esses dois do meu lado" (no caso, o delegado titular e o Capitão da PM) e que os outros (no caso um representante da subprefeitura e um representante da Guarda Civil Metropolitana) eram apenas "apêndices". De qualquer modo, os representantes da subprefeitura sempre se sentam à mesa durante as reuniões junto ao presidente e os membros natos da polícia assim como o representante da Guarda Civil Metropolitana, geralmente o Inspetor. Outros representantes de órgãos públicos que estejam presentes tal como o do Departamento de lluminação Pública - ILUME, Companhia de Engenharia de Tráfego e Secretaria dos Transportes podem, por opção própria, preferir se sentar na plateia, mas são invariavelmente convidados para compor a mesa. As reuniões começam com a fala

\footnotetext{
${ }^{22}$ LEI № 13.299, 16 DE JANEIRO DE 2002.

${ }^{23}$ LEI № 14.901, DE 6 DE FEVEREIRO DE 2009

${ }^{24}$ Reunião observada: Conseg Perdizes/Pacaembu, 18 de junho de 2013, Sede da Sabesp, Rua Cajaíba.
} 
do presidente que pede a saudação do pavilhão nacional ${ }^{25}$ e, às vezes, solicita que se entoe o hino nacional. A sequência básica é o presidente falar, passar a palavra para cada um dos membros da mesa e depois para a plateia para que os participantes se manifestem.

\subsection{O que são os Consegs do ponto de vista oficial}

Galdeano (2009) e Moraes (2011) já chamaram a atenção para a forma como as instituições responsáveis pelos Conselhos Comunitários de Segurança em São Paulo, Rio de Janeiro e Distrito Federal idealizam esses espaços.

Um material de orientação divulgado pela Coordenadoria estadual dos Consegs, órgão da

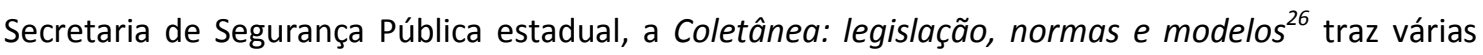
informações, tais como mensagens e diretrizes institucionais, as normas que regem os Consegs, modelos de atas, a letra da canção dos Consegs, instruções para cerimônias de posse etc. Tomando por base a visão expressa nesse material, os Consegs são locais de expressão de um civismo tradicionalista, onde se reverenciam os símbolos da pátria, pregam-se a harmonia e a união entre as classes, Estado e sociedade, os valores da família e nos quais confrontos abertos entre pontos de vista não são uma forma desejável de deliberação.

Juntos agora vamos dar as mãos / Com alegria e muita união / Na busca de soluções / Abrimos os corações / Nossas famílias é que vão ganhar [...] Povo e polícia uma só direção (Canção dos Consegs, SSP-SP, 2011).

Artigo 52 - São deveres comuns aos membros natos, efetivos e visitantes dos CONSEGs: [...]XIII - Estimular a harmonia e o respeito entre os membros da comunidade, a polícia e o governo (Regulamento dos Conselhos Comunitários de Segurança [1999] SSP-SP, 2011).

Do que se pode aprender desse documento, a participação é valorizada, desde que limitada a uma forma muito específica, em termos de subsídios que os munícipes possam dar aos órgãos da lei, ajudando com inputs de informações para que então as autoridades decidam, a partir de critérios que estão fora do âmbito da discussão pública, quais as prioridades na atividade policial local.

\footnotetext{
${ }^{25}$ Aplaudir a bandeira brasileira.

${ }^{26}$ http://www.conseg.sp.gov.br/DownloadDetalhe.aspx?id grupo=4
} 
Consegs solidamente implantados (...) são palpavelmente vantajosos para o administrador policial por representarem importantes instrumentos de avaliação, favorecendo a definição de prioridades para a atuação da polícia (SSP-SP, 2011, pg. 08).

E desde que os participantes não tentem interferir na autonomia técnica dos órgãos policiais:

Artigo 52 - São deveres comuns aos membros natos, efetivos e visitantes dos CONSEGs: [...] XXI - Abster-se o membro efetivo, visitante ou participante de imiscuir-se em assuntos de administração interna ou de exclusiva competência da polícia, tais como elaboração das escalas de serviço, punições disciplinares, movimentação de pessoal, técnicas de planejamento e execução de operações policiais. (Regulamento dos Conselhos Comunitários de Segurança [1999] SSP-SP, 2011).

O meio aceitável para que os membros dos Consegs influenciem o trabalho da polícia são, além do provimento de informações, a motivação e reconhecimento:

Os Consegs, ao par de prosseguirem em sua competente atuação em benefício de suas respectivas comunidades, serão estimulados a exercitarem, com maior intensidade, seu poder de mobilização da opinião pública, enveredando pela ação em áreas estratégicas que têm atuado ainda em ritmo insuficiente; reforçando a autoestima dos policiais, fazendo-os sentir que a comunidade prestigia e respeita o bom profissional da segurança (SSP-SP, 2011, pg. 09).

Nos casos de atuação insuficiente por parte dos membros natos e consequente insatisfação dos demais membros, a questão deve ser tratada internamente, ou pelos superiores hierárquicos ou pela Coordenadoria, conforme as instruções do regulamento [1999]:

SEÇÃO IX - DAS REUNIÕES § 4ำ - Os problemas de segurança persistentes, constantes de atas anteriores e não satisfatoriamente atendidos, bem como ausências constantes de membros natos às reuniões, deverão ser comunicados pelo Presidente, através de ofício circunstanciado ao Coordenador.

SEÇÃO XI - DOS DEVERES DOS ESCALÕES POLICIAIS SUPERIORES VI - Exigir dos membros natos que prestem contas à comunidade, nos termos do artigo 22, XIII. VII - Apurar faltas e aplicar sanções regimentais, nos termos da Seção XII. 
E para tentar garantir a boa imagem da polícia e dos Consegs, é preciso sinalizar que roupa suja se lava em casa:

O Conseg representa ainda, um anteparo para a pronta detecção e correção de problemas nas relações polícia-contribuinte, sanando os erros antes que sejam conduzidos a debate em foros mais amplos, como por exemplo, a imprensa (SSP-SP, pg. 09).

Artigo 52 - São deveres comuns aos membros natos, efetivos e visitantes dos CONSEGs: [...] XVI - Renunciar a criticar o CONSEG, fora de reunião e em público, de modo a prejudicar sua imagem e seu conceito (Regulamento dos Consegs, 1999).

Pelo acima exposto, vê-se que as diretrizes oficiais do Conseg emanam de uma ideologia anti-pluralista, ou pelo menos não pluralista, em que o conflito é percebido como prejudicial à sociedade e em que a deliberação é desejável, desde que suficientemente regulada. Os conflitos precisam ser resolvidos internamente. Além disso, como se pode ver nos trechos seguintes, envolver a política partidária, tal como na abordagem da sociedade civil, não é uma prática vista com bons olhos.

Fazer do Conseg um palco de reivindicações e queixas, sem oferecer alternativas à solução, é outro desvio muito comum que não deve ser estimulado. Inicialmente porque, na maior parte das vezes, o canal hierárquico é tão eficiente quanto o comunitário na previsão de recursos humanos e materiais, cuja distribuição, numa administração séria, segue critérios técnicos e não político (SSP-SP, 2011, pg. 6).

...outro problema muito comum, a atrapalhar o bom andamento dos Consegs é o surgimento de lideranças inadequadas ao trabalho comunitário: pessoas que buscam auferir vantagens pessoais, financeiras ou eleitorais dos Consegs, prejudicando sensivelmente a pureza dos objetivos que norteiam os Conselhos, sua força e legitimidade (SSP-SP, 2011, pg. 5, grifo meu).

Ainda que pese toda a lógica hierárquica e um conjunto de regras extenso visando a disciplinar comportamentos, não se pode dizer que o regulamento dos Consegs seja a imagens e semelhança das descrições da literatura sobre uma lógica militar ainda com resquícios da ditadura em que o inimigo interno deveria ser eliminado. Diz o artigo 52 que entre os deveres de todos os 
membros do Conseg está o de "Desestimular a apologia à violência, o descumprimento das leis e a violação dos direitos fundamentais da pessoa humana como solução para os problemas de segurança da comunidade".

Quanto à questão política, líderes comunitários legítimos são aqueles que não se envolvem com a política eleitoral e partidária. Já as polícias são, segundo essa visão, ontologicamente apolíticas, são consideradas sobretudo técnicas e neutras e o caráter corporativo da instituição é absolutamente ignorado:

É certo que, se as autoridades policiais não se mobilizam, inicialmente, para localizar líderes comunitários legítimos e para convidá-los a organizar o Conseg de sua área de atuação, aventureiros e interesseiros poderão se oferecer para assumir essa liderança. [...] Deixá-los assumir tais espaços, que resistirão em abandonar, com prejuízo e desgaste para a administração pública e para a comunidade, via de regra, pode ser em grande parte atribuído ao desinteresse das autoridades policiais da área respectiva." (SSPSP, 2011, pg. 5 e 6).

Ainda nas diretrizes para os Consegs há uma "relação ideal de públicos para os CONSEGs" em que estão elencados 79 tipos de "públicos", entre eles uma infinidade de organizações coletivas, mas nenhuma vez aparece a palavra sindicato. Talvez os sindicatos sejam excessivamente próximos da política partidária, proximidade que os ideólogos dos Consegs acreditam que podem evitar.

O artigo $2 \%$ do regulamento dita que os CONSEGs serão representados coletivamente, e em caráter exclusivo, pelo Coordenador, que é escolhido pelo governador, que é por sua vez, eleito. Ou seja a escolha do governador tem duas consequências: bloqueia a ascensão de adversários políticos e evita correr o risco de quebra de hierarquia, tão cara à polícia militar. Ou seja, ela é políticopartidária, ainda que seja possível imaginar que a intenção original dos formuladores fosse a manutenção da ordem e da hierarquia, independentemente do partido no poder.

Mesmo com o traço político da escolha do coordenador, a atuação político-corporativa das polícias (ponto que será demonstrado na próxima sessão) e a eleição de ex-policiais para cargos nos legislativos municipal, estadual e federal, a versão oficial insiste em rechaçar esse conteúdo no mundo dos Consegs.

Não se pretende argumentar aqui que as diretrizes emanadas dos regulamentos sejam seguidas à risca, mas elas orientam sim a atuação dos participante, claramente, naquilo que diz 
respeito à autoridade da polícia. Como será defendido no capítulo 4, item 4.4, existe uma espécie de deferência em relação às agências policiais e seus representantes e defende-se aqui que essa deferência emana, ao menos em parte, do regulamento.

\subsection{A formação dos Consegs}

No Brasil, os Consegs apareceram pela primeira vez no estado de São Paulo ${ }^{27}$, durante o primeiro governo eleito democraticamente, já no fim do último período ditatorial, que se estendeu de 1964 a 1985. Para um estudioso da participação, seria natural supor que a criação dos Consegs segue uma matriz conselhista, afinal, o governador recém-eleito, Franco Montoro, tinha uma orientação notoriamente comunitarista, pró-descentralização e pró-participação. Na descrição de Sento-Sé (2005) o ideal de descentralização como parte constitutiva do processo de democratização, teria sido, ao menos em parte, a inspiração para os Conselhos Comunitários do estado do Rio de Janeiro: "uma ação para conceder maior responsabilidade aos poderes locais no que toca a implementação e gestão de políticas públicas", conforme previsto na constituição 1988 e que tem sido levado a cabo, em diversas áreas de política, já desde início da década de 80 . Aparentemente houve uma disputa entre a matriz democrática e conselhista dos aliados de Montoro e outra de inspiração da polícia comunitária/teoria das janelas quebradas.

Talvez essa seja uma das maiores fontes de perplexidade e insatisfação dos ativistas de direitos humanos, defensores dos direitos civis e de pesquisadores do crime e violência nas ciências sociais a respeito dos Consegs. A inspiração participativa da Constituição de 1988 tem uma boa parte de sua base nos movimentos sociais e está calcada em um ideal de emancipação e inclusão política das camadas desfavorecidas e diminuição das desigualdades sociais. Mesmo que a participação seja muitas vezes induzida pelo Estado, ainda assim ela emana da ideologia participacionista que inclui descentralização e participação da sociedade para além do momento das eleições. Já a inspiração da polícia comunitária, que em parte inspirou os Consegs e que começou a ser formulada nos anos 60 é mais diversificada e tem vertentes muito inclinadas ao autoritarismo, com receitas de restrição de circulação e restrição aos direitos civis (leis do tipo three strikes you're out, mencionada primeiro capítulo) que geralmente recaem sobre os mais pobres e socialmente estigmatizados (MESQUITA, 2011).

No que diz respeito à segurança pública, a transição pactuada justamente com os governantes da ditadura militar não permitiu inovações nessa área de política. Durante a ditadura,

\footnotetext{
27 Há notícia da criação ainda nos anos 80 de um conselho comunitário no estado do Paraná, de caráter espontâneo e voluntário, sem reconhecimento governamental. Não serão considerados aqui.
} 
todo o aparato de segurança pública havia sido mobilizado para, além de suas funções regulares, combater dissidentes políticos ${ }^{28}$, vistos como um inimigo de guerra que, em alguns casos, deveriam ser eliminados (PINHEIRO, 2001). As polícias ficaram subordinadas ao exército e a criação da PM deu um perfil militarizado para o policiamento ostensivo. As negociações para a transição democrática não permitiram que se mexesse na segurança pública de modo que a Constituição de 1988 não trouxe mudanças na estrutura nesta área. As alterações incrementais que vêm ocorrendo, embora relevantes, ainda não se acumularam suficientemente a ponto de configurarem uma mudança de trajetória.

Mas antes mesmo da passagem do mando militar para o civil na esfera federal, Franco Montoro se candidatou para as eleições de 1982 tendo como uma de suas principais bandeiras a completa mudança das polícias em São Paulo (CALDEIRA, 2000; MINGARDI, 1999). As próximas páginas buscam remontar na trajetória de Franco Montoro os dois elementos mais importantes para a existência dos Consegs: as ideias sobre participação e a questão da segurança pública.

Há profusão de documentos imediatamente anteriores à eleição de Franco Montoro que reproduzem seus discursos como Deputado Federal e Senador, desde antes do golpe militar, em defesa das ideias políticas de descentralização e participação dos cidadãos na administração pública. As ideias que hoje chamaríamos de participacionistas de Franco Montoro eram coerentes com sua adesão à Democracia Cristã, um movimento que acontecia em vários países do ocidente depois da segunda guerra que se apresentava como a terceira via em relação ao "liberalismo burguês individualista" e a "opressão do comunismo" e se materializou em partidos políticos, sobretudo na Europa e na América Latina (COELHO, 2003). Em 1959 Montoro se elegera deputado federal pelo Partido Democrata Cristão e, em 20 de abril de 1961 lê, na Câmara dos Deputados, a declaração de princípios do PDC, elaborada na Convenção Nacional do Partido. A declaração era estruturada em torno de sete princípios, entre eles, um pluralismo bastante específico:

Pluralismo: [A Democracia Cristã] Afirma que essas reformas de estrutura e promoção do bem comum se hão de fazer mediante a necessária intervenção do Estado, mas no sentido de uma descentralização, ou pluralismo comunitário, que respeite e fortaleça os grupos sociais intermediários como a família, o município, o sindicato, a empresa, a escola, a cooperativa e outros, que não poderão ser absorvidos ou eliminados pelo poder centralizador do Estado (CÂMARA DOS DEPUTADOS, 2009, pg. 104).

\footnotetext{
${ }^{28}$ Que as forças de segurança pública perseguissem dissidentes políticos não era novidade na história do Brasil. A diferença foi o caráter sistemático, planejado e estruturado dessas atividades durante a ditadura militar.
} 
A fórmula geral comunitária de fortalecimento das "instituições intermediárias" era aplicada às diferentes áreas da política em propostas específicas, pregadas por ele nos discursos na Câmara Federal entre 59 e 67 . Na política habitacional ele defendia as cooperativas de crédito e os mutirões $^{29}$; no mundo do trabalho, a participação dos empregados nos lucros e na direção das empresas públicas e também das privadas ${ }^{30}$; no campo, a partir da reforma agrária, "a organização dos trabalhadores rurais em comunidades democráticas de produção" ${ }^{\prime 31}$. Na reforma eleitoral ele pretendia que as convenções partidárias tivessem certas regras e fossem fiscalizadas pela Justiça Eleitoral de modo que os partidos não fossem controlados pelos caciques, mas sim pela vontade da maioria de seus filiados ${ }^{32}$.

Se por um lado essa participação poderia guardar semelhanças com o modelo corporativista do Estado Novo, por outro, havia pelo menos dois componentes dessa ideologia que apontavam na direção oposta: o papel dos sindicatos e a descentralização da administração pública. Diferentemente de parte do modelo participacionista atual, o papel dos sindicatos era absolutamente centra $\left.\right|^{33}$ para contrabalançar o poder do capital e do Estado. Segundo ele, também inspirado na Democracia Cristã, a descentralização estatal, era complementar à participação popular:

Confiar aos governos locais uma soma maior de atribuições ligadas à realização do bem-estar econômico-social de seus governados (educação primária e profissional elementar; assistência médico-hospitalar; fomento da produção; segurança pública; transportes urbanos e rurais; distribuição de energia elétrica; abastecimento de água; saneamento urbano etc.) conferindo-se-lhes, paralelamente, um maior quinhão na partilha das rendas públicas (Discurso sobre os princípios do Partido Democrata Cristão proferido em 20/4/1961. CÂMARA DOS DEPUTADOS, 2009, pg. 107).

Muitos anos depois daquele discurso, ele afirmaria ter seguido essa diretriz como governador de São Paulo, nas palavras do seu discurso de transmissão do cargo em 1987:

\footnotetext{
${ }^{29}$ Discurso de Franco Monto em junho de 1964, comentando projeto de reforma habitacional enviado pelo governo ao Congresso. Câmara dos Deputados, 2009, pg. 144 a 147.

${ }^{30}$ Discurso de 1961, pg. 107. Discurso de 1963, pg. 120,122. Discurso de 1966, crítica ao projeto constitucional de 1967. Pg. 179. Discurso de 1967, Pg. 182. Câmara dos Deputados, 2009.

${ }^{31}$ Discurso de 1961, pg. 106. Discurso de 1967, pg. 183. Câmara dos Deputados, 2009.

32 Discurso de maio de 1964. Câmara dos deputados, 2009, pg. 130, 133.

33 Discurso de 1961, pg 107. Discurso de 1963, pg. 123. Discurso de 1967, pg. 182. Câmara dos Deputados, 2009.
} 
Em vez de centralizar recursos e poder, meu governo [...] procurou desburocratizar a máquina do Estado, entregando, sempre que possível, poderes e recursos aos municípios e órgãos locais. Foi assim na municipalização das construções escolares e merenda escolar, com o estímulo à produção local de alimentos. Foi assim na multiplicação e descentralização dos centros de saúde, estradas vicinais, nos Fundos Municipais de Solidariedade, na criação das legiões de governo e nos mutirões da casa própria (CÂMARA DOS DEPUTADOS, 2009, pg. 309).

Se no Chile de 1973 o Partido Democrata Cristão ajudaria a derrubar Salvador Allende, antes disso Montoro percebia a Democracia Cristã como um movimento de resistência, afirmando que "Na Europa, os democratas cristãos [...] numa de suas manifestações mais ativas, na Espanha de Franco e em Portugal de Salazar. Representam, os movimentos democratas cristãos, uma esperança, aliados a outros de derrubada dessas duas ditaduras" (CÂMARA FEDERAL, 2009, pg. 96) ${ }^{34}$. Nesse raciocínio, se as ditaduras eram centralizadas, logo, a democracia deveria ser descentralizada.

Se Franco Montoro já defendia uma ideia de participação direta análoga e mais ampla que o corporativismo em que os cidadãos que não fazem parte do Estado participam de algum grau da administração pública através da ação direta em conselhos, comissões, cooperativas etc., essa ideia vai ganhar força no momento da ditadura quando mesmo a participação minimalista na forma representativa - através do voto universal e das liberdades políticas e de expressão - será severamente limitada. Se Montoro já defendia a democracia participativa desde antes do golpe de 1964, depois dele, Montoro passa a ter que defender também a democracia representativa. É a partir desse momento que a defesa dos dois tipos de participação vai se misturar e participação vai se referir ora ao voto direto, ora a participação participacionista. O ideal da participação em Montoro, de resto como em diversas outras vertentes, nasce em grande medida ligado à questão mais premente do século XX: a distribuição mais igualitária dos resultados do desenvolvimento econômico acelerado do pós-guerra. Era esse o centro da disputa capitalismo-comunismo. É na área de política social que ele vai ter seu foco e maior importância. Não é de admirar que a política de segurança pública não tenha nenhum destaque nessa ideologia.

A expressão exata "democracia participativa” aparece no livro "Da Democracia que temos para a Democracia que queremos", que reúne discursos proferidos no Senado entre 1971 e 1974 ,

\footnotetext{
${ }^{34}$ As trajetórias dos partidos da Democracia Cristã adquirem rumos diversos em função do perfil no país ou mesmo de seus membros. No Chile o partido esteve na oposição ao governo de Unidade Popular contribuindo para o golpe contra Salvador Allende em 1973. Em situação análoga, quando a posse de João Goulart é ameaçada no Brasil após a renúnica do presidente Jânio Quadros, Montoro defende a legalidade, ajuda a costurar a solução parlamentarista e em seguida se torna Ministro do Trabalho no novo gabinete.
} 
além de alguns outros textos. Em um dos discursos, intitulado no livro "Democracia participativa e seus fundamentos" (proferido em setembro de 1972), ele dá nome a uma ideia que já vinha delineando há muito tempo:

Camadas cada vez mais amplas da população tomam consciência do caráter meramente formal e aparente de certas fórmulas democráticas, em que a participação do povo é mais simbólica que real. (...) É preciso descobrir novos caminhos dentro da via democrática. E entre os caminhos possíveis (...) situase a democracia participativa, comunitária ou federalista. Esta pode ser caracterizada como modelo de organização democrática, fundado não apenas na "representação" popular, mas também, na "participação" organizada e ativa de grupos sociais nos assuntos de seu interesse (MONTORO, 1974, pg.42. Grifo meu).

Ele coloca a organização da comunidade como uma espécie de atitude cívica e exalta os órgãos administrativos a acolher as decisões dessas organizações. Há algumas ideias de instituições participativas, especialmente no sentido de os cidadãos tomarem parte em alguma comissões de fiscalização de assuntos do governo, mas a predominância é a exaltação da organização associativa, da mobilização de baixo pra cima. Ainda não estava disponível o modelo "conselhista" amplamente institucionalizado como conhecemos hoje, mas ele recomenda que a legislação deve "disciplinar esta atividade", ou seja, que a participação deveria ser institucionalizada. Olhando do ponto de vista do século XXI, tendo disponíveis as lentes da literatura da sociedade civil é curioso que para Franco Montoro os partidos políticos e os sindicatos fossem estruturas fundamentais da vida participativa. Os partidos para ele são os meios de participação no processo político que "é a participação fundamental, que não pode ser substituída ou sonegada por quaisquer outras espécies de participação social ou econômica" (MONTORO, 1974, pg. 53). Os partidos políticos eram importantes para Montoro, antes e depois do golpe, não estavam fora de suas ideias de democracia participativa, ao contrário.

Os setores da política aos quais ele recomenda a participação no período $71-74$ vão se ampliando, tornados palpáveis com exemplos de instrumentos da democracia participativa como a participação de jovens estudantes nos órgãos colegiados das escolas, juntas de vizinhos, como no Chile e com associação de consumidores e sindicados no planejamento do desenvolvimento social e econômico. Não parecia haver nenhum setor de política em que não se pudesse aplicar a fórmula da participação. 
No ano da eleição para governador, 1982, dois livros seus foram publicados simultaneamente: "Alternativa comunitária: um caminho para o Brasil", pela editora Martins Fontes e “Leis e projetos de inspiração comunitária” pela gráfica do Senado.

Na introdução de "A alternativa comunitária, um caminho para o Brasil", Montoro fala em "despertar da sociedade civil" e começa a articular a ideia de instituições participativas, falando em "processos participativos" na elaboração das políticas, inclusive para o setor energético. Aparece a recomendação à participação dos trabalhadores "em instituições e conselhos de interesse social e, particularmente, naqueles mais vinculados ao trabalhador como o INPS, o PIS/PASEP...". A segunda parte do livro é dedicada a descrever as propostas pretéritas do congressista como deputado e senador. Inclui todo tipo de proposta conforme pesquisadas pelos assessores de Montoro no Senado e no livro são todas consideradas "de inspiração comunitária". Na terceira parte é feita uma relação de exemplos do que seriam "experiências de participação da população em atividades comunitárias ou amostras de democracia participativa". Não há nenhum exemplo ou menção à área de segurança.

Em "Leis e projetos de inspiração comunitária", são reproduzidos os projetos de lei propostos por Montoro na área de "fortalecimento dos municípios e das regiões", "participação de representantes das comunidades em instituições públicas" (participação dos representantes dos empregados e empresários na administração da previdência social, participação de um representante da Confederação Nacional dos Trabalhadores na Agricultura - CONTAG - na Comissão Nacional do Açúcar e do Álcool, comissões de empresários e trabalhadores na fiscalização da apuração do Índice Nacional de Preços ao Consumidor, direito de as entidades de classe se pronunciarem sobre proposições em andamento no Senado, ampliação da participação de entidades de classe no Conselho de Defesa dos Direitos da Pessoa Humana, criação da Comissão Nacional do Custo de Vida no Ministério do Trabalho com composição mista de órgãos do mundo do trabalho e governo), direitos trabalhistas e previdenciário “participação e integração dos empregados na vida da empresa (vários apenas trabalhistas, outros de inspiração mais participativa tal como: assegurar a participação dos empregados na direção de empresas públicas e sociedades de economia mista, aperfeiçoamento das eleições para as Comissões Internas de Prevenção de Acidentes nas empresas), fortalecimento dos sindicatos e "defesa das cooperativas e outras formas de participação".

O projeto participativo que Montoro foi desenvolvendo ao longo da carreira política com deputado e senador a) não tinha como pressuposto a separação entre circuito da política tradicional (partidos políticos) e os atores societários e; b) embora pudesse ser aplicado a inúmeras áreas de política, não há sinais de que tenha sido formulado para a área de segurança pública. 
Já a questão da polícia, essa se tornou central na sua campanha para governador em 1982. Nessa área, um grupo de delegados elaborou um projeto para a reforma da polícia. Nas descrições da época aparecem, além das denúncias de torturas e assassinatos contra presos políticos por parte do regime militar, uma polícia violenta contra presos comuns e amplamente corrupta. A mudança na polícia para que se adequasse para o novo período de democracia que se anunciava na vida política do país, era parte fundamental na campanha eleitoral do PMDB, partido que então abrigava uma boa parte dos opositores do regime militar. A proposta para a área de segurança seria montada por um grupo de delegados que, pensando na reforma da polícia já desde 1980, foi chamado por Montoro. A pedido da Associação dos Delegados de Polícia de São Paulo, Maurício Henrique Guimarães Pereira, Roberto Maurício Genofre e Guilherme Santana haviam elaborado um diagnóstico com recomendações para a área. Talvez por esse viés, a proposta de Montoro para a área estava muito focada na polícia civil. Os problemas estavam concentrados na baixa eficiência policial, violência e corrupção. Eles apontavam para o problema das prisões para averiguação em que o criminoso ficava detido sem nenhum registro, dando margem à corrupção e arbítrio; no excesso de burocracia durante o inquérito policial que dificultava o trabalho; na falta de preparo dos policiais que fazia com que a violência fosse o principal instrumento na elucidação de crimes e na existência de duas polícias - militar e civil. Quando chamados para integrar o grupo que planejava a campanha, esses delegados acabaram dando o tom da proposta de Montoro para a segurança pública já que os oficiais militares não tiveram uma adesão no topo da hierarquia e os tenentes coronéis que aderiram, pouco compareciam, possivelmente em função de pressões da corporação (CALDEIRA, 2000; MINGARDI, 1992). Para além de soluções para os problemas diagnosticados em 1980, o documento redigido por Pereira, Genofre e Santana tinha duas menções a algum tipo de gestão mais democrática da polícia: a ideia de escolha do o Conselho da Polícia Civil por voto de todos os delegados e a participação de usuários nas comissões de licitação. São duas propostas coerentes com o programa político de Montoro que desde a década de 50 falava de participação popular e comunitária na política pública. Em comparação com a proposta de Montoro para as outras áreas da política, essas ideias de participação eram um pouco modestas, mas eram consistentes com os vários modelos de participação comunitária defendidos por ele. A ideia de Conselhos Comunitários de Segurança não aparecia nestes documentos. Além da proposta dos delegados para moralizar a polícia, o respeito aos direitos humanos era central para Montoro.

Vencida a eleição, a reforma da polícia deveria ser implantada. Aquele era um momento de transição de regime no país, um momento fundador com possibilidades reais de inovação. Os participantes da elaboração do programa de governo de fato tiveram espaço depois das eleições, 
como Mauricio Genofre, Guilherme Santana e José Oswaldo Vieira. Maurício Henrique Guimarães Pereira foi escolhido delegado-geral e o Secretário de Segurança pública era Manuel Pedro Pimentel.

A conquista do poder eleitoral, porém, não implicou necessariamente a imposição do controle sobre os órgãos da violência do Estado. Algumas reformas foram de fato realizadas, mas os primeiros reformadores caíram em menos de um ano após enfrentar grande resistência por parte de vários grupos dentro das corporações das polícias civil e militar. Atribuir à reforma policial destacando negativamente o papel dos direitos humanos - a culpa por todos os problemas da criminalidade em São Paulo foi o caminho escolhido pelos refratários nas corporações e políticoscomunicadores sociais aderiram ao mote "direito de bandidos" para obter dividendos políticos diante da crise da segurança pública e do aumento da criminalidade (CALDEIRA, 2000).

O primeiro secretário de segurança, Pedro Pimentel, ocupou a pasta por seis meses, o famoso jurista Miguel Reale Junior, por menos de cinco meses. Michel Temer foi o terceiro a assumir a secretaria em janeiro de 1984 e tinha como missão pacificar os conflitos dentro da polícia. Temer teve algum êxito em sua tarefa e só deixou o cargo para poder disputar uma vaga de deputado federal na eleição de $1986^{35}$. Foi justamente na gestão de Temer que os Consegs foram criados. Galdeano (2009) afirma, a partir do depoimento do Secretário de Descentralização e Participação da gestão Montoro, José Gregory, que teria havido um primeiro estudo para a criação dos Consegs formulado pela assessoria de direitos humanos do governador Montoro. Notícia da Folha de São Paulo, de 07 de julho de $1985^{36}$ afirma que o governador teria assinado decreto autorizando a instalação dos primeiro 13 "Conselhos Comunitários de Segurança e Defesa do Homem" no Estado. O nome do Conselho que aparece na notícia de fato tem um componente de direitos humanos e talvez houvesse uma ideia para os Consegs um pouco diferente daquilo que viriam a se tornar. 0 grupo que estaria formulando os Consegs teria sido afastado da tarefa após a crise:

Com a criação do cargo de coordenador dos assuntos do Conseg, a implementação dos conselhos fica a cargo da Secretaria de Segurança Pública e sob responsabilidade dos delegados locais - muitos dos quais janistas e contrários às mudanças propostas por Montoro. Os delegados passam a ter como tarefa mobilizar a sociedade para participação nos conselhos. Nessa segunda fase, os Consegs deixam de estar sob responsabilidade do grupo de direitos humanos, o que compromete o perfil ideológico de policiais e representantes da sociedade civil desejado desde o início. (GALDEANO, 2009, p. 35)

\footnotetext{
${ }^{35}$ Na propaganda eleitoral impressa, Michel Temer anunciava como um de seus feitos a criação dos Consegs.

${ }^{36}$ http://acervo.folha.com.br/fsp/1985/07/07/2/ Donwload em junho de 2011.
} 
Aparentemente, o momento da criação dos Consegs explica em grande parte seu desenho institucional. Os atores envolvidos criaram o tipo de desenho que Ihes garantia a precedência nas reuniões. Se os atores do movimento de direitos humanos ou outros atores civis, não ligados diretamente às instituições policiais tivessem mantido sua posição vantajosa na formulação dessa instituição é possível que o resultado tivesse sido diferente.

\subsection{A normatização: disputa na ampliação das atribuições dos Consegs}

A existência e funcionamento dos Consegs estão baseados principalmente em atos do poder executivo estadual: o decreto de criação no $23.455 / 1985$, a resolução que os regulamentou (SSP37/1985), o decreto que criou o cargo de coordenador (25.366/86). Uma resolução posterior redefiniu o regulamento (SSP-47/1999) e o decreto, 25.366/86 que criou na estrutura da SSP-SP o cargo de coordenador, viria a ser substituído por lei específica em 2005.

Em 2002, pretendendo dar mais "estabilidade institucional" aos Consegs, o então governador Geraldo Alckmin, enviou à Assembleia Legislativa o projeto de lei n.․ 579/2002, acompanhado da seguinte mensagem:

A existência e o êxito dos Conselhos Comunitários de Segurança - CONSEGs constituem um triunfo do povo e do Governo do Estado de São Paulo. Por essa razão, e para que tais Conselhos ganhem maior estabilidade institucional, compatível com o "status" que têm hoje na sociedade paulista, torna-se necessário fixar sua origem em lei. (A n.o 96/2002 Governador Geraldo Alckmin).

O novo projeto pretendia substituir tanto o decreto de criação do Conseg quanto o decreto de criação do cargo de coordenador "desempenhada por integrante da Administração direta ou indireta do Estado, designado pelo Governador do Estado". O projeto rapidamente recebeu duas propostas de substitutivos. Uma delas, da base aliada, apresentada, entre outros, pelo deputado Campos Machado (PTB), aumentava o número de cargos de um para três na Coordenadoria com o acréscimo de dois servidores técnicos. O outro substitutivo, de autoria da oposição, apresentado pela deputada Mariângela Duarte e mais quatro deputados, todos do Partido dos Trabalhadores (PT), pretendia aumentar as atribuições do Conseg como uma instituição de controle da polícia: 
Artigo 10 - Ficam criados, junto à Secretaria de Segurança Pública, os Conselhos Comunitários de Segurança - CONSEG's, com o objetivo de participar da elaboração da Política Pública de Segurança do Estado, acompanhar sua implementação e avaliar a consecução das metas sobre a contenção da violência e redução da criminalidade, no território de atuação e responsabilidade do Delegado de Polícia Titular do Distrito Policial ou da Delegacia de Polícia do Município, bem como do Comandante da Unidade Policial Militar da área do Distrito Policial ou do território do Município ${ }^{37}$ (grifo meu).

Deixar atores societários participar da elaboração, acompanhar a implementação e avaliar a consecução de metas eram objetivos completamente descompassados em relação às ideias que vinham prevalecendo - e continuam hegemônicas -, na gestão da segurança pública do estado de São Paulo. Diante da apresentação dos dois substitutivos, o projeto original foi retirado pelo próprio poder executivo em de junho de 2003, com a única justificativa de "reexame da matéria". ${ }^{38} \mathrm{Em} \mathrm{2004}$, o deputado Romeu Tuma fez uma indicação ao Governador para que reenviasse o projeto de lei que tratava da criação dos Consegs ${ }^{39}$. O deputado foi atendido e, em vez de apresentar um projeto de estabilidade institucional dos Consegs, o mesmo governador Geraldo Alckmin apresentou, no começo de 2005 um projeto de estabilidade institucional para a Coordenadoria. A Lei Complementar no 974, de 21 de setembro de 2005, criou na estrutura básica da Segurança Pública, a Coordenadoria Estadual dos Conselhos Comunitários de Segurança com oito cargos técnicos mais o cargo de coordenador. Nessa nova lei, os Consegs propriamente ditos, entram de forma secundária mantendo a validade dos instrumentos legais - decretos executivos -, que os haviam criado. Segundo o artigo $2 \circ$ :

Os Conselhos Comunitários de Segurança - CONSEGs, de que tratam o Decreto no 23.455 , de 10 de maio de 1985, e o Decreto no 25.366, de 11 de junho de 1986, são entidades de apoio aos órgãos policiais no campo das relações comunitárias, vinculando -se, por adesão, às diretrizes estabelecidas pela Secretaria da Segurança Pública, por intermédio da Coordenadoria Estadual dos Conselhos Comunitários de Segurança, criada pelo artigo 1 을 desta lei complementar.

Como notaram Galdeano (2009) e Moraes (2011), existe um apetite regulatório, uma percepção por parte das instituições públicas de que os Consegs devem ser órgãos de auxílio,

37 http://www.al.sp.gov.br/propositura/?id=158608, acesso em novembro de 2013.

38 http://www.al.sp.gov.br/propositura/?id=158608, acesso em novembro de 2013.

${ }^{39}$ Indicação 396/2004, Diário Oficial do Estado de São Paulo, 25 de março de 2004, pg. 114. 
regulados por eles, trabalhando como os olhos da polícia na comunidade - seja indicando prioridades, realizando denúncias ou até mesmo como defensores da imagem da polícia. Muito do que se lê nos regulamentos transparece na atitude dos membros da diretoria dos Consegs como se verá na discussão do capítulo 4, item 4.4. Mas, na descrição de Moraes (2011) para os conselhos do Rio de Janeiro e Brasília, os indivíduos que fazem os Consegs eram capazes de reinventá-los, confrontando as autoridades, inclusive policiais, sempre que parecesse adequado. No caso de São Paulo, os constrangimentos a uma atuação mais autônoma dos participantes não são banais - além o apetite regulador das normas, deve-se levar em conta a precariedade de sua institucionalização. Isso não quer dizer que não tenham ocorrido tentativas de mudança e ampliação das atribuições dos atores societários pertencentes aos Consegs -seja por parte deles mesmos ou por parte de atores do circuito formal da política, inclusive de orientações partidárias variadas.

Em 2009, o deputado Olímpio Gomes, ex-oficial da polícia militar e então membro do Partido Verde, entrou com o projeto de lei complementar № 16 objetivando "contribuir para democratização do processo de escolha e nomeação do Coordenador dos CONSEGs" propondo que essa fosse realizada mediante a escolha de um nome a partir de uma lista tríplice, elaborada mediante consenso dos membros dos CONSEGs sediados na Capital e no Interior do Estado de São. Foi arquivado em 2011.

Em 2011, o deputado petista Edinho Silva propôs o projeto de lei 413, dispondo sobre a criação do Conselho Estadual e Conselhos Regionais de Segurança Pública e Cidadania. O Conselho Estadual teria entre suas competências, a de "colaborar com a elaboração do Plano Estadual de Segurança Pública" e "monitorar e fiscalizar a execução de políticas públicas no âmbito da Segurança Pública, Assuntos Penitenciários e de medidas socioeducativas no Estado de São Paulo". Embora fosse composto largamente por membros da administração estadual, o Conselho Estadual de Segurança Pública, segundo tal projeto, deveria ter entre seus quadros cinco conselheiros regionais, escolhidos entre os presidentes dos Consegs de cinco diferentes regiões do estado. $O$ projeto recebeu veto total do governador, com alegação de inconstitucionalidade ${ }^{40}$, mas voltou a câmara com pareceres favoráveis ao projeto e contrários ao veto em três comissões. Em março de 2013 o projeto ainda tramitava.

Já o projeto de lei 16, de 2004, da deputada Maria Lúcia Amary, do próprio partido do governador (PSDB) pretendia tornar lei que se notificassem os Conselhos Comunitários de Segurança

40 “...acerca do tema atinente à criação de órgão público, o Supremo Tribunal Federal declarou a inconstitucionalidade da Lei no 9.170, de 18 de maio de 1995, do Estado de São Paulo, que, provinda de iniciativa do Parlamento, tinha por escopo criar órgão colegiado integrante da Administração Pública." Mensagem A-no 036/2013, do governador do estado http://www.al.sp.gov.br/propositura/?id=1008985. 
os casos de óbitos e de lesões corporais originadas de violência interpessoal. O projeto parou de tramitar em 2005.

Outro projeto, (№ 872/2005) pretendia autorizar os Conselhos Comunitários de Segurança a realizar o credenciamento de vigilantes de rua. De autoria do ex-coronel da PM Ubiratan Guimarães $^{41}$ (PTB), teve parecer favorável da Comissão de Constituição e Justiça e da Comissão de Segurança Pública, mas parou de tramitar em 2006.

Não se pode dizer que os Consegs não mudam nunca. Segundo Galdeano (2009), o atual regulamento dos Consegs, publicado em 1999, foi escrito a partir da contribuição de um Grupo de Trabalho constituído por três membros da Polícia Civil, três membros da Polícia Militar, dois líderes comunitários, a secretária da Coordenadoria de Análise e Planejamento (CAP) e um membro do Núcleo de Estudos da Violência da Universidade de São Paulo, organização com conhecida atuação na pesquisa e defesa dos Direitos Humanos. Com grande dificuldade em conter o apetite regulatório dos policiais, os civis teriam pelo menos conseguido incluir um artigo que visava a controlar a preponderância das polícias nas atividades dos Consegs.

Artigo 43 - As reuniões do CONSEG terão cunho público e serão abertas, devendo realizar-se em local de fácil acesso à comunidade, preferencialmente em imóveis de uso comunitário e que não sediem órgão policial (grifo meu).

$\mathrm{O}$ artigo 43 certamente tem sido respeitado pois, diferentemente do que acontecia antes da publicação do regulamento atual (1999), não tive informação de nenhuma reunião realizada em delegacia de polícia civil ou batalhão militar. Esse caso traz duas evidências importantes: a) a de que existe uma importante influência do regulamento nas práticas dos Consegs e b) existe disputa a respeito das atribuições dos Consegs e um desejo por parte dos atores societários de ampliar essas atribuições. Em uma das reuniões observadas no Conseg Perdizes/Pacaembu ${ }^{42}$, o presidente manifestou esse desejo. No mês de julho de 2013, o Secretário de Segurança Pública havia anunciado a criação da Câmara Técnica de Análise, Pesquisa e Estatísticas em Segurança Pública e Atividade Policial do qual fariam parte o secretário-adjunto da Segurança Pública, um sociólogo da Fundação Seade (Sistema Estadual de Análise de Dados), representantes da sociedade civil,

\footnotetext{
${ }^{41} \mathrm{O}$ "Coronel Ubiratan" foi o comandante da invasão da Polícia Militar de São Paulo ao Complexo Penitenciário do Carandiru, em 1992, ocasião em que morreram 111 detentos, no trágico caso que ficou conhecido como "massacre do Carandiru". O coronel foi morto em seu apartamento em São Paulo.

${ }^{42}$ Reunião Conseg Perdizes/Pacaembu, sede da SABESP, 20/08/2013.
} 
especialistas de universidades, dos Consegs (Conselhos Comunitários de Segurança) e das Polícias Civil, Militar e Técnico-Científica ${ }^{43}$. Acontece que os Consegs seriam representados pelo coordenador estadual, aquele que é escolhido pelo governador, como informado anteriormente. Na reunião do Conseg de Perdizes/Pacaembu do mês que se seguiu a esse anúncio o presidente manifestou insatisfação sobre o "grupo de estudos formado pela Secretaria de Segurança Pública". Sobre a iniciativa, o presidente mostrou-se crítico uma vez que o anúncio era da participação dos Consegs e apenas o coordenador faria parte sem que nenhum membro das dezenas de conselhos da cidade tivesse sido consultado.

${ }^{43}$ http://www.ssp.sp.gov.br/noticia/lenoticia.aspx?id=31902 


\section{ANÁLISES E RESULTADOS}

\subsection{Qual a relação dos atores da política formal com os participantes dos Consegs?}

Em uma das reuniões observadas ${ }^{44}$, o presidente fez um agradecimento à vereadora Edir Sales (PSD) pela limpeza de um parque da região após a demanda ter sido encaminhada a ela através do Conseg. Na reunião seguinte ${ }^{45}$, de posse da nova diretoria do mesmo Conseg, havia nada menos que cinco pessoas que me foram indicadas (e com duas delas tive oportunidade de confirmar a informação) como assessores dessa mesma vereadora. Nessa reunião de posse também esteve presente o vereador Toninho Vespoli (Psol) e em conversa paralela me foi dito que a vereadora Juliana Cardoso (PT) também costumava mandar representantes. Esse exemplo ilustra a inserção dos vereadores no Conseg - um dos sentidos de uma via de mão dupla que poderia ser vista como um sistema de dádivas, como percebeu Moraes (2011). Mas a explicação pretendida aqui é mais tangível do que um sistema social. A aproximação entre vereadores e membros do Conseg, coloca sim em marcha uma sequência de trocas, mas trocas que são mais pragmáticas, conscientes e interessadas.

Nesse contexto teórico, a noção de atores institucionalmente inseridos ou, se preferir, institucionalmente permeados (institutionally embeded), sugere que são os atores que estabelecem vínculos com atores políticos institucionais - no contexto do Brasil, partidos políticos, movimentos sindicais, grupos religiosos organizados e o Estado - que têm a capacidade de alcançar e se engajar nas novas instituições de participação cidadã. (Houtzager, Gurza Lavalle e Acharya, 2004, pg. 267).

Do lado dos vereadores, esses agregam legitimidade para seus projetos de lei ao reivindicarem que falam em nome dos membros do Conseg $X$ ou $Y$, ao alegar que sabem o que quer a "sociedade civil" e garantindo que aqui e ali as benfeitorias realizadas no bairro com a sua ajuda possam ser anunciadas nas reuniões. Do lado dos membros do Conseg, a relação com os vereadores Ihes garante visibilidade nos circuitos da política formal, marcando posição e no mínimo, garantindo que não se tornem irrelevantes ou dispensáveis no tempo. No máximo, podem tentar ampliar as atribuições dos Consegs e sua relevância na área da política de segurança pública, como de fato acontece de tempos em tempos, tanto no âmbito municipal, como no âmbito do legislativo estadual, quando esses vereadores tornam-se deputados.

\footnotetext{
${ }^{44}$ Reunião observada: Conseg Sapopemba, 28/05/2013, Salão de Festas Kiloco.

${ }^{45}$ Reunião observada: Conseg Sapopemba, 25/06/2013, Salão de Festas Serafin's.
} 
A aproximação dos Consegs com atores políticos institucionais será medida pela relação com o legislativo, mais especificamente com os vereadores, que é voluntária. Não faria sentido medir esse tipo de relação com membros do poder executivo já que estes estão ligados ao Conseg por definição normativa.

Nas atas de reunião pesquisadas, $28 \%$ (34 em 120) mencionavam a presença de um representante do legislativo (majoritariamente vereadores) ou de um assessor. Não foi possível estabelecer de forma confiável (ou negar de forma confiável) qualquer associação entre a presença de um vereador ou assessor e o nível de satisfação dos cidadãos nos Consegs (os testes estatísticos com essa variável serão analisados no item 4.2).

A maior parte dos vereadores com relação relevante com Consegs (vamos chamar aqui vereadores relacionados e logo no próximo parágrafo explica-se o que se entendeu por relações relevantes), têm redutos eleitorais bem delimitados em certas regiões da cidade, o que pode explicar a participação de parte deles já que o Conseg permite uma interface com eleitores, tanto moradores quanto lideranças comunitárias. Um número menor de vereadores relacionados se posiciona mais fortemente por área de política e a relação desses com os Consegs é menos associada às regiões de reduto eleitoral.

Para demonstrar esse ponto, a próxima sessão traz uma relação de vereadores relacionados, ou seja, que se destacaram na pesquisa por aparecerem pelo menos em três reuniões na amostragem das atas, ou por aparecerem muitas vezes mencionando os Consegs na atividade legislativa. Informações da atuação na Câmara dos Vereadores (obtidas no Diário Oficial do Município, pesquisado entre os anos de 2003 e $2013^{46}$ ), da amostragem das atas das reuniões e das reuniões observadas foram comparadas às informações sobre quais locais esses vereadores obtiveram o maior número de votos. Se a análise das atas pelo método amostral pode ter deixado de captar casos de vereadores muito atuantes em Consegs de determinadas regiões, dificilmente essa relação escaparia também à pesquisa exaustiva no DOM-SP. Com esses dados é possível demonstrar a existência de uma relação de certos vereadores com os Consegs que se estende no tempo e a natureza dessa relação que pode se dar em bases territoriais, por área de política ou ainda com base em ambas. Nos mapas a seguir, as setas indicam os Consegs com os quais o vereador(a) parece ter relação (informação das atas ou das atividades na Câmara) e as estrelas

\footnotetext{
${ }^{46}$ Para essa análise especificamente as sessões solenes não foram contabilizadas pois eram muito numerosas e o ponto que quero demonstrar pode suficientemente ser demonstrado com as outras ocorrências. Elas no entanto serão analisadas adiante para checar a presença de membros dos Consegs na Câmara.
} 
indicam as zonas eleitorais da cidade em que foi mais votado ${ }^{47}$. Essa atuação não está separada por legislaturas e cobre o período de janeiro de 2003 e março de 2013.

\section{Adilson Amadeu - PTB}

Apresentou um projeto de lei para a mudança de nome de uma praça por solicitação do Conseg Alto da Mooca em 2010 e fez duas referências na Câmara ao Conseg Mooca (2008 e 2013). As zonas eleitorais onde o vereador (eleito por coeficiente partidário) obteve maior número de votos em 2012 foram: São Miguel Paulista, Vila Curuça, Itaim Paulista (três bairros contíguos em direção ao extremo leste da cidade de São Paulo) e Mooca. Entre todos os vereadores relacionados na pesquisa, Amadeu foi o único para o qual não foi encontrada consistentemente nem coincidência entre área de votação e relação com os Consegs da região e nem afinidade por área de política (projetos na área de segurança pública).

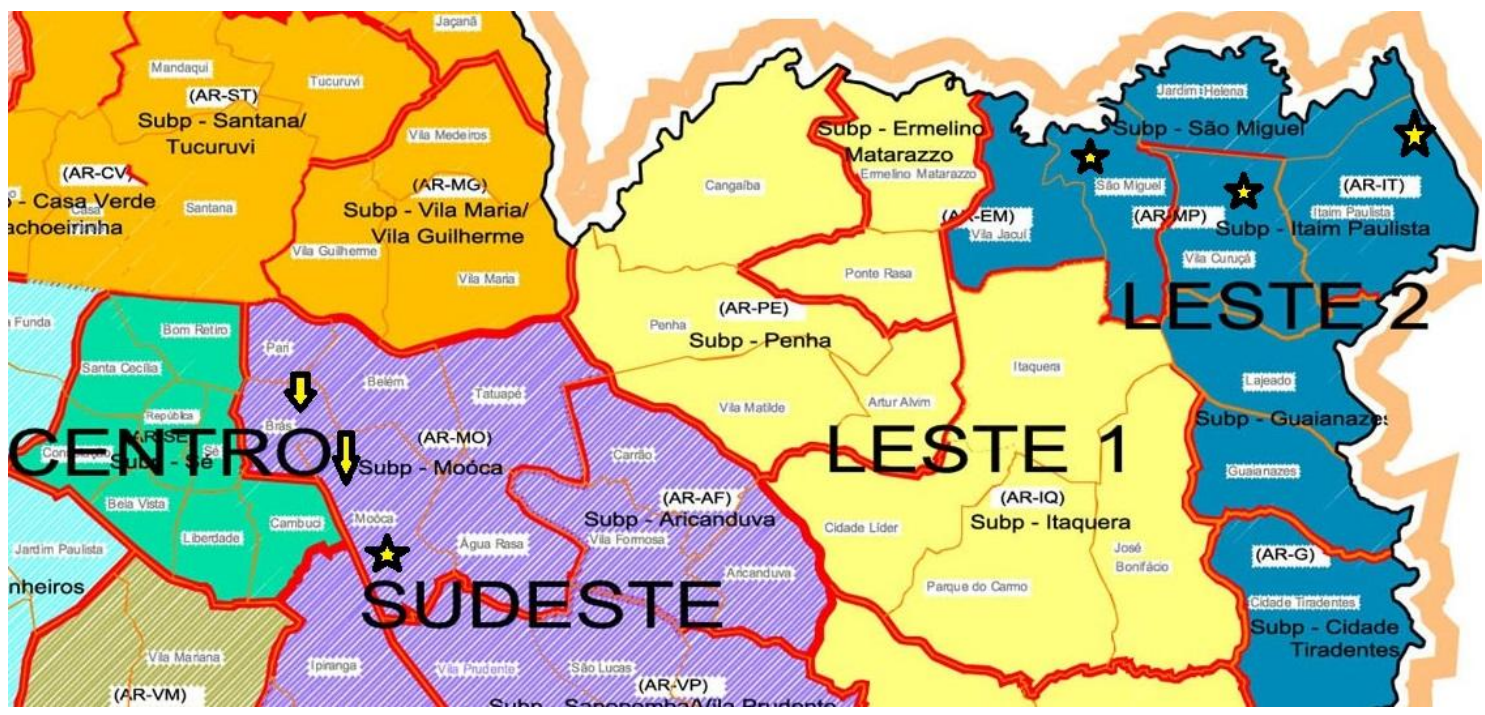

Figura 1 - Elaboração própria baseada nas atividades relacionadas ao Conseg (atas das reuniões e informações do DOM-SP) X reduto eleitoral do vereador Adilson Amadeu (ZEs onde obteve maior votação, segundo TSE)

\section{Antônio Goulart - PMDB}

Apresentou um projeto de lei em 2003 que visava a modificar a lei que regulamenta o fechamento de ruas e vielas sem saída, acrescentando como uma condição para obter a autorização de fechamento: um atestado do Conselho Comunitário de Segurança de que se tratava de local com

\footnotetext{
${ }^{47}$ Os estrelas que indicam a zona eleitoral de maior votação estão dentro da unidade territorial definida pela justiça eleitoral, mas a localização do ícone dentro do desenho da unidade administrativa é aproximada.
} 
risco de crimes. Em 2012 apresentou um projeto de decreto legislativo para outorga da Medalha Anchieta e Diploma de Gratidão da Cidade de São Paulo ao um determinado cidadão que, entre outros feitos, era membro do Conselho Comunitário de Segurança de Parelheiros (zona sul da cidade). $\mathrm{Na}$ amostragem das atas, seu nome aparece como estando presente ou representado nas reuniões de Campo Grande e Campo Belo (ambos na região centro-sul). Em plenária faz algumas afirmações sobre sua atuação com o Conseg: em 26/08/2003 ${ }^{48}$ afirmou: "sou o vereador que tem uma atuação mais organizada na zona Sul da Cidade e tenho participado assiduamente das reuniões de todos os Consegs de nossa região"; em 2007 refere-se a sua batalha para a criação da 5a Companhia [da PM] na região de Santo Amaro junto com o Conseg local ${ }^{49}$. Em 2009 participa de debate sobre o fechamento da carceragem no 101 DP, Jardim das Imbuias (ou Grajaú), demandado pelo respectivo Conseg ${ }^{50}$. Também em 2009 requere um voto de júbilo e congratulação com o Conseg de Santo Amaro. Zonas eleitorais onde o vereador obteve maior número de votos: Jardim Prudência (distrito de Cidade Ademar), Capela do Socorro, Pedreira, Cidade Dutra e Parelheiros.

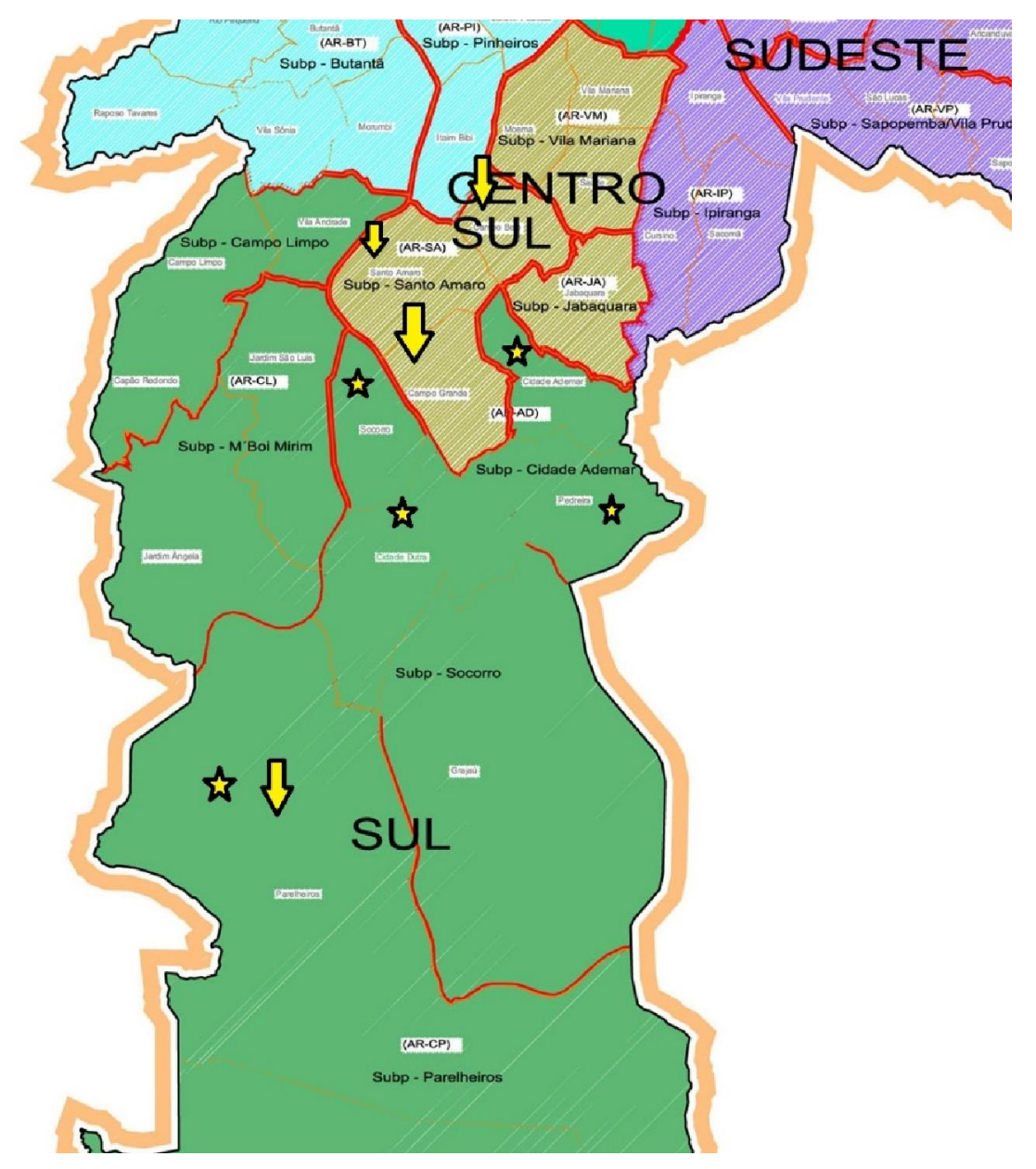

\footnotetext{
${ }^{48} 254$ Sessão Ordinária

49 315 a SESSÃO ORDINÁRIA 04/12/2007

50 18a SESSÃO EXTRAORDINÁRIA 1인/2009
} 
Figura 2 - Elaboração própria baseada nas atividades relacionadas ao Conseg (atas das reuniões e informações do DOM-SP) X reduto eleitoral do vereador Antônio Goulart (ZEs onde obteve maior votação, segundo TSE)

\section{Claudinho de Souza - PSDB}

O vereador apresentou três projetos de lei para nomear espaços públicos envolvendo Consegs. Um teria sido encaminhamento a pedido do Conseg Santa Maria/Limão ${ }^{51}$ e dois davam aos espaços o nome de uma personalidade importante na região, incluindo na biografia dos homenageados a participação nos Consegs de Vila Amália (distrito de Casa Verde) ${ }^{52}$ e Freguesia do $\mathrm{O}^{53}$. Na amostragem das atas, o vereador/assessor aparece duas vezes no Conseg da Freguesia do Ó. Em 2012 Souza registra a presença do Presidente do Conseg da Freguesia do Ó em uma sessão ${ }^{54}$. Em 2007 faz uma fala na tribuna sobre um prêmio recebido pela delegacia da Vila Brasilândia como melhor delegacia da cidade e menciona o presidente do Conseg do distrito ${ }^{55}$. Em 27/09/2011 anuncia naquela mesma noite estaria presente na reunião do Conseg do 40ㅇ DP (Vila Santa Maria/Limão), para levar a notícia do início da canalização de um córrego. Zonas eleitorais onde teve maior votação: Lapa, Pirituba, Casa Verde, Freguesia do Ó e Brasilândia. Os Consegs com os quais o vereador mantém relações bem como os locais onde ele obteve maior votação formam uma área contígua na tríplice fronteira entre as regiões oeste, nordeste e noroeste da cidade.

\footnotetext{
${ }^{51}$ PROJETO DE LEI 01-00119/2012

${ }^{52}$ PROJETO DE LEI 01-00213/2012

${ }^{53}$ PROJETO DE LEI 01-00533/2012

${ }^{54}$ 375a SESSÃO ORDINÁRIA 09/08/2012

${ }^{55}$ 282a SESSÃO ORDINÁRIA 06/09/2007
} 


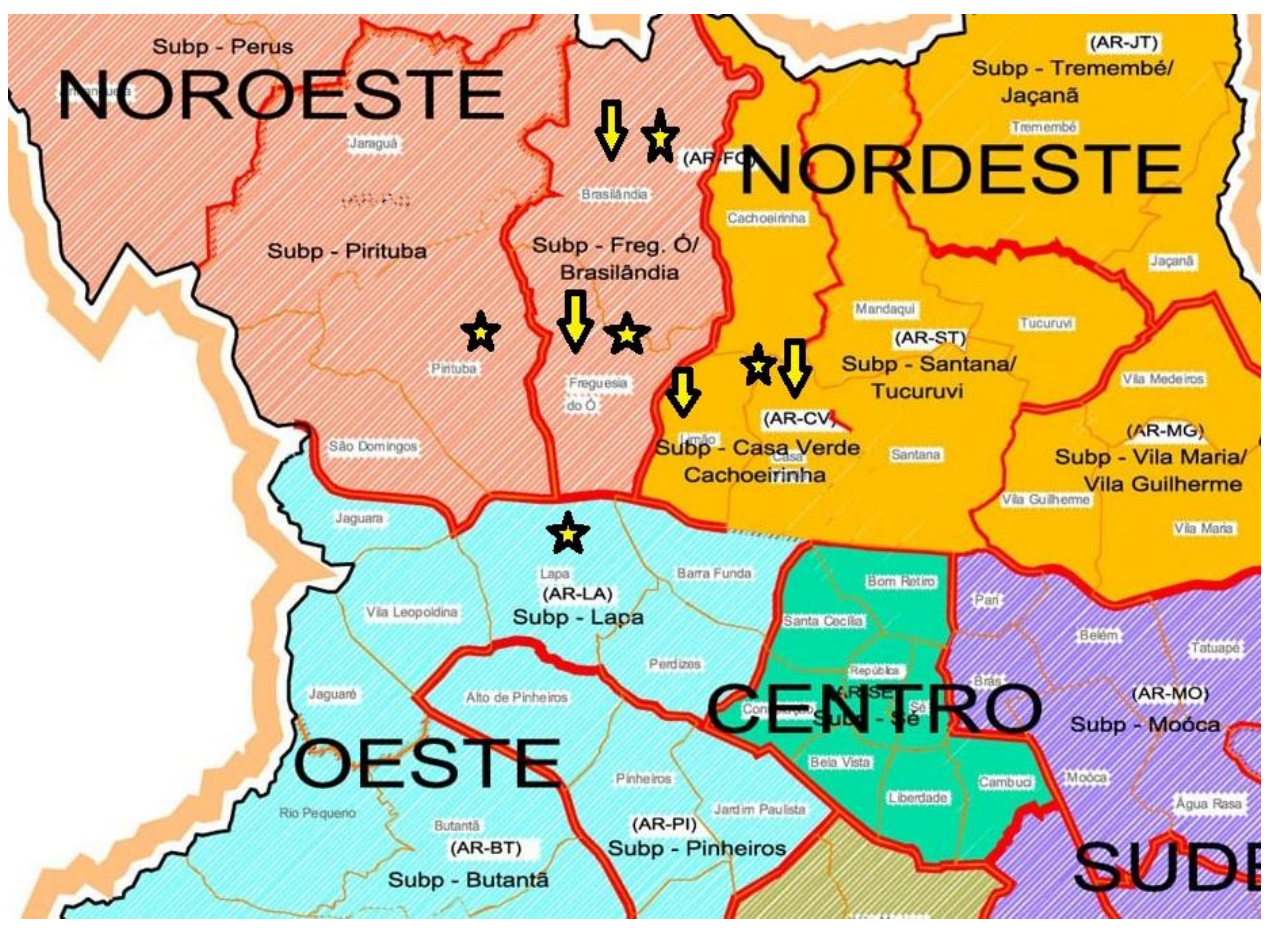

Figura 3 - Elaboração própria baseada nas atividades relacionadas ao Conseg (atas das reuniões e informações do DOM-SP) X reduto eleitoral do vereador Claudinho de Souza (ZEs onde obteve maior votação, segundo TSE)

\section{Domingos Dissei - PSD}

$\mathrm{Na}$ amostragem de atas reunidas para a pesquisa, constava a presença do vereador e/ou assessor em cinco reuniões de Consegs: no Cambuci, Vila Clementino (bairro do distrito de Vila Mariana), Ipiranga, Sacomã e Parque Bristol (bairro do distrito de Sacomã). Todos esses bairros foram uma faixa contínua atravessando as regiões do centro, centro-sul e sudeste. ZEs de maior votação em $2008^{56}$ : Ipiranga, Cursino, Saúde e Vila Clementino.

\footnotetext{
${ }^{56}$ Domingos Dissei não participou da eleição para vereador em 2012 por isso a votação considerada foi a de 2008.
} 


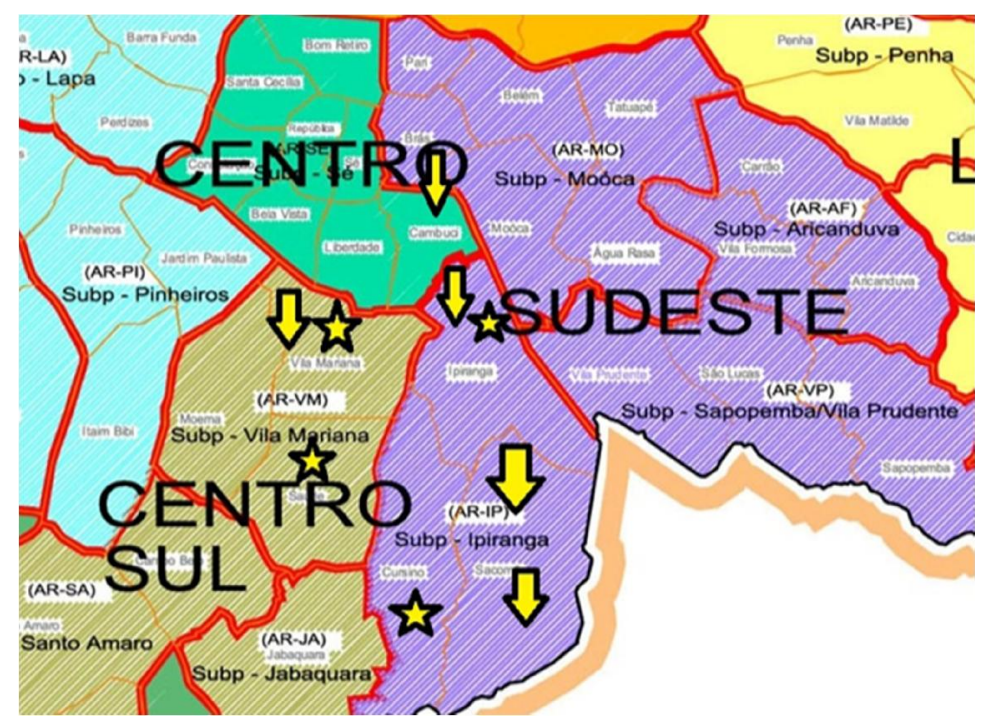

Figura 4 - Elaboração própria baseada nas atividades relacionadas ao Conseg (atas das reuniões e informações do DOM-SP) X reduto eleitoral do vereador Domingos Dissei (ZEs onde obteve maior votação, segundo TSE)

\section{Edir Sales - PSD}

Nas atas da amostragem, a presença da vereadora/assessor é registrada em reunião no Parque São Lucas e São Miguel Paulista. Em 28 de maio de 2013 a vereadora recebeu agradecimentos na reunião do Conseg Sapopemba. Na reunião seguinte, de posse da nova diretoria estavam presentes cinco de seus assessores (ver início desse capítulo). Nos registros das sessões da câmara constam votos de júbilo e congratulação com os Consegs de Vila Prudente e São Mateus, ambos em $2012^{57}$. Em sessão de 22 de novembro de 2012, anuncia a homenagem que iria receber no Conseg 29ㅇ, "do Presidente Rogério", juntamente com "o Delegado Charles Calil, da 29a DP" (Vlia Diva). Suas zonas eleitorais de maior votação foram, em 2012, Vila Prudente, Sapopemba e Teotônio Vilela (distrito de Sapopemba), demonstrando que sua atuação nos Consegs coincide com seu reduto eleitoral em um estreita área na zona leste de São Paulo.

${ }^{57}$ EXPEDIENTE - 369a SO 


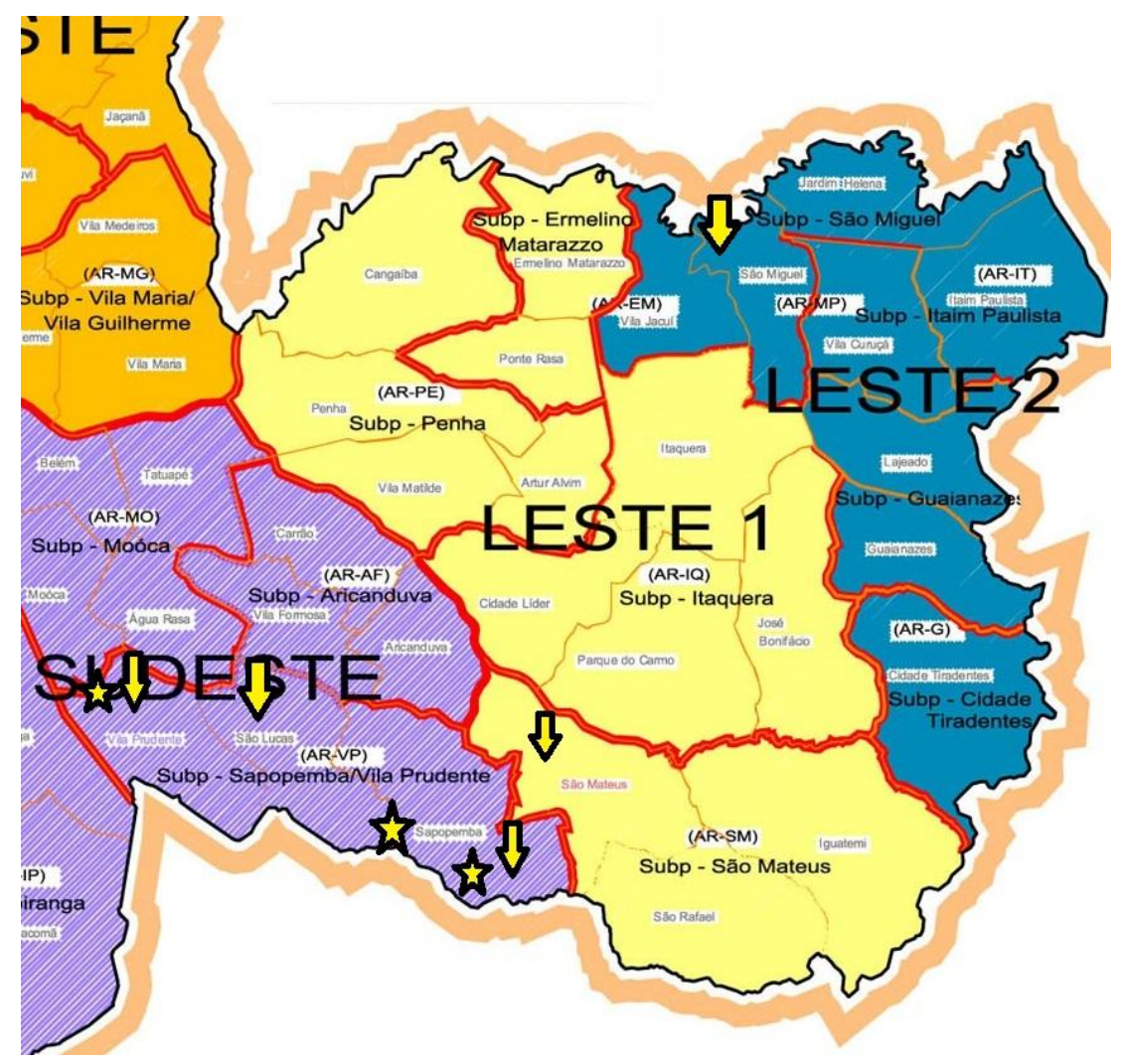

Figura 5 - Elaboração própria baseada nas atividades relacionadas ao Conseg (atas das reuniões e informações do DOM-SP) X reduto eleitoral da vereadora Edir Sales (ZEs onde obteve maior votação, segundo TSE).

\section{Gilberto Natalini - PSDB/PV}

Nas atas dos Consegs consta sua presença/de assessor em duas reuniões em Cidade Ademar e uma reunião em Santo Amaro. Constam dois requerimentos de voto de júbilo com Conseg de sua autoria: Santo Amaro e Lapa. Em 2012 obteve as mais expressivas votações nas ZEs de Indianópolis (bairro do distrito de Moema), Santo Amaro, Cangaíba e Pedreira. Com exceção das menções a Lapa (zona oeste) e ao bairro de Cangaíba (extremo leste), as outras referência são sobre bairros na zona sul da cidade, com composição de renda variada. As evidências de correspondência territorial existem, mas certamente não são tão fortes como a de outros vereadores. 


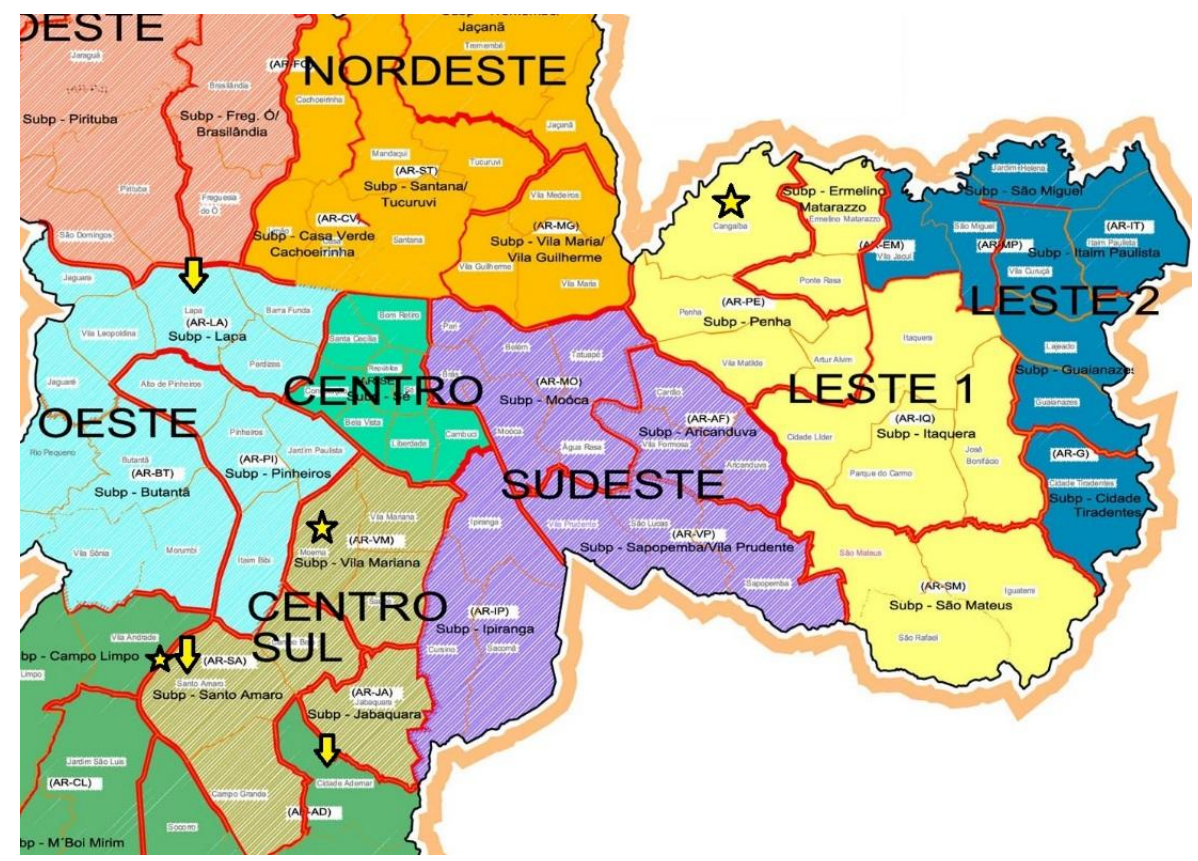

Figura 6 - Elaboração própria baseada nas atividades relacionadas ao Conseg (atas das reuniões e informações do DOM-SP) X reduto eleitoral do vereador Gilberto Natalini (ZEs onde obteve maior votação, segundo TSE).

\section{Toninho Paiva - PL}

Toninho Paiva parece ser um vereador bastante presente junto aos Consegs. $\mathrm{Na}$ amostragem de atas ele e/ou assessor aparecem em reuniões no Tatuapé (duas vezes), na Penha (duas vezes), Vila Matilde (duas vezes) e Artur Alvim, todos bairros contíguos na zona leste da cidade. Na Câmara estão registrados requerimentos seus de voto de jubilo e congratulações com os Consegs do Centro (2003), Mooca (2003), Parque São Jorge (distrito Tatuapé) (2003, 2006, 2007), Vila Prudente (2005), Vila Matilde (2008), Tatuapé (2007, 2009), Penha (2009) ${ }^{58}$. Em 2005, ao defender o rebaixamento da maioridade penal para 16 anos $^{59}$, pede que cópia de seu discurso seja enviada para o Conseg do bairro do Belém, também na mesma região. No mesmo ano, faz um elogio ao presidente do Conseg de Vila Matilde, presidente que seria "por demais atuante" ${ }^{\prime 60}$. Todos esses bairros citados, juntos formam uma faixa contigua do centro em direção à zona leste. As Zonas eleitorais onde o vereador obteve o maior número de votos em 2012 foram: Vila Azevedo (distrito

\footnotetext{
${ }^{58}$ 25/11/03 EXPEDIENTE DESPACHADO PELA PRESIDÊNCIA; 2003 EXPEDIENTE - 253a SO; 30/10/2003 EXPEDIENTE - 275a SO; 10/05/2006 EXPEDIENTE - 147a SO; 2007 EXPEDIENTE - 262a SO; 2005 EXPEDIENTE 53a SO; 2008 EXPEDIENTE - 369a SO; 2009 EXPEDIENTE - 46a SO; 2007 EXPEDIENTE - 256a SO. Diário Oficial do Município http://www.imprensaoficial.com.br/ Acessado entre março e maio de 2013.

${ }^{59}$ 18a SESSÃO ORDINÁRIA 16/03/2005. Diário Oficial do Município http://www.imprensaoficial.com.br/ Acessado entre março e maio de 2013.

${ }^{60}$ Diário Oficial do Município de São Paulo de 01-09-2005 Página 95. http://www.imprensaoficial.com.br/ Acessado entre março e maio de 2013.
} 
do Tatuapé, zona leste), Vila Nova Savoia (Vila Matilde), Cagaíba (Subprefeitura da Penha), Vila Esperança (Subprefeitura Penha) e Ponte Rasa (Subprefeitura de Ermelino Matarazzo).

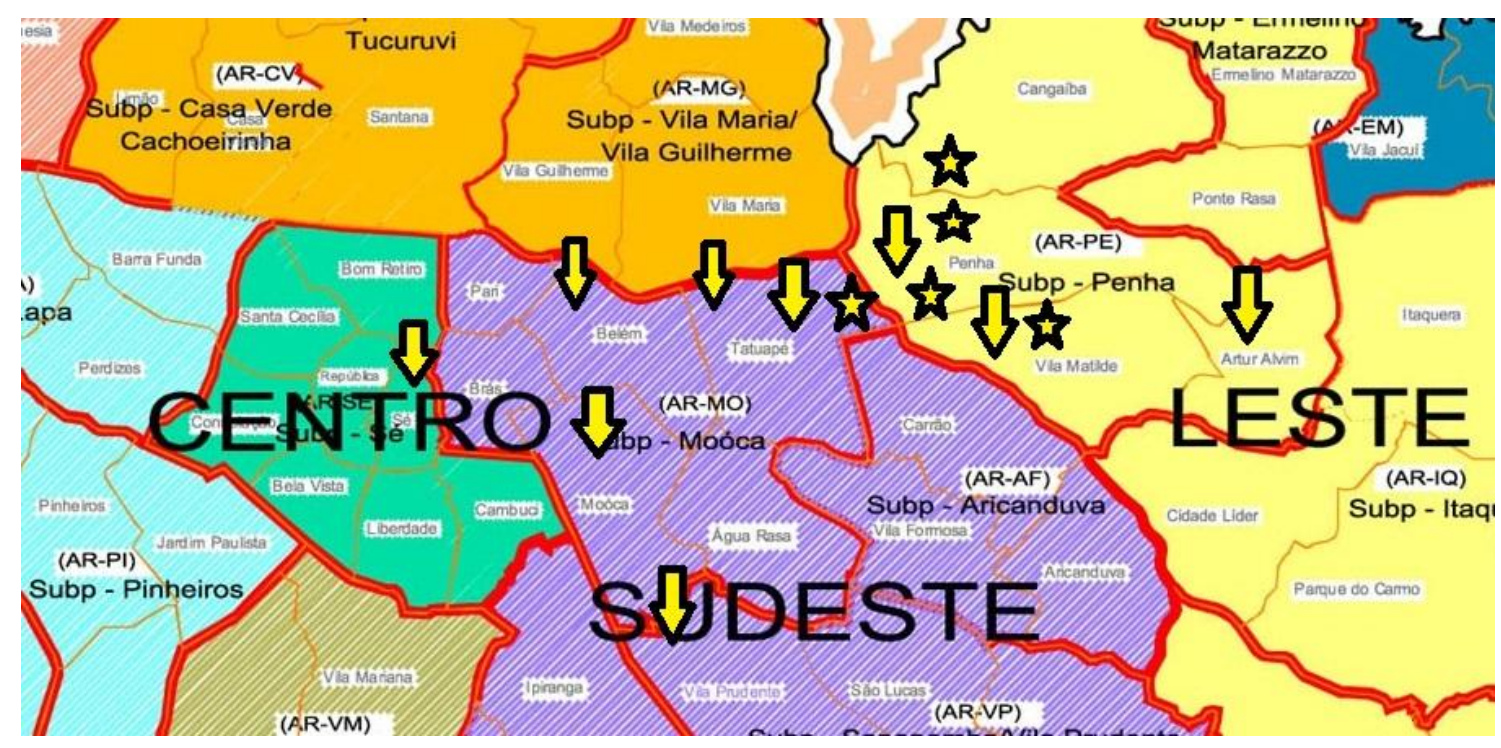

Figura 7 - Elaboração própria baseada nas atividades relacionadas ao Conseg (atas das reuniões e informações do DOM-SP) X reduto eleitoral do vereador Toninho Paiva (ZEs onde obteve maior votação, segundo TSE).

\section{Wadih Mutran - PP/PFL}

Em 2007 o vereador entrou com um projeto de lei visando à concessão de auxíliotransporte, na forma de carteirinhas de transporte gratuito, a todos os Presidentes de entidades assistenciais, associações, Consegs e demais instituições localizadas no Município de São Paulo. Embora essa seja uma lei em que o Conseg aparece apenas de forma secundária, o vereador parece ter relações, ou pretender tê-las, com Consegs na zona norte da cidade. Requereu em sessões ordinárias, voto de Jubilo com os Consegs: Parque Novo Mundo (2003, 2004, 2005, 2006, 2007 e

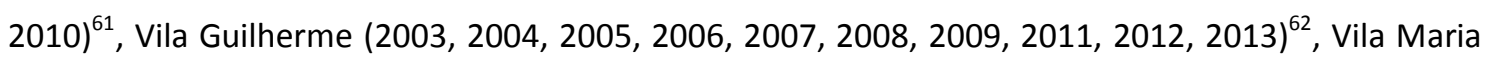
$(2005)^{63}$, Santa Cecília $(2004)^{64}$, Jaçanã $(2005)^{65}$ e Água Fria $(2005)^{66}$. Com exceção de Santa Cecília,

\footnotetext{
${ }^{61} 2003$ EXPEDIENTE - 250a SO; EXPEDIENTE DESPACHADO PELA PRESIDÊNCIA EM 06/11/03; 2004 EXPEDIENTE - 353a SO; 2005 Requerimento 13-1913/05; 2005 EXPEDIENTE - 54a SO; 2006 EXPEDIENTE - 186a SO; 2007 Requerimentos 13-2285/07; EXPEDIENTE - 196a SO 17/11/2010. Diário Oficial do Município de São Paulo http://www.imprensaoficial.com.br/ Acessado entre março e maio de 2013.

${ }^{62} 2003$ EXPEDIENTE - 214a; 2004 EXPEDIENTE - 298a SO; 2004 EXPEDIENTE - 342a SO; 2004 EXPEDIENTE - 342a SO; 2005 EXPEDIENTE - 12a SO; 2006 EXPEDIENTE - 177a SO ; 2007, EXPEDIENTE - 220a SO; 2008 EXPEDIENTE -

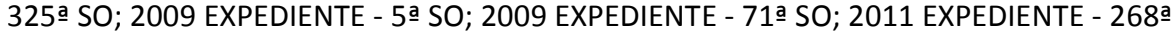

${ }^{63} 2005$ EXPEDIENTE - 43a SO

${ }^{64} 2004$ EXPEDIENTE - 342a SO

${ }^{65} 2005$ EXPEDIENTE - 54a SO

${ }^{66} 2005$ EXPEDIENTE - 66ㅇ SO
} 
são todos bairros da zona nordeste da cidade, mesmos lugares onde se encontram as zonas eleitorais onde o vereador obteve o maior número de votos em $2012^{67}$ : Vila Maria, Tremembé, Jaçanã e Vila Sabrina (bairro situado em vila Medeiros, também na zona noroeste).

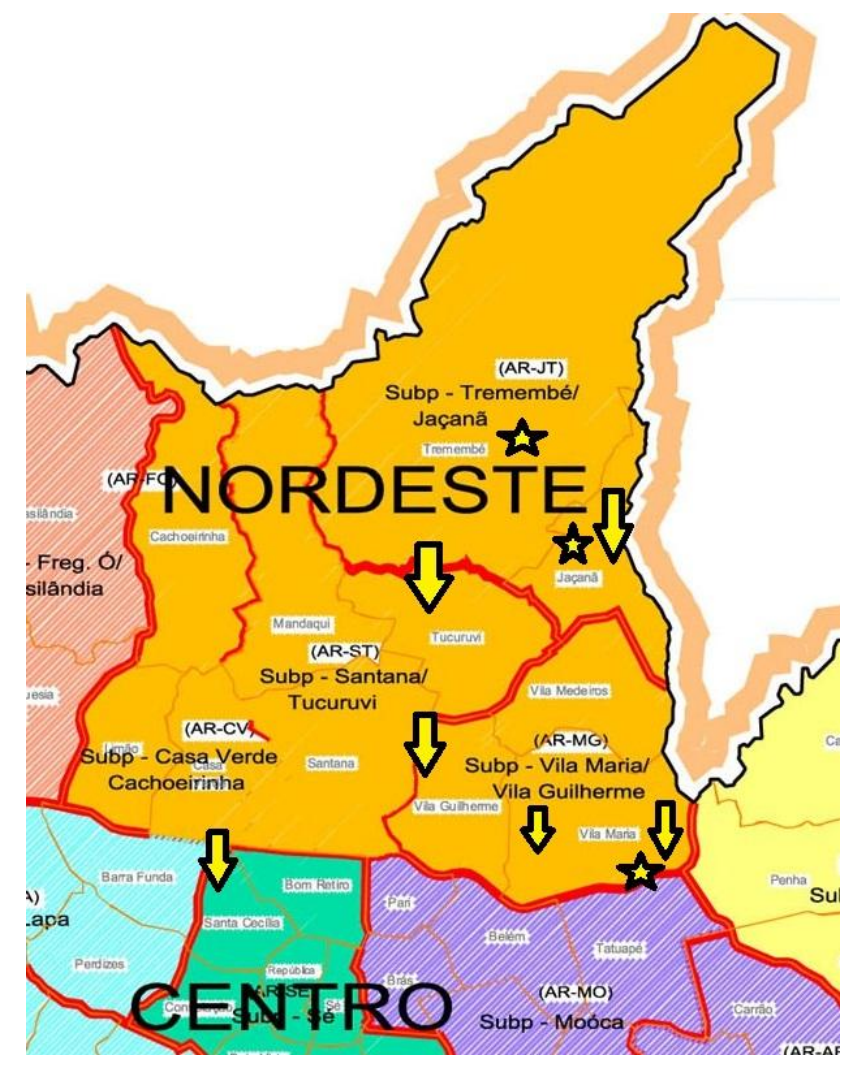

Figura 8 - Elaboração própria baseada nas atividades relacionadas ao Conseg (atas das reuniões e informações do DOM-SP) X reduto eleitoral do vereador Wadih Mutran (ZEs onde obteve maior votação, segundo TSE).

\section{Ricardo Teixeira - PSDB/PV}

Antes de ser vereador, Teixeira, engenheiro de formação, trabalhou na CET - Companhia de Engenharia de Tráfego de São Paulo; na EMTU - Empresa Metropolitana de Transportes Urbanos, DERSA- Desenvolvimento Rodoviário S.A e DER - Departamento de Estradas de Rodagem de SP. Não parece acidental que tenha sido o autor de uma lei visando a assegurar a participação de representantes da CET, nos Conselhos Comunitários de Segurança (LEI № 14.901). Na amostragem das atas, consta que o vereador e/ou assessor estiveram presentes em reunião nos Consegs: Braz/Mooca Belenzinho, Vila Maria e Vila Prudente. Zonas de votação Mooca, Vila Curuça, Itaim Paulista. Tanto as referências à presença do vereador em Consegs como as ZEs onde ele foi mais votado apresentam uma diversificação que não permite inferir uma relação baseada em

\footnotetext{
${ }^{67}$ Nesta eleição tornou-se vereador como suplente.
} 
territorialidade. Considerando-se sua carreira e área de atuação legislativa, parece que sua relação com os Consegs está mais baseada na área de política.

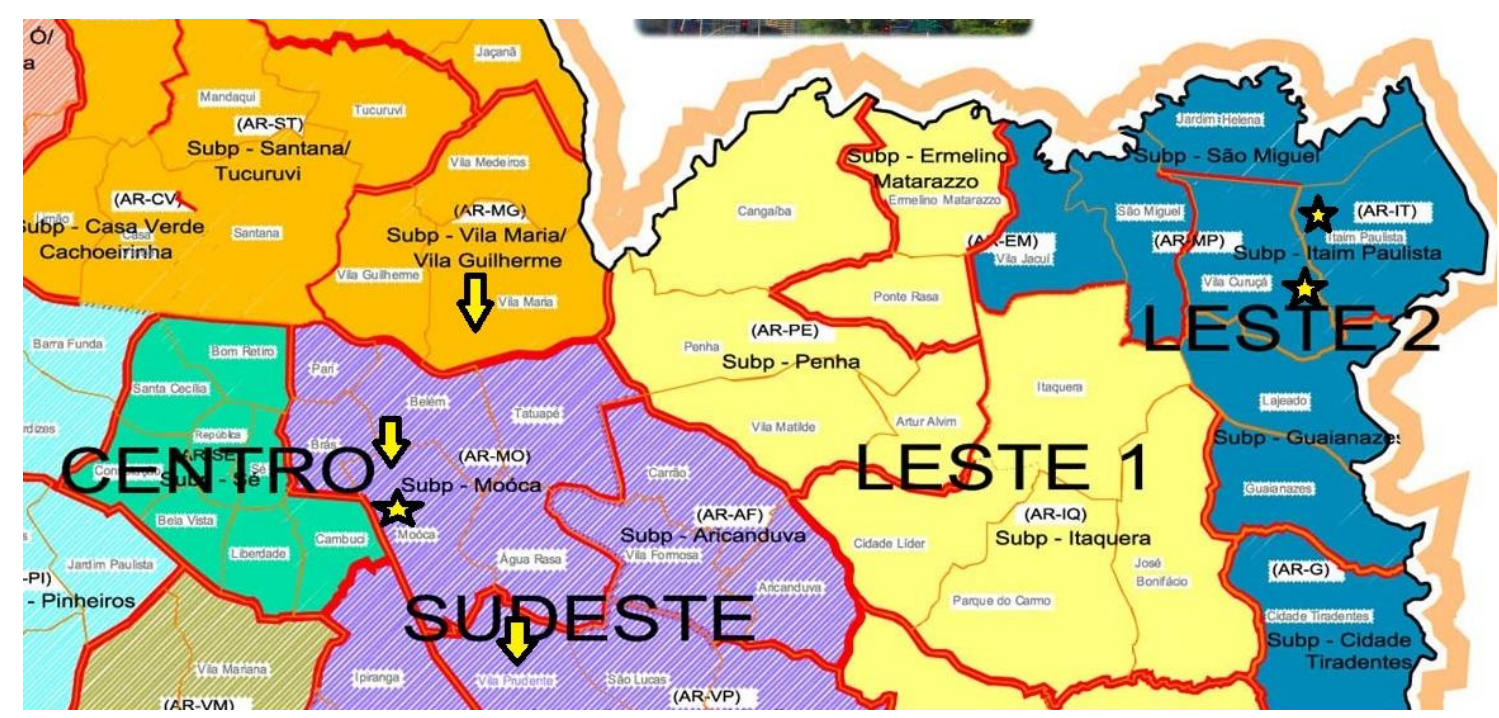

Figura 9 - Elaboração própria baseada nas atividades relacionadas ao Conseg (atas das reuniões e informações do DOM-SP) X reduto eleitoral do vereador Ricardo Teixeira (ZEs onde obteve maior votação, segundo TSE).

\section{Jooji Hato - PMDB}

O vereador e depois deputado parece ter uma relação híbrida com os Consegs que é territorial, mas também por área de política. Na Câmara de São Paulo em 2006 falou em defesa do presidente do Conseg Monções/Brooklin e os problemas de perturbação no sono ${ }^{68}$ (o vereador foi autor de uma lei aprovada em 1999 obrigando os bares sem isolamento acústico apropriado a encerrarem suas atividades até $1 \mathrm{~h}$ da manhã). Em 2008, aborda o mesmo assunto em plenário, dessa vez anunciando que esteve em reunião no Conseg Tatuapé para tratar do tema ${ }^{69}$. Sobre o Conseg do Tatuapé, fala também em 2009, parabenizando os esforços da diretoria em fazer cumprir a lei seca $^{70}$ proibindo a venda de bebidas alcoólicas em postos de combustíveis e lojas de conveniência. Sua ligação com os Consegs parece ter começado em torno da campanha que realizou pela aprovação do projeto da "lei seca" municipal. Outro projeto de lei que parece ter mobilizado ainda vereador em torno dos Consegs foi o projeto que visava a proibir que motociclistas circulassem com pessoa como carona. Um tanto radical, o projeto de lei foi motivado pelas ocorrências de assaltos realizados por duplas em motocicletas. Já deputado estadual, em várias

\footnotetext{
${ }^{68}$ Diário Oficial do Município de SP, 07-06-06 pg. 73.

${ }^{69}$ Diário Oficial do Município de SP, 13-12-08 pg. 102.

${ }^{70}$ Diário Oficial do Município de SP, 15-10-09, pg. 181 e 183.
} 
oportunidades declarou nas sessões da ALESP ter ido a reuniões ou conversado com presidentes de Consegs, inclusive para obter apoio ao projeto de lei seca, que os presidentes do Conseg teriam ajudado a aprovar enquanto ele era vereador, sendo que um dos seus primeiros projetos na Assembleia Legislativa foi uma versão estadual da mesma lei. Algumas de suas falas referem-se a Consegs específicos, sendo eles: Liberdade, Itaim Bibi, Pinheiros, Pacaembu, Saúde e Morumbi ${ }^{71}$. Na amostragem das atas aparece em reunião do Conseg Vila Clementino já cumprindo seu mandato como deputado. Para justificar a lei seca, recorre a suas ligações com os Consegs da Saúde ${ }^{72}$ e Vila Gumercindo (bairro do distrito de Vila Mariana) ${ }^{73}$. Levando em conta todos os Consegs para os quais temos evidências de que Jooji Hato tem relação, verifica-se que sua atuação compreende uma área mais ampla, menos restrita à questão territorial. No mesmo sentido, os bairros com que o vereador mantém relações são mais centrais e concentram moradores com maior poder aquisitivo, o que pode indicar uma ação de busca de apoio entre grupos com razoável capital político e social para sua expressiva atividade legislativa ${ }^{74}$.

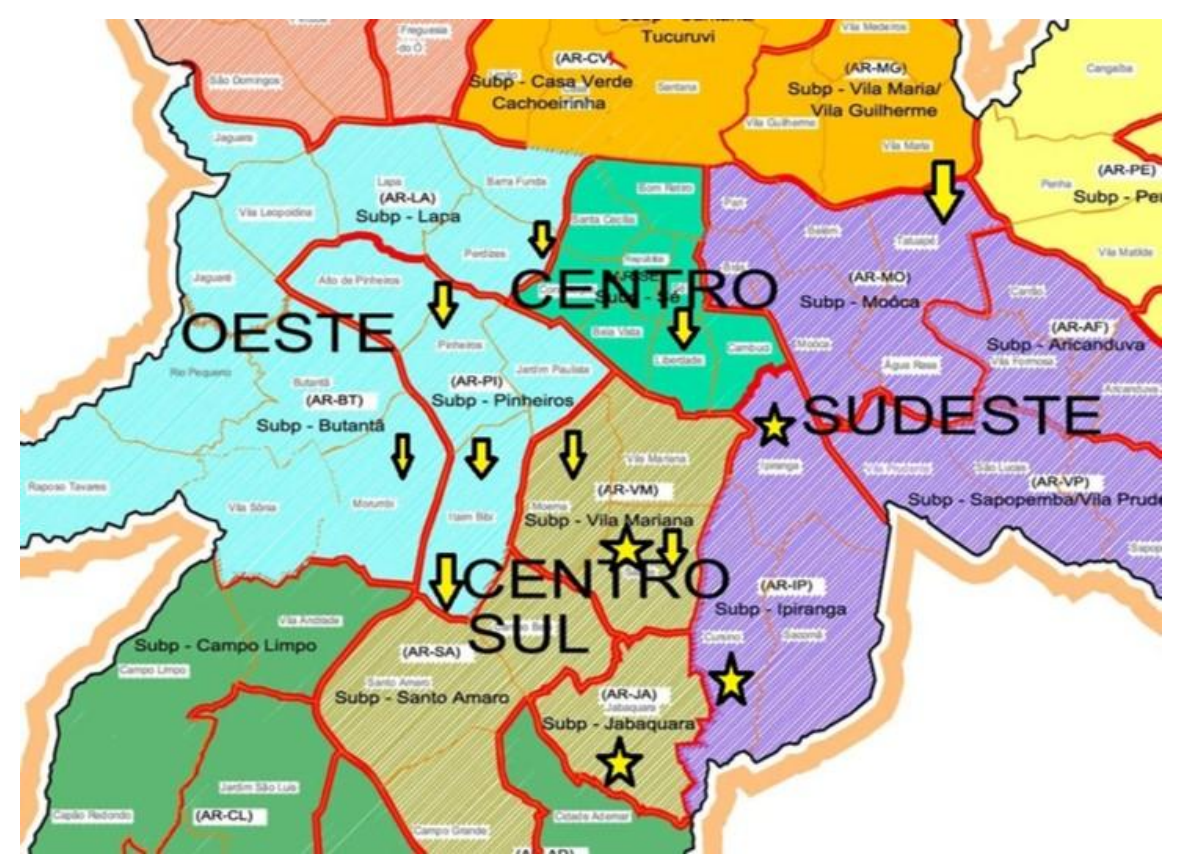

Figura 10 - Elaboração própria baseada nas atividades relacionadas ao Conseg (atas das reuniões e informações do DOM-SP) X reduto eleitoral do vereador Jooji Hato (ZEs onde obteve maior votação, segundo TSE).

\footnotetext{
${ }^{71}$ Oito menções aos Consegs entre 2011 e 2013. www.imprensaoficial.com.br=

72 Diário Oficial do Município SP 23-02-10, pg. 167.

${ }^{73}$ Diário Oficial do Município de SP 04-12-10, pg. 85.

${ }^{74}$ A página oficial do vereador na internet lista dezenas de projetos de lei e leis aprovadas relativa a temas como meio ambiente, saúde e infraestrutura urbana.
} 


\section{William Woo - PSDB e PPS}

Vereador entre 2001 e 2007. Como vereador fez requerimentos para votos de jubilo para dezenas de Consegs, sem aparente relação de territorialidade: Parque São Jorge $(2005,2006)$; Parque São Rafael (2002, 2003), Vila Amália (2203), Campo Belo (2003), Água Fria, Santa Cecília, Heliópolis, Belém, Jardim São Luiz (2003), São Mateus, Morumbi, Bom Retiro (2004, 2005), Portal do Morumbi (2004), Cambuci (2005) Pinheiros, Paraíso, Raposo Tavares, Butantã, Campo Grande, Bom Retiro, Bela Vista / Bexiga (2005) Alto da Mooca (2006) ${ }^{75}$. Em sessão, mencionou diversos outros Consegs e a instituição dos conselhos de forma geral, geralmente em assuntos ligados a segurança pública, tal como quando participou de uma campanha para incentivar crianças a se desfazerem de armas de brinquedo ${ }^{76}$ e afirmou que participava semanalmente das reuniões do Conseg ${ }^{77}$. Foi um dos organizadores do III e do IV Encontro dos Consegs da Capital na Câmara ${ }^{78}$. Ex-policial civil, o vereador chegou a declarar na tribuna que "a polícia de São Paulo é a melhor polícia do mundo"79. Criou os projetos que resultaram nas leis municipais: 13.720/2004 regulamentando as atividades de cybercafés, visando especialmente regular a frequência de menores de idade; lei 13.418/2003 que dispõe sobre a obrigatoriedade da fixação de adesivos com o telefone do Disque Denúncia em ônibus urbanos municipais e também foi autor de um projeto de lei que visava a regulamentar a atividade de empresas de guarda e estacionamento de veículos (valets) - todos assuntos corriqueiros nas discussões dos Consegs. Aparece na amostragem das atas como estando representado e/ou pessoalmente em reuniões nos bairros do Ipiranga, Sacomã e Parque Bristol, não mais como vereador, mas já como deputado federal (2007-2011). Zonas eleitorais onde teve maior votação em 2004 ${ }^{80}$ : Saúde, Ipiranga, Ermelino Matarazo e Vila Clementino. A diversidade de Consegs com os quais manteve relações no período, sua carreira anterior como policial e o teor da atividade legislativa indicam um tipo de ligação com essas instituições mais baseada na área de política do que na territorialidade.

\footnotetext{
${ }^{75} 2006$ EXPEDIENTE - 174a SO; 19/12/2002 198a SESSÃO ORDINÁRIA; 2003 EXPEDIENTE - 276a SO; 2003 EXPEDIENTE - 251a SO; EXPEDIENTE DESPACHADO PELA PRESIDÊNCIA EM 17/12/03; EXPEDIENTE - 289a SO 17/12/2003; 2004 EXPEDIENTE - 297a SO; 2005 EXPEDIENTE - 87a SO; 2005 EXPEDIENTE - 68a SO; EXPEDIENTE 200a SO 08-11-2006. DOM-SP www.imprensaoficial.com.br Acessado entre março e maio de 2013.

${ }^{76}$ Diário Oficial do Município 24-09-03, pg. 117.

77 Diário Oficial do Município, 6-03-03, pg. 63.

78 308a SESSÃO ORDINÁRIA 14/04/2004, 165a SESSÃO ORDINÁRIA 01/08/2006

79 277a Sessão Ordinária da 13a Legislatura, 5 de novembro de 2003.

${ }^{80}$ Última eleição em que William Woo se candidatou a vereador.
} 


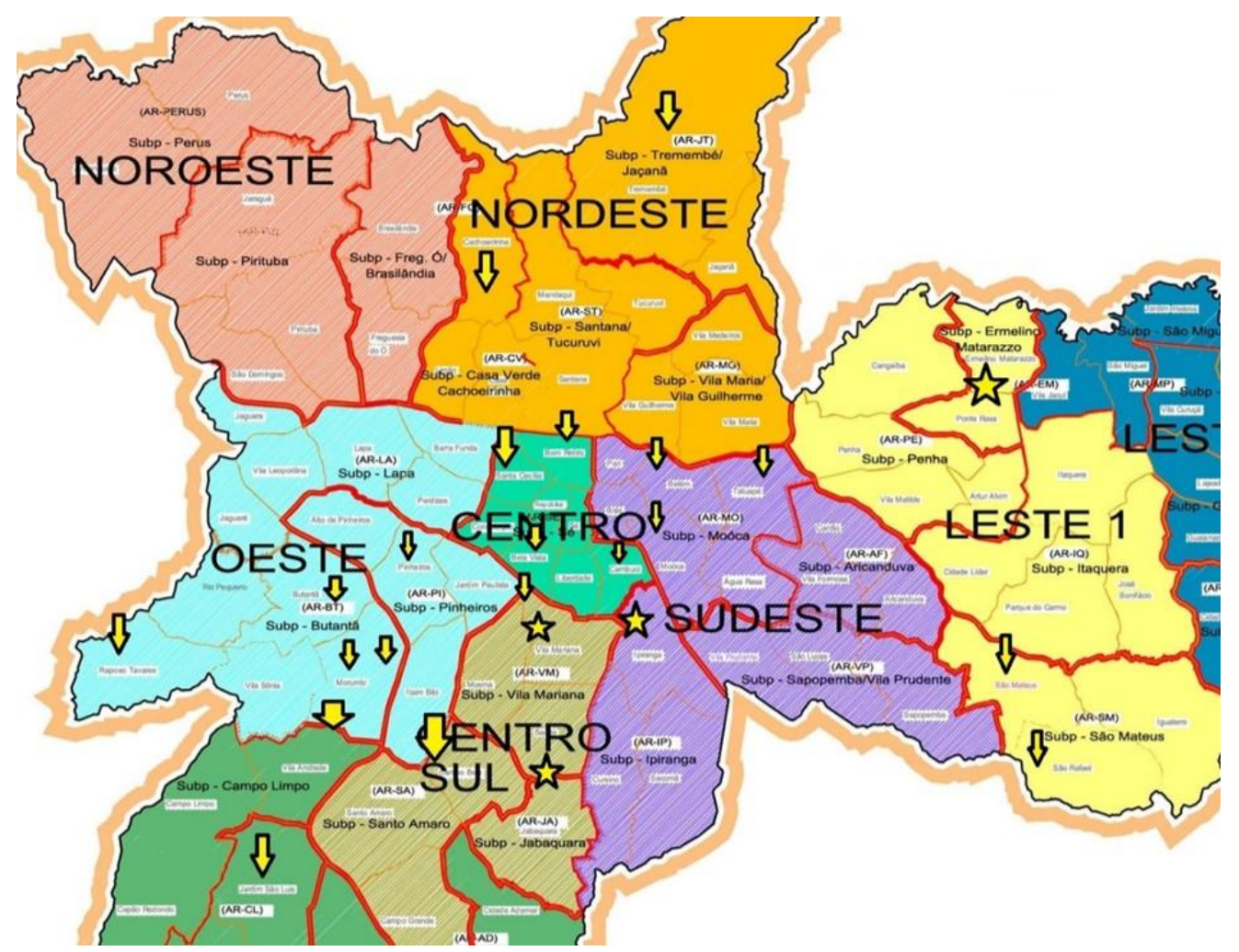

Figura 11 - Elaboração própria baseada nas atividades relacionadas ao Conseg (atas das reuniões e informações do DOM-SP) X reduto eleitoral do vereador/deputado William Woo (ZEs onde obteve maior votação, segundo TSE).

Na mesma direção, presidentes e outros membros de diretoria de Consegs frequentam as sessões da Câmara, especialmente para prestigiar as sessões solenes convocadas pelos vereadores. Entre janeiro de 2003 e março de 2013 - dez anos -, 89 vezes havia ao menos um membro de Conseg presente em sessão solene na Câmara dos vereadores de São Paulo (em muitos casos havia mais de um e diversas vezes chegaram a uma dezena em uma mesma sessão). A presença dos membros de diretoria nessas sessões destinadas a homenagens diversas - desde entrega de prêmios a membros da polícia até a comemoração do dia do softbal ${ }^{81}$-, indica uma tentativa de estreitar relações. Essas relações parecem frutíferas: os vereadores frequentemente lembram na Câmara em seus votos de júbilo ou discursos, os Consegs dos diferentes bairros. Em 2004, foi promulgada a lei № 13.925 estabelecendo o dia municipal dos Consegs.

Não foi possível com os dados saber o quanto essa relação aumenta a possibilidade de avançar as demandas dos Consegs, mas creio que foi suficientemente demonstrado que essa relação entre existe, que existe reciprocidade e que as imagens da sociedade civil como uma esfera

${ }^{81}$ Diário Oficial da Cidade de São Paulo, 23-10-2010, p. 105. 
separada do Estado e em controle do mesmo não são aplicáveis à prática das atividades políticas, no Conseg. Nem é possível dizer que essa proximidade seja prejudicial ao controle do Estado. Nada nos dados estudados indica que a prática contínua da participação tornará a divisão entre atores estatais e atores da sociedade civil mais definida ou mais acentuada como previu Miranda (2009) - o contrário parece ser verdadeiro: quanto maior o tempo, mais as relações de troca comprometerão os envolvidos. Quanto à questão da cooptação - a tese de que a proximidade tem um caráter patrimonialista que diminuiria a atuação contestatória dos atores civis -, será abordada mais adiante, no item 4.4 relativo à questão "e" - a proximidade com o Estado não parece estar necessariamente associada a um comportamento mais cordato dos atores e é preciso saber se há fatores institucionais que influenciam essa desejável, embora sempre relativa, autonomia.

\subsection{Desigualdade e igualdade em direitos e cidadania}

Em 2000 Teresa Caldeira formulou o conceito de democracia disjuntiva para descrever um cetro traço da sociedade brasileira em que os direitos sociais e políticos são razoavelmente legitimados, mas em que os direitos civis ainda enfrentam barreiras. Para Galdeano (2009), as interações nos Consegs pioram a situação dos direitos civis de certos grupos, aprofundando preconceitos de classe e gênero, entre outros, que são reiterados através da fala a partir de um mecanismo semelhante à "fala do crime" (CALDEIRA, 2000).

Se é um fato incontornável que de tempos aparecem nos Consegs manifestações que associam de forma preconceituosa certos grupos ao crime e que pedem políticas duras para lidar com eles, não há nada que demonstre que os Consegs tornem essas representações mais frequentes ou mais "acirradas". Recorrer à literatura e aos relatos das reuniões observadas ajudará a demonstrar que não é esse o caso.

Quanto aos direitos sociais e políticos é possível defender que os Consegs têm ao menos uma características que aponta no sentido oposto ao da segregação: ao proporcionar a oportunidade de interlocução direita com a administração pública em contextos onde moradores tendem a ter menor capital político e social. Para testar a hipótese de que há aspectos em que os Consegs podem ser o oposto da segregação, será comparado o grau de satisfação dos moradores entre distritos com diferentes níveis de renda e escolaridade.

\subsubsection{Os direitos civis}

Galdeano (2009), embora analise em profundidade as disputas internas nos Consegs, não traz evidências de que essas disputas de fato aumentem, ou tornem mais graves as representações 
estigmatizada dos "agentes da insegurança". Não há evidências trazidas pela pesquisa empírica, nem descrição de mecanismos em Galdeano (2009) que demonstrem esse aumento. Por outro lado, as opiniões despóticas ou asiáticas colhidas em 1985 por Soares e Carneiro (1996), às quais aludi, anteriormente eram as mais frequentes - percepções preconceituosas sobre pobres e favelados que deveriam ser tratados com "políticas" tais como migrações forçadas, esterilização em massa, execução sumária etc. Se de tempos em tempos aparecem nos Consegs opiniões que associam pobreza e condição de favela à criminalidade, não se verificou nenhum tipo de prescrição parecida com aquelas verificadas em $1985^{82}$, pelo menos no período pesquisado. Nas reuniões observadas, eventual e isoladamente, os participantes nos Consegs insinuaram que a política de respeito aos direitos humanos atrapalhava o trabalho da polícia, mas isso não permite assumir nem que essa é uma opinião geral e nem que seus portadores necessariamente apoiem medidas tão drásticas como aquelas vistas em 1985, execuções sumárias ou esterilização forçada, por exemplo. Também não foram verificados casos em que o desrespeito aos direitos humanos ensejasse qualquer debate. Ou seja, a "fala do crime", que Caldeira (2000, passim) descreveu para a sociedade paulistana tende a não se propagar nas reuniões. Essa afirmação se baseia na observação das quinze reuniões às quais compareci pessoalmente. Nas reuniões que presenciei, as falas antigarantistas, via de regra, não se tornam conversas, não envolvem mais do que aquele que falou, com uma exceção importante: o tema do rebaixamento da maioridade penal. Esse é um tema que presenciei em duas reuniões. No primeiro caso, em Sapopemba ${ }^{83}$, a fala foi do delegado que fez um discurso defendendo que os participantes usassem a via eleitoral para conseguirem a mudança na constituição que permitissem a imputabilidade penal de menores de 18 anos. O delegado foi aplaudido. Já no Pari ${ }^{84}$, alguns moradores comentando o caso de uma criança supostamente cometera vários roubos, manifestaram-se a favor do rebaixamento, enquanto o capitão e o delegado tentaram relativizar a eficiência do encarceramento de jovens e crianças como solução para os problemas da violência. Ora, a opinião dos participantes dentro dos Consegs parece ser absolutamente coerente com aquela dos moradores fora deles. Levantamento realizado em abril de 2013 pelo instituto de pesquisa Datafolha trouxe como resultado que $93 \%$ dos moradores da cidade de São Paulo eram favoráveis à redução da maioridade penal para 16 anos no Brasil ${ }^{85}$. Ou seja, não há nenhuma evidência de que os Consegs sejam capazes de acirrar questões relacionadas à fala do crime, à estigmatização de moradores favelados, à pena de morte, ao rebaixamento da maioridade penal e assim por diante.

\footnotetext{
82 Infelizmente, opiniões e discursos não são confiavelmente relatados nas atas de reuniões a ponto de permitir uma análise a respeito de temas relativos aos direitos fundamentais.

${ }^{83}$ Reunião Conseg Sapopemba, 28/05/2013, Buffet Kiloko.

${ }^{84}$ Reunião Conseg Pari, 23/05/2013.

${ }^{85}$ http://www1.folha.uol.com.br/cotidiano/2013/04/1263937-93-dos-paulistanos-querem-reducao-damaioridade-penal.shtml
} 
Por fim, o exemplo da reunião do Pari relatado acima, sugere que é possível que os membros natos, no intuito de fazer seguir o regulamento, desestimulem falas contra as garantias fundamentais, tal como prescrito no Artigo 52 que atribui a todos os membros o dever de "Desestimular a apologia à violência, o descumprimento das leis e a violação dos direitos fundamentais da pessoa humana como solução para os problemas de segurança da comunidade".

\subsubsection{Os direitos políticos e sociais}

Não parece banal que quase qualquer morador em qualquer distrito da cidade possa, durante duas horas a cada mês, dividir uma sala com gestores e servidores públicos de órgãos da administração municipal e estadual com oportunidade real e efetiva de fazer uso da palavra para vocalizar demandas, insatisfações, elogios, agradecimentos, informes, suas teorias sobre o crime e assim por diante. Para as classes altas e muito altas, a proximidade com os circuitos da política e da administração pública é muito maior de modo que é razoável supor que essa oportunidade de estar cara-a-cara com os gestores seja menos importante. Além da proximidade, as classes altas e muito altas dispõem, em geral, de um maior conjunto de habilidades, melhor conhecimento de instrumentos próprios para reivindicações de direitos e disputas, especialmente a via jurídica. Nesse sentido, parece ser a característica de alguns Consegs o recurso ao judiciário. Em reunião observada no Conseg Perdizes/Pacaembu ${ }^{86}$ a orientação imediata do presidente e sua esposa (esta, expresidente do Conseg Lapa) a um casal com problemas de som alto na vizinhança foi recorrer ao Ministério Público, o que seria feito através do Conseg. Esse é um dado consistente com análise de outra fonte de informação. Na pesquisa do Diário Oficial do Estado de São Paulo foram encontrados 29 casos de recurso ao Ministério Público (inquéritos civis e/ou peça de informação) e mais 3 casos que chegaram a audiências no judiciário envolvendo Consegs. Desses, foram considerados apenas casos em que o Conseg ou um de seus membros (representado como membro do Conseg) era a parte iniciadora da ação (30 casos). Os casos referiam-se a ações contra órgãos da administração pública ou contra outros membros em contexto de disputa eleitoral e foram mais frequentes entre os estratos mais ricos, como mostra a tabela 4 .

\footnotetext{
${ }^{86}$ Reunião Conseg Perdizes/Pacaembu, sede da SABESP, 18/06/2013.
} 
Tabela 4 - Casos no judiciário/MP envolvendo

Consegs e total por estrato

\begin{tabular}{|c|c|c|c|}
\hline CONSEG & Número de casos & Estrato & $\begin{array}{l}\text { Total de ações } \\
\text { por estrato }\end{array}$ \\
\hline Perdizes & 10 casos & 4 & \multirow[t]{6}{*}{19} \\
\hline Morumbi & 04 casos & 4 & \\
\hline Paraíso & 02 casos & 4 & \\
\hline Santa Cecília & 01 caso & 4 & \\
\hline Itaim Bibi & 01 caso & 4 & \\
\hline Parque São Jorge & 01 caso & 4 & \\
\hline Cidade Ademar & 02 casos & 3 & \multirow[t]{3}{*}{$05^{*}$} \\
\hline Mooca & 01 caso & 3 & \\
\hline Centro & 01 caso & 3 & \\
\hline Jardim São Luiz & 03 casos & 2 & \multirow[t]{3}{*}{$07 *$} \\
\hline Penha & 02 casos & 2 & \\
\hline Bom Retiro & 01 caso & 2 & \\
\hline $\begin{array}{l}\text { Vila Maria e Parque } \\
\text { Bristol (representação } \\
\text { conjunta) }\end{array}$ & 01 caso & 2 e 3 & NSA \\
\hline Não informado & 01 caso & NSA & NSA \\
\hline
\end{tabular}

Elaboração própria a partir dos dados do Diário Oficial do Estado de São Paulo, 2003 - 2013.

*Foi incluído na somatória o caso de representação conjunta de Vila Maria e Parque Bristol)

Além de demonstrar que os Consegs têm estratégias mais amplas de fazer avançar demandas do que o momento da reunião e as relações com os gestores e servidores participantes, a tabela 4 traz uma informação importante para o ponto em questão. Os Consegs dos distritos mais abastados (estrato $4^{87}$ ) recorrem mais à via judiciária. Não apenas o número total de casos é maior (19) como também o número de Consegs que o fizeram pelo menos uma vez nos últimos dez anos (seis) é maior no estrato 4 e corresponde à soma para os casos dos estratos 03 e 02 . Não há diferença significativa entre os estratos 03 e 02 , mas o estrato 01 , que corresponde aos distritos com menor porcentagem de moradores abastados, nem sequer apareceu na pesquisa. $O$ intuito da apresentação desses dados é demonstrar que de fato há uma diferença nas estratégias de avanço de demandas fora do momento da reunião entre os diferentes Consegs. No caso do poder judiciário, este está completamente fora do contexto do Conseg de modo que aqueles que usam esse recurso já dominam a linguagem e estratégias específicas antes e além das relações nesse espaço participativo. Isso é uma evidência a corroborar a hipótese de que o Conseg é menos importante

\footnotetext{
${ }^{87}$ Lembrando que o estrato 4 é o que tem maior porcentagem de responsáveis por domicílios que ganham mais de $20 \mathrm{SMs}$. 0 estrato 1 é o que tem menor porcentagem.
} 
para os mais abastado, não traz avanços tão grandes em relação àqueles recursos de que esses atores já dispõem.

Outra forma de analisar a questão da situação dos direitos sociais e políticos entre os Consegs com diferentes contextos sociais é comparar o grau de satisfação entre eles. Para isso foi criada a variável satisfação que indica a chance de aparecer um agradecimento/elogio em comparação com a chance de aparecer uma reclamação nas falas dos moradores. A tabela 5 mostra o resultado da regressão logística para cada variável testada isoladamente.

Tabela 5 - Razão de chance de ocorrência de agradecimento (satisfação) para diferentes variáveis independentes usando a técnica de regressão logística

\begin{tabular}{|l|l|l|l|}
\hline Variável & Razão de chance & $\mathrm{P}>|\mathrm{z}|$ & Prob > chi2 \\
\hline \% pobres & 1.055 & 0.024 & 0.020 \\
\hline \% ricos & .907 & 0.046 & 0.033 \\
\hline \% analfabetos & 1.149 & 0.367 & 0.367 \\
\hline Taxa de roubos & 1.000 & 0.275 & 0.295 \\
\hline Taxa de furtos & 1.000 & 0.594 & 0.601 \\
\hline Taxa atual de homicídios & 1.011 & 0.247 & 0.259 \\
\hline Taxa histórica de homicídios & 1.000 & 0.755 & 0.755 \\
\hline Presença de representante & 1.068 & 0.707 & 0.707 \\
\hline Taxa de participação & .998 & 0.671 & 0.668 \\
\hline
\end{tabular}

Os resultados da coluna $\mathrm{P}>|\mathrm{z}|$ indicam que apenas as variáveis relacionadas a percentual de pobres e percentual de ricos mostraram-se significativas (menor que 0,5 ). No resultado em razão de chances, um número igual a 1 indica que não há associação entre duas variáveis, um número menor que 1 , que existe associação e é negativa, enquanto um número maior que 1 indica que há uma associação positiva entre as duas variáveis. Nesse caso, um aumento de $1 \%$ na presença de pobres no distrito, aumenta em 5\% a razão de chances de ocorrer um agradecimento em relação a uma reclamação. E o aumento de $1 \%$ na presença de ricos no distrito, diminui em quase $10 \%$ a chance de 
ocorrer um agradecimento. Parando a análise nesse ponto seria possível apontar que os Consegs tendem a funcionar no sentido de reduzir disparidades de renda no acesso a direitos. Mas ainda não é possível afirmar que as variáveis de renda são de fato importantes, pois é preciso controlar pelos efeitos de outras variáveis. Dessa forma, foram rodados vários modelos com diferentes combinações das variáveis disponíveis (renda, escolaridade, crimes, presença de representante do legislativo e taxa de participação). O melhor modelo testado (com o melhor fit) ${ }^{88}$ inclui as variáveis de porcentagem de analfabetos e porcentagem de pobres no distrito, conforme tabela 6 .

Segundo o modelo (tabela 6), o aumento de $1 \%$ no percentual de pobres no distrito aumenta em $16 \%$ a razão de chance de ocorrer agradecimento no respectivo Conseg. No sentido contrário o aumento de $1 \%$ no número de analfabetos no distrito diminui em $51 \%$ a razão de chance de ocorrer um agradecimento ${ }^{89}$. Ou seja, os resultados são evidências de que o Conseg é capaz de diminui disparidades de renda no acesso a bens públicos, mas por outro lado, reproduz as disparidades de educação no acesso a esses bens. Uma interpretação possível é que a existência dos Consegs abre canais de comunicação onde eles são mais escassos, nos distritos mais pobres, mas não é suficiente para criar pontes que superem especificamente os desafios da baixa escolaridade.

Tabela 6 - Regressão logística da a taxa de satisfação

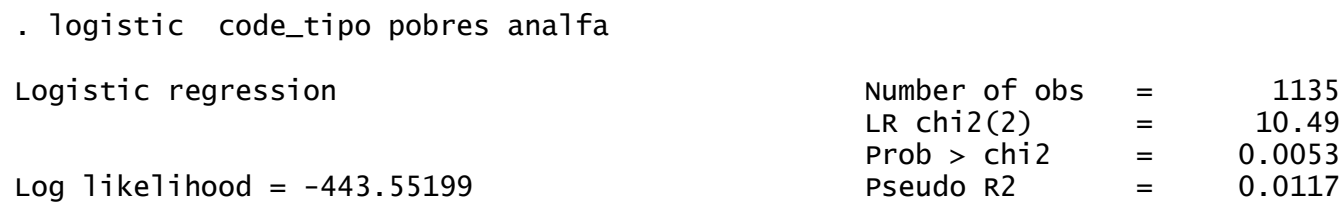

\begin{tabular}{r|rccccr}
\hline code_tipo & odds Ratio & Std. Err. & $\mathrm{z}$ & $\mathrm{P}>|\mathrm{z}|$ & & [95\% Conf. Interval] \\
\hline pobres & 1.160272 & .0564187 & 3.06 & 0.002 & 1.054799 & 1.276291 \\
analfa & .487005 & .1554531 & -2.25 & 0.024 & .2605122 & .9104138 \\
_cons & .0559962 & .0202406 & -7.97 & 0.000 & .0275728 & .1137202 \\
\hline
\end{tabular}

(ocorrência de agradecimento) com os preditores: \%pobres e \%analfabetos

Análise realizada no software Stata. Variável "pobres" mede a porcentagem de RpD com renda < 2 SMs; variável "analfa" mede a porcentagem analfabetos no distrito.

\footnotetext{
${ }^{88}$ Para ver todos os modelos testados, consultar tabela B.1 no apêndice B.

${ }^{89}$ Foi realizada análise de correlação entre os resíduos para as duas variáveis que se mostraram efetivas. Para a variável \%pobres, a correlação é de -0.0236 e para a variável \%analfabetos a correlação é de -0.0433 de modo que o modelo se mantém aceitável do ponto de vista das técnicas estatísticas.
} 
Neste item 4.2 foram discutidas três questões que apontam para as seguintes conclusões: a) os Consegs não acirram representações sobre violência e criminalidade que deslegitimem os direitos civis e promovem segregação; b) os Consegs são capazes de diminuir disparidades no acesso a direitos entre as faixas de renda mais altas e mais baixas; c) os Consegs não são suficientes para superar desafios relacionados à baixa escolaridade no avanço de demandas. Esses desafios podem estar relacionados diretamente a menor participação nos contextos de alta porcentagem de analfabetos, mas isso será demonstrado no item 4.3.

Analisando sob o prisma da democracia disjuntiva, como formulado por Caldeira (2000) parece que há nos Consegs, como no restante da sociedade, uma legitimação dos direitos sociais e políticos pois o canal está aberto em todas as áreas da cidade e a satisfação é maior entre os moradores dos distritos mais pobres. Quanto à dificuldade relacionada à baixa escolaridade, ela não parece ser fruto da falta de consenso a respeito deste direito social especificamente, mas do desafio próprio desta área de política. Já os direitos civis, ainda que não sejam legitimados, não são deslegitimados nos Consegs, isso porque a "fala do crime" (ibidem, passim) não se propaga no Conseg da mesma forma que se propaga fora dele.

\subsection{O desejo difuso de lei e ordem como preditor da participação}

A partir de uma certa leitura dos autores da sociologia da punição Moraes (2011) concluiu que as demandas relacionadas a infraestrutura e desordem que aparecem nos Consegs são parte de uma sensação generalizada de insegurança nas grandes cidades. Como já dito no capítulo um, essas interpretações precisam ser vistas com cautela ao serem aplicadas ao caso brasileiro. Esse entendimento pode ser testado verificando-se os preditores da participação, ou, em outras palavras, por que as pessoas frequentam os Consegs. Como a participação tende aumentar junto com o aumento de renda e escolaridade, se Moraes estiver correta, esses fatores devem explicar sozinhos a participação. A hipótese desse trabalho é diferente: variáveis de ocorrência de crimes devem ajudar a explicar a participação.

A melhor forma para testar a hipótese de que a ocorrência de crimes está associada à participação nos Consegs seria usar dados de pesquisa de opinião, uma pesquisa de tipo survey para medir a experiência de vitimização - direta ou indireta - junto àqueles que efetivamente participam dos Consegs, bem como aferir o perfil de renda e escolaridade dos mesmos. Infelizmente não foi possível conseguir essas informações considerando-se as limitações de tempo e recursos da pesquisa. Por outro lado, é possível usar as taxas de crime no distrito em substituição às informações 
dos indivíduos nesse caso específico. Isso porque o mais importante para testar a hipótese de que há uma preocupação específica com a criminalidade que move as pessoas ao Conseg, não é o fato de elas terem ou não sido vítimas diretas de um crime, mas a chance percebida de sê-lo e isso pode ser medido pelas taxas de criminalidade no distrito. Assumir isso não é o mesmo que afirmar que os cidadãos paulistanos consultam as taxas de criminalidade no jornal ou no site da Secretaria de Segurança Pública a cada três meses, quando são publicadas oficialmente e aí resolvem ou não tomar parte nas reuniões. Mas sim que as experiências próximas - de vizinhos, familiares, professores, alunos etc. -, além da experiência própria, informam a percepção do perigo, especialmente em crimes razoavelmente comuns como roubo e furto. Quanto às taxas de renda e escolaridade, estão sendo utilizadas as informações do distrito e não as informações individuais, nada mais é do que a opção subótima e os resultados precisam ser observados com cautela. Foram realizadas analises de regressão com todas as variáveis e escolhido o melhor modelo possível (com o maior poder explicativo $)^{90}$.

Tabela 7 - Regressão OLS. Variável dependente taxa de participação e preditores: \%pobres, taxa de furtos, e \% de analfabetos

\begin{tabular}{|c|c|c|c|c|c|}
\hline Source & SS & $d f$ & MS & Number of obs $=$ & 99 \\
\hline Mode 1 & 25.4232019 & 3 & 8.47440064 & Prob $>F$ & 0.0000 \\
\hline Residual & 30.6841356 & 95 & .322990901 & R-squared & 0.4531 \\
\hline Tota1 & 56.1073375 & 98 & .572523852 & Root MSE & .56832 \\
\hline
\end{tabular}

\begin{tabular}{r|rrrrrr}
\hline logtxquorum & Coef. & Std. Err. & $\mathrm{t}$ & $\mathrm{P}>|\mathrm{t}|$ & [95\% Conf. Interva1] \\
\hline logpobres & .7577562 & .355312 & 2.13 & 0.036 & .0523726 & 1.46314 \\
logfrutos & .4451861 & .080029 & 5.56 & 0.000 & .2863085 & .6040637 \\
loganalfa & -.5780363 & .2135377 & -2.71 & 0.008 & -1.001962 & -.1541104 \\
_cons & -1.564498 & 1.060985 & -1.47 & 0.144 & -3.670821 & .5418242 \\
\hline
\end{tabular}

Análise realizada no software Stata. Variável "pobres" mede a porcentagem de RpD com renda $<2$ SMs; variável furtos mede a taxa de furtos/ 100 mil habitantes, variável "analfa" mede a porcentagem analfabetos no distrito ${ }^{91}$.

Os dados da tabela 7 indicam que há associação positiva entre taxa de participação e as variáveis \%pobres e taxa de furtos, e uma associação negativa entre taxa de participação e \%analfabetos. Há dois pontos importantes nesse modelo $^{92}$. O primeiro está relacionado com a

\footnotetext{
${ }_{90}$ Para visualizar a tabela comparativa dos modelos, consultar tabela B.2 no apêndice B.

${ }^{91}$ As variáveis foram transformadas em logaritmos porque não apresentavam distribuição normal, violando os pressupostos do modelo o que distorceria os dados finais.

${ }^{92} \mathrm{Na}$ regressão de tipo OLS, os coeficientes são interpretados em números negativos e positivos. O número zero representa não associação entre as variáveis, um número positivo indica associação positiva (o aumento
} 
questão do item 4.2: a participação aumenta com o aumento da porcentagem de pobres e diminui com a maior porcentagem de analfabetos no distrito. Ou seja, a participação se comporta de forma parecida com a satisfação, reforçando as conclusões do item 4.2. A baixa participação nos distritos com maior porcentagem de analfabetos pode causar um menor índice de satisfação. No que diz respeito a questão deste item especificamente, encontramos uma associação positiva entre participação e ocorrência de furtos no distrito. A influência das três variáveis não é radicalmente diferente em termos de magnitude e o modelo é capaz de explicar $45 \%$ da variação o que é um número razoável.

Para esta questão, a análise é mais direta - levando-se em consideração os dados da amostra, a participação nos Consegs aumenta com a ocorrência do crime de furto e aumenta significativamente. Ou seja, as pessoas não frequentam o Conseg apenas em função de uma insegurança generalizada nas grandes cidades, relacionada à desordem no espaço público, mas também em função de uma insegurança específica relacionada à ocorrência de crimes. Esses resultados são, todavia preliminares e precisam de pesquisas suplementares, especialmente para conhecer o perfil de vitimização, renda e escolaridade daqueles que efetivamente frequentam esses espaços participativos.

\subsection{A inversão da autoridade ou, as possibilidades de ação autônoma dos atores societais}

Diferentemente do que observou Moraes (2011), a contestação da autoridade policial em São Paulo não se dá em termos de inversão da autoridade e é muito diferente da contestação dirigida a outros representantes do Estado. Como foi demonstrado no item 4.1, os participantes do Conseg, especialmente a diretoria, interagem com representantes do legislativo na formação de capital político, em outras palavras, em um movimento de trocas interessadas. Nesse item pretendo demonstrar que: i) essa relação de proximidade entre Conseg e o circuito da política formal não impede que os atores adotem posturas de confronto em relação aos representantes do Estado, até mesmo "com o dedo em riste" e; ii) que os participantes se dirigem às autoridades policiais de forma mais contida, resignada, cautelosa e titubeante em comparação com suas atitudes perante os representantes das instituições não policiais. Demonstrada que a postura contenciosa existe mas que em relação às policiais ela se manifesta de maneira diferente, pretendo propor uma explicação de também de ordem institucional, no sentido de que instituições importam, o que será feito no capítulo 5.

da variável independente é acompanhado pelo aumento na variável dependente) e um número negativo indica associação inversa. 


\subsubsection{Contestação $\mathrm{x}$ confronto: como os moradores expressam perante os diferentes representantes do Estado}

Tanto órgãos de segurança pública quanto aqueles que lidam com a infraestrutura urbana são muito demandados nos Consegs. A diferença está em como as diferentes instituições são demandadas. As reclamações ou solicitações dirigidas à subprefeitura, CET e SPTrans etc. podem ser neutras, amigáveis ou agressivas e acusatórias, raramente, até desrespeitosa, mas as falas dirigidas às polícias não são de confronto direto. A partir de uma análise quantitativa das falas dos participantes endereçadas aos órgãos públicos nos Consegs, apenas das reuniões observadas diretamente, tentarei demonstrar a diferença que existe quando a instituição demandada é policial.

Levando-se em conta os dados da tabela a seguir, fica claro que o enfrentamento não é a regra por excelência da participação nos Consegs. Demandas neutras, elogios e justificativas (ou seja, não contenciosas) somam juntos $76 \%$ das falas dirigidas às polícias e $74 \%$ daquelas dirigidas a outros órgãos. Mesmo assim esses dados têm muito a dizer sobre posturas de enfrentamento em relação ao Estado.

Tabela 8 - Como os participantes se dirigem às autoridades

\begin{tabular}{|l|c|c|l|l|}
\hline $\begin{array}{l}\text { FALAS DOS PARTICIPANTES NAS REUNIÕES SOBRE OS, } \\
\text { OU DIRIGIDAS AOS, REPRESENTANTES DOS ÓRGÃOS } \\
\text { PÚBLICOS }\end{array}$ & POLÍCIAS & $\%$ & $\begin{array}{l}\text { OUTRAS } \\
\text { INSTITUIÇÕES }\end{array}$ & $\%$ \\
\hline $\begin{array}{l}\text { Demanda neutra: demanda ou reclamação SEM conteúdo } \\
\text { ou tom de contestação. }\end{array}$ & 44 & $40,3 \%$ & 55 & $57,0 \%$ \\
\hline $\begin{array}{l}\text { Elogio: elogio, agradecimento ou reconhecimento quando } \\
\text { uma demanda foi atendida. }{ }^{94}\end{array}$ & 24 & $22,0 \%$ & 13 & $13,5 \%$ \\
\hline
\end{tabular}

93 É possível argumentar que as categorias utilizadas misturam indistintamente forma e conteúdo. Na realidade, todas as categorias implicam forma e conteúdo, de modo que são mutuamente excludentes e exaustivas, permitindo a análise proposta.

${ }^{94}$ Elogios são amigáveis por definição, incluem forma e conteúdo. 


\begin{tabular}{|c|c|c|c|c|}
\hline $\begin{array}{l}\text { Reclamação moderadamente contenciosa: em um tom } \\
\text { agressivo ou irônico leve, acusação gravidade pequena ou } \\
\text { indireta, contradito em relação à fala da autoridade. }\end{array}$ & 26 & $23,8 \%$ & 17 & $17,7 \%$ \\
\hline $\begin{array}{l}\text { Justificativa: problemas não resolvidos pelos } \\
\text { gestores/servidores são causados por fatores externos } \\
\text { (comportamento das vítimas, direitos humanos, poder } \\
\text { político, a má conduta de indivíduos isolados, falta de } \\
\text { condições de trabalho, o comportamento incivil da } \\
\text { população, condições socioeconômicas) ou são causados } \\
\text { por uma decisão racional, bem fundamentada dos atores } \\
\text { estatais, ainda que a decisão seja contrária ao desejo dos } \\
\text { participantes do Conseg. }\end{array}$ & 15 & $13,76 \%$ & 04 & $4,1 \%$ \\
\hline $\begin{array}{l}\text { Reclamação ou denúncia em confronto aberto: } \\
\text { fortemente agressiva, bate-boca }{ }^{96} \text { ou acusação grave e } \\
\text { direta. }\end{array}$ & ZERO & ZERO & 04 & $4,1 \%$ \\
\hline $\begin{array}{l}\text { Conquista da comunidade: são casos em que a atuação } \\
\text { do gestor/servidor é omitida quando se anuncia uma } \\
\text { demanda atendida. Por deixarem de reconhecer o } \\
\text { trabalho do gestor ali presente, têm um conteúdo } \\
\text { implicitamente contestatório. }\end{array}$ & ZERO & ZERO & 03 & $3,1 \%$ \\
\hline SOMA & 109 & $100 \%$ & 96 & $100 \%$ \\
\hline
\end{tabular}

Os números encontrados na terceira linha da tabela parecem sugerir, à primeira vista, um grau maior de satisfação dos moradores em relação às instituições policiais uma vez que a porcentagem de falas de elogio é maior para essas. Curiosamente porém, as reclamações moderadamente contenciosas representam $23,8 \%$ das falas em direção às policias, enquanto entre os órgãos não policiais, essa porcentagem é de $17,7 \%$, deixando as polícias com uma desvantagem de $6 \%$. Já as falas de confronto aberto simplesmente não apareceram para as policias e somaram quatro casos, ou $4,1 \%$ das falas em direção aos atores não policiais. Considerando-se os dados das

\footnotetext{
${ }_{95}$ Aplica-se a mesma lógica de forma e conteúdo utilizada em elogio.

${ }^{96}$ Uso a expressão bate-boca para destacar que essas são discussões em que, além de haver réplica, tréplica e assim por diante, há um caráter mais agressivo em oposição a discussões que podem até serem longas, mas que são mais amigáveis.

${ }^{97}$ Forma e conteúdo mais uma vez são indistinguíveis.
} 
categorias reclamações moderadamente contenciosas e confronto aberto, é possível aventar que o desejo - ou estratégia - de confronto que eventualmente aparece entre os cidadãos só chega a se manifestar claramente em relação a um tipo de ator estatal, mas em relação a outro ela permanece latente.

Nos Consegs não é raro que moradores se levantem em defesa de uma autoridade, tentando justificar questões que percebem como um problema. Foram enquadradas nessa categoria alegações de que problemas não resolvidos têm causas externas (injustiça social, comportamento das vítimas, direitos humanos, poder político, falta de condições de trabalho, má conduta indivíduos isolados) ou ainda, quando um gestor/servidor decide contrariamente ao que foi demandado pelo Conseg, o participante defende a decisão como sendo técnica, ou bem fundamentada. Os exemplos a seguir ilustram essas situações que foram classificadas como justificativas.

Homem na plateia se apresenta, diz que é presidente de um determinado sindicato, que trabalha ali perto. Pergunta "por que os acampados estão lá?" [moradores de rua que estariam abrigados em barracas durante o inverno em uma praça das imediações] Afirma que os "acampados" usam drogas "na cara de todo mundo. A viatura está lá pra salvaguardar?" Então pergunta ao capitão se haveria determinação expressa para ninguém "mexer com eles". Pergunta a mesma coisa para o comandante da GCM. (Reunião Conseg Liberdade, 21/08/2013).

Moradora que foi à reunião pra reclamar do pancadão reconhece que o conselho tutelar esteve presente, mas que havia tanta gente que o trabalho teria se tornado impraticável. (Reunião Capão Redondo, 24/09/2013)

Presidente mostra ofício da coordenadoria dos Consegs sobre construção de base comunitária da PM na praça Rotary Clube. Diz que tinha uma base móvel ali anteriormente, que desde o início deu problemas porque não tinha luz. Ele [presidente] conseguiu ligação na banca de jornal e se propôs a pagar a conta de luz ele mesmo. Que os PMs usavam o banheiro da biblioteca e que com o tempo a biblioteca não gostou. Que as condições dos policiais eram tão ruins que por isso haviam tirado a base. Que havia terreno, que a prefeitura até havia autorizado, mas a Secretaria Municipal do Verde e Meio Ambiente não autorizara. Que a Secretaria do Verde e Meio Ambiente mandava mais que a Presidente. Lê ofício da Coordenadoria que justificava por que a base fixa não é desejável, que melhor é ter viatura e base móvel, para circular melhor, que os policiais não podem sair da base. (Reunião Mandaqui, 19/08/2013)

Em $13,76 \%$ das vezes que falaram sobre as polícias, os moradores o fizeram para justificar um problema percebido ou uma atuação insuficiente, o que só aconteceu em $4 \%$ das falas em relação às outras instituições. Em outras palavras, os moradores sentem necessidade de defender as instituições policiais, o que quase não aparece para os outros órgãos públicos. Um exemplo extremo, 
embora não totalmente isolado, é o da reunião do Mandaqui, citado acima: mesmo com o ofício da Coordenadoria dizendo que o comando achou por bem não usar a base fixa, o presidente dirige sua desaprovação para a Secretaria do Verde e Meio Ambiente que, do alto de seu poder, afinal "manda mais que a presidente", teria tido uma atitude arbitrária e contrariado o desejo da comunidade.

Outro par de categorias que podem se mostrar reveladoras ao serem analisadas em conjunto, são elogios e conquista da comunidade. 24 vezes (22\%) os cidadãos fizeram elogios, agradeceram e/ou reconheceram uma ação por parte de uma das polícias e não apareceu nenhum caso em que uma demanda atendida nas áreas da alçada das polícias fosse atribuída exclusivamente ao empenho do Conseg e seus participantes. Já quando se trata de conquistas relacionadas a atribuições de outros órgãos públicos, por três vezes moradores se congratularam por terem conquistado algo junto ao poder público sem mencionar as instituições ou indivíduos que executaram a tarefa. À luz dessa indiferença, a diferença na porcentagem de falas elogiosas entre instituições policiais e não policiais parece diminuir de importância. Em outras palavras, parece haver uma deferência maior em relação às polícias, uma necessidade maior de demonstrar reconhecimento, apreço.

Cada uma dessas análises parecem não apontar diferenças tão importantes entre o tratamento em relação às polícias e aquele dispensado a representantes de outros órgãos públicos. É o conjunto de resultados acumulados que dá peso ao argumento:

$>$ Os participantes nunca se dirigem aos policiais em confronto aberto, mas o fazem com os outros representantes.

$>$ Os participantes justificam ações indesejadas ou insuficientes das polícias muito mais do que justificam as ações dos representantes civis.

$>$ Os participantes nunca deixam de reconhecer o papel do Estado quando uma demanda é atendida na área de segurança, mas às vezes ignoram a intervenção de gestores dos outros órgãos

$>$ Reclamações moderadamente contenciosas aparecem em número ligeiramente maior para as polícias o que pode ser um indício de que existe potencial para conflito aberto, mas esse potencial não se materializa.

Tomadas em conjunto, essas pequenas análises parece corroborar de forma consistente a hipótese de que existe uma diferença considerável na atitude dos participantes quando dirigem suas manifestações para as instituições policiais e para instituições não policiais. Uma das reuniões observadas, por conter um grande número de exemplo das categorias mencionadas, serve bastante bem para dar substância e sentido ao argumento de que há algo de especial nessa relação. 
Das quinze reuniões observadas para esta pesquisa, apenas uma vez foi notada uma postura questionadora um pouco mais sustentada em relação à polícia por parte de moradores - no caso, por parte de dois moradores. O exemplo dessa reunião é emblemático porque mostra sucessivos avanços e recuos na responsabilização da polícia em questões dirigidas aos representantes das agências de aplicação da lei. A atitude dos dois moradores em um primeiro momento parece simples falta de coerência. Uma reflexão um pouco mais cuidadosa porém, descortina a consciência dos atores enquanto se movimentam em um terreno que parecem perceber como sendo minado. É uma narração um tanto quanto longa, mas por considera-la bastante reveladora, incluo abaixo. Não é uma narração da reunião toda, mas apenas da movimentação discursiva em torno de um determinado eixo analítico: a postura em relação à polícia em contraste com a subprefeitura e outros órgãos não policiais.

Em uma reunião no Conseg do Capão Redondo ${ }^{98}$, em 2013, os moradores Ademar e Lucia ${ }^{99}$ foram bastante eloquentes e juntos ocuparam boa parte do tempo da reunião, falando sobre variados assuntos, tanto sobre a polícia quanto sobre os órgãos da administração municipal. Em uma de suas primeiras falas, Ademar pergunta em tom acusatório "Cadê a subprefeitura?". Naquele momento, estava presente o representante da subprefeitura de $\mathrm{M}^{\prime}$ Boi Mirim, mas a representante da subprefeitura do Campo Limpo ainda não havia chegado ${ }^{100}$. De forma semelhante, estava presente um capitão da polícia militar, mas o delegado só chegaria alguns minutos depois e mesmo assim Ademar só se manifestou sobre a ausência do representante da administração municipal, ao mesmo tempo ignorando e sutilmente fazendo notar, a ausência do representante da polícia civil. Alguns minutos depois, com uma estratégia de avanços e recuos, Ademar se torna um dos protagonistas de uma participação questionadora em direção às polícias, a mais sustentada que observei em todos as reuniões estudadas. Mesmo assim, o confronto direto não se materializou.

Primeiro Ademar questiona que desde o plebiscito (sic) do desarmamento a circulação de armas teria aumentado ${ }^{101}$ e trazia consigo como evidência, um exemplar do jornal Folha de São Paulo com uma matéria sobre o assunto publicada alguns dias antes. $O$ morador questionava como aquilo poderia ser possível se o Estatuto do Desarmamento havia tornado mais restritivo o comércio

\footnotetext{
${ }^{98}$ Reunião observada: Capão Redondo, 30/07/2013, sede da Associação Assistencial e Promocional do Capão Redondo.

${ }^{99}$ Nomes fictícios.

100 Como mencionado anteriormente, a divisão administrativa municipal não é a mesma dos distritos policiais/Consegs. Quando a área de algum Consegs encontra-se dividida entre a área de duas subprefeituras, é necessário que cada uma envie um representante.

${ }^{101}$ Houve no Brasil um referendo sobre a proibição da comercialização de armas de fogo e munições, ocorrido em 23 de outubro de 2005. O referendo era sobre um artigo específico do Estatuto do Desarmamento que visava a tornar a proibição de comercialização de armas de fogo uma regra, enquanto a permissão, tonar-se-ia exceção. O próprio estatuto previa o referendo, mas o artigo 35 não foi aprovado.
} 
de $\operatorname{armas}^{102}$. O delegado responde sem se exaltar ou demonstrar irritação que seriam armas clandestinas, ilegais, que mesmo sendo complicado comprar armas, a polícia apreenderia 2 ou 3 por dia. Ademar diz então que "o sujeito para entrar na polícia deveria ser investigado" e cita um caso da cidade de Diadema no interior do estado de São Paulo onde um policial teria cometido um crime noticiado alguns dias antes. Dessa vez quem responde é o Capitão que, embora demonstre desconforto, também não se exalta e sensatamente racionaliza que mesmo havendo exame psicológico para ingressar na carreira da polícia militar, não era possível prever tudo o que um indivíduo iria fazer no futuro. Logo em seguida Lucia se envolve: relata que na área de um determinado bairro local estariam acontecendo assaltos com moto, mas que as pessoas daquela região estariam esquecendo de registrar boletim de ocorrência e que esse fato a estava preocupando porque esses crimes não seriam registrados nas estatísticas e, consequentemente, não seriam levados em conta no planejamento das rondas e que também estariam acontecendo roubo aos carteiros e cita o nome das ruas das ocorrências. Com as meias palavras "Se não tem B.O...", o delegado dá a entender que nada poderia fazer se as ocorrências não fossem devidamente registradas na delegacia. Dessa vez uma terceira pessoa intervém: "as pessoas dizem que não fazem BO porque sabem que nada vai acontecer". Depois que o delegado tenta se defender com um discurso de impotência - que atende em 3 DPs, que a PM faz 3 flagrantes durante a noite, que não haveria tempo de fazer BO à noite, que seria melhor que as pessoas que pudessem esperar fossem de dia - e de responsabilização das vítimas - "as pessoas têm tempo pra fazer tanta coisa inútil, porque não têm tempo de ir à delegacia fazer BO?". Curiosamente Ademar sai em defesa da polícia alegando que uma pessoa de suas relações teria sofrido ameaça, que foi à delegacia e que teria sido muito bem atendida. Na sequência a conversa torna-se dispersa, mas ainda focada no tema da segurança e Ademar aproveita para dar sua opinião de que as pessoas em geral são displicentes e não sabem prevenir ocorrências, reproduzindo mais uma teoria de responsabilização da vítima muito recorrente na fala dos policiais nas reuniões observadas. Conforme a reunião vai avançando, Ademar redireciona sua artilharia e aumenta o poder de fogo - começa a fazer intervenções cada vez mais exaltadas, aumentando o tom de voz para cobrar e criticar outros serviços públicos: diz que é conselheiro de saúde e que agentes comunitários de saúde, que deveriam avisar as datas da operação cata-bagulho, não fazem nada, que batem o cartão e vão pra casa ver $\mathrm{TV}^{103}$; faz referência

\footnotetext{
${ }^{102}$ Ainda que o artigo 35 não tenha sido aprovado, o Estatuto do Desarmamento logo entrou em vigor e mesmo sem esse artigo aumentava a restrição ao porte de armas.

${ }^{103}$ A representante da subprefeitura do Campo Limpo esclarece que há uma parceria com a área da saúde para que os agentes comunitários, cujo trabalho inclui a circular no bairro, avisem das datas da operação catabagulho para a população. Operação cata-bagulho é um tipo de ação da administração municipal que periodicamente recolhe materiais descartados de grande volume que não podem ser recolhidos pela coleta de lixo diária.
} 
a três endereços para os quais teria solicitado apara de grama e mato e por fim indigna-se que sobre a reclamação de entulho em determinada rua, a subprefeitura teria multado injustamente o morador da casa mais próxima em vez de providenciar a retirada do lixo. No ponto máximo de sua exaltação - espontânea ou calculada -, Ademar questiona a própria utilidade da reunião já que nada seria feito para em seguida ponderar que "a PM e a delegacia cumprem, mas a subprefeitura não". Em outro momento, recupera o tom indignado para reclamar que já haviam se passado 7 meses de governo $^{104}$ e que nada havia sido feito. Mais adiante, nova intervenção de Ademar, perguntando quantas viaturas haveriam na 3a Companhia (da PM) e quando o capitão responde que haviam aproximadamente 15 viaturas e que haviam juntado a 4 a e 5a Cias deixando uma área excessivamente grande para o policiamento, Ademar faz coro à reclamação do oficial responsabilizando o poder político: "porque estamos na periferia os caras acham que é terra de ninguém". Alguns outros assuntos de infraestrutura foram discutidos até que Lucia assumiu o posto de Ademar na marcação cerrada, porém disfarçada, junto às instituições policiais. De posse de um bloquinho e caneta levantados no ar como querendo mostrar que vai tomar nota, pergunta ao capitão se a companhia está bem equipada, se tem viaturas suficientes e se o efetivo "está ok". Depois que o capitão afirma que "está tudo ok", Lucia concorda que a 3a Cia. teria melhorado e se dirige ao delegado para saber se a delegacia estava bem aparelhada e explica a razão do questionamento - que a população precisa reivindicar, deixando implícito nessa suposta tentativa de ajudar as polícias, que as demandas serão direcionadas ao poder político, talvez pegando onda nas manifestações de junho embora não fossem "agitadores". O delegado explica a situação, reclama da escassez de escrivães, do tamanho da área pela qual eles ficam responsáveis no período noturno, que a região é o pior lugar de São Paulo para se trabalhar, que em termos de computadores e viaturas estaria satisfeito, mas que havia falta de pessoal. Lucia parece determinada na sua tarefa sutil, porém insistente de pressionar a polícia e conta que um policial, sem dizer se militar ou civil, mas se dirigindo ao capitão, teria lhe confidenciado o quanto era difícil seu cotidiano e de seus colegas sofrendo discriminação e sendo mal tratados, tanto por civis quanto pelos superiores e que este mesmo policial lhe teria pedido que levasse esse apelo ao Conseg, sem revelar sua identidade. Ademar mais uma vez intervém em defesa da polícia, desqualificando uma acusação de que policiais no Paraná teriam torturado suspeitos inocentes fazendo-os confessar crimes que não haviam cometido ${ }^{105}$. Em seguida afirmou que os policiais sofreriam discriminação, que seriam

\footnotetext{
${ }^{104}$ No fim de julho, mês da reunião em que ocorreram as falas relatadas, o governo de Fernando Haddad na prefeitura de São Paulo completava sete meses.

${ }^{105}$ Ademar estava se referindo a um caso de uma adolescente desaparecida no estado do Paraná. Quatro homens que trabalhavam em um parque de diversões foram presos e torturados para confessar o estupro e assassinato da jovem. A única coisa que os ligava ao crime era o fato de que o parque de diversões em que trabalhavam ficava no caminho que a adolescente percorria diariamente. Quando o corpo da adolescente foi
} 
julgados injustamente pois "todo mundo olha o que o policial faz, mas que quando é o criminoso, ninguém sabe, ninguém viu". Lucia retoma seu levantamento, dessa vez junto ao inspetor da Guarda Civil Metropolitana que reclama da falta de viaturas. Lucia continua, abordando por um tempo relativamente longo assuntos aparentemente sem relação: lembra que o 47으 DP havia passado por uma reforma, que os moradores queriam fazer a parte deles e defende, retomando a suposta confidência cuja fonte policial não pode revelar, que deveria haver tratamento igualitário entre oficiais e guardas. Alguns minutos depois o presidente encerra a reunião.

Analisando em perspectiva o longo relato acima, a impressão é que as falas de Ademar e Lucia foram estrategicamente orquestradas com uma técnica de avanço e recuo ou, na linguagem coloquial: morde e assopra. Cada cobrança em direção às polícias foi intercalada ou por uma defesa da própria polícia ou por uma fala agressiva, quase caricata contra a subprefeitura. Lucia e Ademar pareciam simular ingenuidade: Lucia diz que soube, através de uma suposta confidência, da difícil situação dos praças na hierarquia da polícia, situação essa que é notória entre especialistas do campo da segurança pública, mas só começou a ser discutida por um grupo maior na sociedade muito depois daquela reunião e ainda assim a discussão não se generalizou ${ }^{106}$. Com seu bloquinho explicitamente em punho, a moradora manifesta solidariedade, mas também demonstra sutilmente a disposição em não tomar pelo valor de face uma das justificativas mais comuns por parte dos policiais para a dificuldade em combater o crime: falta de efetivo, falta de equipamentos, viaturas, etc. Nesse sentido, outra justificativa recorrente por parte dos policiais é a suposta permissividade ou inadequação das leis brasileiras. Ademar começara sua abordagem à polícia trazendo para a discussão a evidência material (o jornal impresso com a notícia sobre o aumento de circulação de armas) de que mesmo as leis boas não são estão sendo colocadas em prática. Quando afirma que "o sujeito para entrar na polícia deveria ser investigado", Ademar fala, cara a cara com às autoridades, que existem policiais criminosos porque há uma falha sistêmica no processo de seleção dos membros das corporações contrariando outra justificativa dos policiais, aquela da culpa de indivíduos isolados. Já a teoria da "falta de B.O." outro arroz de festa das falas dos policiais, é confrontada por uma terceira moradora que é taxativa: não adianta fazer B.O. Mesmo Lucia, cansada de saber que o delegado vai insistir no BO, teima em relatar algumas situações em que os moradores não iriam fazer o registro.

encontrado por moradores no fundo de um poço, havia sêmen não compatível com nenhum dos suspeitos e não havia sinal de estupro. Os suspeitos denunciaram as torturas e foram incluídos em um programa de proteção a testemunhas e vários dos policiais envolvidos foram presos.

${ }^{106}$ Sobre esse assunto, consultar http://www12.senado.gov.br/noticias/materias/2013/11/13/mudancacompleta-do-sistema-policial-obtem-consenso-em-audiencia-publica-no-senado. 
Dada a situação geral observada nos outros Consegs, a postura dos três, especialmente Lucia e Ademar não é nada banal. Lucia e Ademar não são ingênuos, ao contrário, são tão argutos que não deixam de intercalar suas críticas mais implícitas ou explicitas com as defesas da polícia. Enquanto suas críticas e pontos levantados são incomuns e demonstram conhecimento adquirido fora dos Consegs, as defesas que fazem da polícia são absolutamente banais, apenas repetindo uma cantilena que cansei de ouvir nas reuniões e que sempre responsabilizam agentes externos pela performance da polícia, especialmente: os direitos humanos (evocados implicitamente no caso das denúncias de tortura no distante caso do Paraná) e o poder político (os caras que pensam que a periferia é terra de ninguém), e a negligência das vítimas (quando Ademar diz que as pessoas são displicentes em relação à ação dos criminosos). Na reunião do mês de agosto (dois meses depois) ouvi Ademar dizer em reunião que era presidente do diretório de seu partido no bairro, informação que consegui confirmar, no website de um partido em que constava seu nome e sua foto e o nome do bairro em que ele era presidente, um bairro no distrito do Capão Redondo.

Não consegui reunir elementos suficientes, ou conectá-los de forma adequada, para explicar porque essa postura de quase confronto com as autoridades policiais, única no âmbito empírico da presente pesquisa, ocorreu naquela reunião e naquele distrito. Nem mesmo a forte conexão de pelo menos um dos atores com o circuito da política partidária é capaz de explicar o resultado uma vez que essa variável não é exclusiva deste Conseg. O que é possível reter desse episódio é o caráter contido e calculado da contestação sistemática, sugerindo o receio dos atores em exercer pressão de forma explícita sobre a polícia. Em segundo lugar, embora os dados não permitam inferir que a conexão com o circuito da política formal aumenta as chances de contestação (como encontraram LAVALLE et al, 2005), é possível dizer com razoável segurança que ele não diminui essa chance.

Por fim, cabe uma ressalva. É bastante razoável supor que afinidades ou mesmo filiação partidária dos participantes tenha influência na forma como se dirigem à administração municipal ou às polícias, estas últimas na alçada do governo estadual. Todos os acompanhamentos de reunião foram realizados depois que o Partido dos Trabalhadores reconquistou a prefeitura de São Paulo com a eleição de Fernando Haddad. Desde então, cada reunião dos Consegs têm reunido membros de duas administrações públicas comandadas pelos dois mais importantes partidos brasileiros, entre os quais tem se dado as maiores disputas político-eleitorais nos últimos vinte anos. É bastante provável que esse fator tenha influência na forma como os atores se dirigem aos órgãos da administração estadual e municipal. Mas dificilmente explica sozinho a diferença, especialmente se levarmos em conta que as categorias conflito aberto e conquista da comunidade ficaram com valor zero para as instituições policiais e não é razoável supor que apenas simpatizantes do PSDB, partido que comanda o governo estadual e consequentemente as polícias, sejam ativos nos Consegs. Pelo 
contrário, o poder político não deixa de ser apontado como culpado, tal como ocorreu na fala de número 10 da reunião no Pari em 23 de maio de 2013 em que um senhor na plateia pergunta retoricamente por que o governador não estava deixando os policiais trabalharem e critica algumas medidas anunciadas na mesma semana. O próprio Ademar, membro do partido do governador, não deixou de criticar o poder político estadual "porque estamos na periferia os caras acham que é terra de ninguém".

No próximo capítulo, esses achados serão conectados a um quadro maior, levando em consideração o debate na literatura e também os achados. 


\section{AMARRANDO AS PONTAS}

\subsection{Institucionalização precária e atuação dos atores societais}

O comportamento contestatório por parte dos atores, segundo a abordagem da sociedade civil adotada por Miranda (2007), só poderia aparecer se estes estivessem em condição de autonomia, separação em relação ao Estado. Moraes (2011) já havia demonstrado que é possível haver inversão de autoridade, posturas confrontadoras por parte dos cidadãos, sem dizer nada sobre a condição de autonomia ou cooptação dos mesmos. Nesta pesquisa também foram encontrados casos que poderíamos chamar de inversão de autoridade e um conjunto de evidências de que os membros dos Consegs são capazes de exercer e exercem uma certa autonomia em relação às autoridades. Ainda assim, não são separados, mas mantêm relações de interesse recíproco com os representantes do legislativo, de modo que ficou demonstrado que essas relações não impedem uma política de confronto. Os atores estão institucionalmente embutidos e isso mantém os Consegs funcionando e impedem que sejam descontinuados, não obstante a limitação de atribuições que o governo estadual impõe sobre essas instituições.

Acontece, porém, que esses confrontos não são igualmente distribuídos entre os representantes dos diversos órgãos públicos. Há considerável diferença da relação dos moradores quando se dirigem aos representantes da subprefeitura com o dedo em riste e quando falam aos policiais, geralmente de forma mais elogiosa e conciliadora. A explicação é institucional, em um sentido mais largo: as regras importam e o regulamento dos Consegs impõe um comportamento disciplinado e hierarquicamente respeitoso na relação dos moradores com a polícia. Em outras palavras, o que impede um comportamento mais contestatório em relação às polícias não é a proximidade com atores estatais, porque essa postura se dá em relação aos membros dos órgãos não policiais. É a relação amarrada pelas regras do jogo, a relação definida por uma extensa lista de comportamentos adequados e inadequados, pautados pela lógica militar que a todo tempo parece ameaçar os atores com a não colaboração ou até mesmo a exclusão de membros em caso de quebra de hierarquia. Uma evidência adicional a favor da relevância do regulamento como fator explicativo do comportamento dos atores é o fato de que aquilo que Teresa Caldeira chamou de "a fala do crime" não se propagar nas reuniões dos Consegs, conforme foi apontado no capítulo 4, item 4.2. 0 regulamento previne todas as modalidades de participantes contra a prescrição de violação de direitos fundamentais como solução para segurança pública, alerta que parece surtir efeito. 
Além disso, os Consegs não conseguiram formalizar sua existência de forma segura e estável, pois toda a normatização que instituiu e organiza os Consegs no nível estadual são decretos e portarias, com exceção da criação das coordenadorias o que, conforme narrado no capítulo 2, por si só demonstra a dificuldade em institucionalizar esse espaço participativo. Os Consegs precisam da homologação da coordenadoria e dos membros natos para aprovar participantes e homologar eleições. Além disso, vários cargos na coordenadoria estadual são ocupados por policiais civis e militares. Em resumo, no Conseg os atores permanecem em um estado de dependência em relação aos órgãos policiais e talvez por isso as interações com a polícia seja tão pacifica. Em contraste, a relação com a esfera municipal é muito diferente: em primeiro lugar porque o Conseg não está submetido a esta esfera de governo e em segundo porque a participação dos representantes da subprefeitura, da Guarda Civil Metropolitana e da CET estão estabelecidas na lei, garantindo que esses atores estarão presentes e tornem mais atrativas as reuniões - e é com os representantes da administração municipal que falam com o dedo em riste.

\subsection{Arquitetando a participação nos momentos de grande inovação institucional}

Para lidar com a situação descrita acima, há uma vertente do neo-institucionalismo que nos sugere visitar o momento de criação dos Consegs. Comparando a participação cidade do México e São Paulo, Gurza Lavalle (2011b) defende que historicamente em SP, teria havido uma ativação societal contra a ditadura que foi se focando em reformas institucionais que prolongaram $o$ protagonismo dos novos atores da sociedade civil, consolidando sua presença em domínios de agência específicos - áreas de políticas públicas ao longo do tempo. Em comparação, na cidade do México os atores não tiveram sucesso em manter a mobilização e influenciar as respectivas agendas da política ao longo do tempo.

No momento de criação dos Consegs, aqueles atores da academia e ativistas dos direitos humanos que foram colocados por Franco Montoro para elaborar essa instituição - que inicialmente se chamavam "Conselhos Comunitários de Segurança e Defesa do Homem" - foram posteriormente afastados. As reformas pretendidas por Montoro sofreram fortes revezes pela reação de grupos das corporações policiais e de certos atores políticos. As possibilidades da reforma eram ainda mais escassas por causa da situação no plano político nacional: quando Montoro assumiu o governo estadual, o Brasil ainda era governado pelo general Figueiredo. A crise da segurança pública afastou os elementos reformadores e deu os Consegs um perfil diferente daquele inicialmente pretendido. Posteriormente houve alguma mudança incremental com o novo regulamente de 1999, mas não foi suficiente para mudar o perfil dos Consegs e a extensa lista de deveres e disciplinas que deve ser 
seguida pelos membros. Essa rigidez da regulação do executivo estadual sobre os Consegs também fica evidente nas sucessivas tentativas de aumentar as atribuições dessas instituições por meio de leis de iniciativas de vários deputados de diversas legendas e que sucessivamente foram bloqueadas

\subsection{A questão dos direitos civis de um lado e direitos sociais e políticos de outro}

Inserindo os resultados da pesquisa na discussão sobre os problemas postos na questão dos direitos insuficientes, tanto na literatura sobre os Consegs quanto na literatura mais geral sobre crime, medo e violência, a pesquisa trouxe evidências no sentido de nuançar hipóteses anteriores e reforçar as hipóteses a seguir.

Os Consegs não pioram o quadro da rejeição aos direitos civis em relação aquilo que normalmente está presente na sociedade, um resultado no sentido oposto daquele encontrado por Galdeano (2009). Já no que tange a um ambiente de "cultura do controle" encontrado por Moraes (2011) e também prejudicial às garantias fundamentais dos indivíduos, esse diagnóstico foi nuançado pelos indícios encontrados de problemas específicos de segurança movem os cidadãos aos Consegs. Não é só a desordem percebida no espaço público que os faz participar, mas problemas tangíveis de criminalidade.

Em termos de direitos sociais, os Consegs são capazes de diminuir disparidades no acesso a bens públicos em benefício das faixas de renda mais baixas, porém, são insuficientes para superar desafios relacionados à baixa escolaridade na participação e, possivelmente, essa baixa participação tem consequência para a menor taxa de satisfação entre os Consegs dos distritos com maiores porcentagens de analfabetos.

Nesse sentido, ainda que a análise pretenda-se multidimensional para explicar um objeto, alguma extrapolação teórica é possível, mesmo em fase de esboço. Para Zaluar, uma certa parte do campo sobre crime, medo e violência adotou “...uma crítica cultural, denunciando a natureza violenta da sociedade brasileira e a sua falta de concepção de cidadania" (1999, p. 26). A crítica cultural descrita por Zaluar continua sendo o ponto de apoio ao qual os trabalhos sobre crime, medo e violência tendem a voltar.

Definições implicam na especificidade de um determinado objeto, nesse caso, da cultura brasileira que seria especificamente hierárquica e desigual (ausência de concepção de cidadania, de igualdade de todos perante a lei) em comparação com o geral, algo como a média das demais culturas do mundo. Se Kant de Lima (1997, 2004) e Roberto DaMatta (1997 [1979]) assumem suas percepções do mundo anglo-saxão como parâmetros de comparação sem 
maiores problemas, José Murilo de Carvalho e Teresa Caldeira (2000) não deixam de mencionar que podem haver implicações em comparar o caso Brasil com modelos que são, ao fim e ao cabo, tipos ideais, versões estilizadas do que seria o desenvolvimento da cidadania em certos países ocidentais industrializados. Na prática, isso não os impede de corroborar interpretações de cidadania invertida. Além do problema do objeto ao qual se compara, há o problema de se assumir uma unidade cultural para o país, algo improvável. Esses traços fundamentais da cultura brasileira são mobilizados para se explicarem mutuamente em um argumento às vezes circular.

Quando essas matrizes orientam os estudos sobre os Consegs, evidências de que a afirmação dos diferentes direitos civis, sociais e políticos não se dão em blocos (not all good/bad things go together), são atribuídas à diferença entre a esfera do discurso e a esfera da prática. A doutrina da interdependência entre os direitos emanada da Conferência de Direitos Humanos de Viena de $1993^{107}$ - destinada a ser um instrumento político na defesa dos direitos humanos - só veio dar mais força a essa paradigma epistemológico que ainda é dominante nesses estudos.

Além disso, o domínio dessa matriz teórica deixa pouco espaço para compreensões alternativas, para entendimentos microssociológicos dos fenômenos. Explicações institucionalistas dos tipos propostos neste trabalho dão conta de uma porção pequena da compreensão dos fenômenos estudados, limitação que não acomete a matriz da interdependência dos direitos, o que talvez explique a preferência dominante por essa opção nos estudos sobre crime, medo e violência.

Estudando os Consegs, pretendi, sobretudo, lançar luz sobre esse objeto especificamente. Com sorte, novos olhares sobre os objetos relacionados aos temas do crime, medo e violência poderão se beneficiar de explicações alternativas e o debate pode ser assim enriquecido a partir de uma maior pluralidade de pontos de vistas.

\footnotetext{
107 “5. All human rights are universal, indivisible and interdependent and interrelated [...] 8. Democracy, development and respect for human rights and fundamental freedoms are interdependent and mutually reinforcing." Declaração e programa de ação adotado pela Conferência Mundial de Direitos Humanos de Viena, em junho de 1993.
} 


\section{REFERÊNCIA BIBLIOGRÁFICA}

ADORNO, Sérgio. Monopólio estatal da violência na sociedade brasileira contemporânea. In: MICELI Sergio, (Org). 0 que ler na ciência social brasileira. São Paulo: ANPOCS: Editora Sumaré/CAPES, 2002.

ADORNO, Sérgio. A gestão urbana do medo e da insegurança: Violência, Crime e Justiça Penal na Sociedade Brasileira Contemporânea. 282 f. Tese (Livre-docência em sociologia) - Faculdade de Filosofia, Letras e Ciências Humanas. Universidade de São Paulo, São Paulo. 1996.

AVRITZER, L. (Org.) A participação em São Paulo. 1. ed. São Paulo: Editora Unesp, 2004. v. 1. 470p.

BAUMAN, Zygmunt. Lei global, ordens locais. In: Globalização: as consequências humanas. Rio de Janeiro: Jorge Zahar, 1999, p.111-136.

CALDEIRA, Teresa Pires do Rio. Cidade de muros: crime, segregação e cidadania em São Paulo. São Paulo: Editora 34 / Edusp, 2000.

CÂMARA DOS DEPUTADOS. Perfis Parlamentares. 54. Brasília, 2009. Biblioteca Digital da Câmara dos Deputados. Centro de Documentação e Informação.

CAMPOS, Marcelo Silveira. Escolha racional e criminalidade: uma avaliação crítica do modelo. Revista da Seção Judiciária do Rio de Janeiro, n 22, p. 93-110, 2008.

CARDIA, Nancy. Exposição à violência: seus efeitos sobre valores e crenças em relação a violência, polícia e direitos humanos. Lusotopie, 299-328, 2003.

CARDIA, Nancy; ADORNO, Sérgio; POLETO, Frederico. Homicídio e violação de direitos humanos em São Paulo. Estudos Avançados, São Paulo, v. 17, n. 47, Abril de 2003.

CARNEIRO, Leandro Piquet. Democratic consolidation and civil rights: Brazil in comparative perspective. In (Ed.): KINZO, Maria D’Alva; DUNKERLEY, James. Brazil since 1985: Politics, Economy and Society. London: Institute of Latin American Studies / University of London, 2003.

CARVALHO, José Murilo. Cidadania no Brasil: o longo caminho. Rio de Janeiro: Civilização Brasileira, 2010.

COELHO, Edmundo Campos. A criminalização da marginalidade e a marginalização da criminalidade. Revista de Administração Pública, Rio de Janeiro, 12(2)139-161, abr./jun. 1978.

COELHO, Edmundo Campos. Sobre sociólogos, pobreza e crime. Dados: Revista de Ciências Sociais: Rio de Janeiro, v. 23, n. 3, 377-383, 1980.

COELHO, Sandro Anselmo. O Partido Democrata Cristão: teores programáticos da terceira via brasileira (1945-1964). Rev. Bras. Hist. [online]. 2003, vol.23, n.46 [cited 2012-05-13], pp. 201-228 . Available from: $\quad$ http://www.scielo.br/scielo.php?script=sci_arttext\&pid=S010201882003000200009\&Ing=en\&nrm=iso>. ISSN 1806-9347. http://dx.doi.org/10.1590/S0102$\underline{01882003000200009}$

COLLIER, R., COLLIER, D. Shaping the Political Arena: Critical Junctures, the Labor Movement, and Regime Dynamics in Latin America. Princeton: Princeton University Press, 1991. 
DAGNINO, E. (Org.) Sociedade Civil e Espaços Públicos no Brasil. São Paulo: Paz e Terra, 2002.

DAMATTA, Roberto. Carnavais, malandros e heróis: para uma sociologia do dilema brasileiro. Rio de Janeiro: Rocco, 1997.

EVANS, Peter. Embeded autonomy: States and industrial transformation. Princeton: Princeton University Press, 1995.

FELTRAN, Gabriel de Santis. Fronteiras de tensão: política e violência nas periferias de São Paulo. São Paulo: Unesp/CEM, 2011.

GALDEANO, Ana Paula. Para Falar em Nome da Segurança: o que pensam, querem e fazem os representantes dos Conselhos Comunitários de Segurança. 2009. 304 f. Tese (Doutorado em Ciências Sociais) - Instituto de Filosofia e Ciências Humanas, Universidade Estadual de Campinas, Campinas, 2009.

GARLAND, David. Punishment and Modern Society: a study in social theory. Chicago: Oxford University, 1993.

GARLAND, David. La cultura del control: crimen y orden social el la sociedad contemporánea. Barcelona: Gedisa Editorial, 2005.

GURZA LAVALLE, Adrian (Org.). Após a participação. Lua Nova. No 84. São Paulo: CEDEC, 2011a.

GURZA LAVALLE, Adrian. La construcción política de las sociedades civiles. In: (Org.). El horizonte de la política - Brasil y la agenda contemporánea de investigación en el debate internacional. México: CIESAS, 2011b, p. 207-268.

GURZA LAVAlLE, Adrian; ACHARYA, Arnab; HOUTZAGER, PETER P. Beyond Comparative Anecdotalism: Lessons on Civil Society and Participation from São Paulo, Brazil. World Development Vol. 33, No. 6, pp. 951-964, 2005.

HOUTZAGER, P. Introduction: From Polycentrism to the Polity. In HOUTZAGER, P., MOORE, M. (Eds). Changing Paths: International Development and the New Politics of Inclusion. Ann Arbor: Michigan University Press, 2003.

JESUS, Maria Gorete Marques; OI, Amanda Hildebrand; ROCHA, Thiago Thadeu e LAGATTA, Pedro. Prisão Provisória e Lei de Drogas: Um estudo sobre os flagrantes de tráfico de drogas na cidade de São Paulo. São Paulo: Núcleo de Estudos da Violência, Open Society Foundation, 2011. Relatório de Pesquisa do Núcleo de Estudos da Violência.

KANT DE LIMA, Roberto. Polícia e exclusão na cultura judiciária. Tempo Social: Revista de sociologia da USP: São Paulo, 9(1); 169-183, maio de 1997.

KANT DE LIMA, Roberto. Direitos civis e Direitos Humanos: uma tradição judiciária pré-republicana? São Paulo em Perspectiva. São Paulo, v. 18, n. 1, Mar. 2004.

MESQUITA NETO, Paulo. Ensaios sobre segurança cidadã. São Paulo: Quartier Latin/FAPESP, 2011.

MINGARDI, Guaracy. Tiras, gansos e trutas: cotidiano e reforma da polícia civil. São Paulo: Scritta Editorial, 1992.

MIRANDA, Ana Paula Mendes. A busca por direitos: possibilidades e limites da participação social na democratização do Estado. In: Caruso, Haydée; Muniz, Jacqueline; Blanco, Antonio Carlos Carballo 
(Org.). Polícia, Estado e Sociedade: práticas e saberes latino-americanos. Rio de Janeiro: Publit, 2007, v., p. 417-443.

MONTORO, André Franco. Da democracia que temos para a democracia que queremos. São Paulo: Editora Paz e Terra, 1974.

MONTORO, André Franco. Alternativa comunitária: um caminho para o Brasil. Rio de Janeiro: Nova Fronteira, 1982.

MORAES, Luciane Patrício Braga. Falar, ouvir e escutar: Etnografia dos processos de produção de discursos e de circulação da palavra nos rituais de participação dos conselhos comunitários de segurança. 2011. 311 f. Tese (Doutorado em Antropologia) - Universidade Federal Fluminense, Niterói, 2011.

PERALVA, Angelina. Violência e democracia: o paradoxo brasileiro. São Paulo: Paz e Terra, 2000.

PIRES, Roberto Rocha C. (Org.). Efetividade das Instituições Participativas no Brasil: Estratégias de Avaliação - volume 7. Brasília: IPEA, 2011. (Série Diálogos para o Desenvolvimento).

PIERSON, Paul. Positive Feedback and Path Dependence. In Politics in Time. Princeton: Princeton University Press, 2004.

PINHEIRO, Paulo Sérgio. Transição política e não-estado de direito na República. In PINHEIRO, Paulo Sérgio; SACHS, Ignacy; WILHEIM, Jorge. Brasil, um século de transformações. São Paulo: Companhia das Letras, 2001.

SALLA, Fernando; GAUTO, Maitê e ALVAREZ, Marcos César. A contribuição de David Garland a sociologia da punição. Tempo Social, revista de sociologia da USP, v. 18, n. 1. Junho 2006.

SANTOS, Wanderley Guilherme dos. Cidadania e Justiça: A política social na ordem brasileira. 3.a ed. Rio de Janeiro: Campus, 1994.

SKOCPOL, Theda. Protecting Soldiers and Mothers: The political origins of Social policy in the United States. Cambridge: Harvard University Press, 1992.

SOARES, Luiz Eduardo; CARNEIRO, Leandro Piquet. Os quatro nomes da violência: um estudo sobre éticas populares e cultura política. In: (Org) SOARES, Luiz Eduardo. Violência e política no Rio de Janeiro. Rio de Janeiro: ISER/Relume Dumará, 1996.

SOARES, Luiz Eduardo; SENTO SÉ, João Trajano; RODRIGUES, João Augusto de Souza; CARNEIRO, Leandro Piquet. Criminalidade urbana e violência: o Rio de Janeiro no contexto internacional. In: (Org) SOARES, Luiz Eduardo. Violência e política no Rio de Janeiro. Rio de Janeiro: ISER/Relume Dumará, 1996.

SSP-SP - Secretaria de Segurança Pública do Estado de São Paulo. Coletânea Consegs: legislação, normas e modelos. São Paulo, 2011.

http://www.conseg.sp.gov.br/DownloadDetalhe.aspx?id grupo=4. Download em Novembro de 2013.

WACQUANT, Loïc. O lugar da prisão na nova administração da pobreza. Novos Estudos, 80, março, pp.09-19. 2008.

WIEVIORKA, Michel. O novo paradigma da violência. Tempo Social, São Paulo, vol.9, n.1, p.5-41. 1997. 
ZALUAR, Alba. Condomínio do Diabo. Rio de Janeiro: Revan: Ed. UFRJ, 1994.

ZALUAR, Alba. A Máquina e a Revolta: Organizações populares e o significado da pobreza. Rio de Janeiro: Editora Brasiliense, 2000 (primeira edição 1985).

ZALUAR, Alba. Um debate disperso: violência e crime no Brasil da redemocratização. São Paulo em Perspectiva. São Paulo, v. 13, n. 3, Set. 1999. 
APÊNDICE A - LISTA FINAL DAS ATAS DA AMOSTRAGEM

\begin{tabular}{|c|c|c|c|c|c|}
\hline Conseg & Data & Estrato & Conseg & Data & Estrato \\
\hline Artur Alvim & Sep-11 & 1 & A. E Carvalho & Feb-10 & 2 \\
\hline Cj Jose bonifacio & May-12 & 1 & Bom Retiro & Mar-12 & 2 \\
\hline grajau & Jul-10 & 1 & Campo Limpo & Oct-11 & 2 \\
\hline grajau & Aug-10 & 1 & Freguesia do Ó & Feb-11 & 2 \\
\hline grajau & Oct-10 & 1 & Freguesia do Ó & May-11 & 2 \\
\hline grajau & Mar-11 & 1 & Freguesia do Ó & Sep-11 & 2 \\
\hline Itaim Paulista & May-11 & 1 & Jaçana & Oct-11 & 2 \\
\hline Jardim Angela & Mar-10 & 1 & Jardim São Luiz & Aug-10 & 2 \\
\hline Jardim Angela & Jul-10 & 1 & Parque Bristol & Feb-10 & 2 \\
\hline Jardim Bonifácio & Nov-10 & 1 & Parque Bristol & May-10 & 2 \\
\hline Lageado & Aug-11 & 1 & Parque Bristol & Oct-12 & 2 \\
\hline Parelheiros & Mar-10 & 1 & Parque Novo Mundo & Aug-10 & 2 \\
\hline Parque São Rafael & May-11 & 1 & Penha & Jun-11 & 2 \\
\hline Perus & Feb-12 & 1 & Penha & Oct-11 & 2 \\
\hline São Mateus & May-10 & 1 & Raposo Tavares & Jun-10 & 2 \\
\hline São Mateus & Jun-10 & 1 & Raposo Tavares & Jul-11 & 2 \\
\hline São Miguel Paulista & Nov-11 & 1 & Vila Joaniza & Sep-10 & 2 \\
\hline Teotonio Vilela & Jan-10 & 1 & Vila Joaniza & Sep-11 & 2 \\
\hline Teotonio Vilela & Apr-12 & 1 & Vila Joaniza & Oct-12 & 2 \\
\hline Teotonio Vilela & Jun-12 & 1 & Vila Joaniza & Nov-12 & 2 \\
\hline Vila Brasilândia & Sep-10 & 1 & Vila Matilde & Apr-10 & 2 \\
\hline Vila Penteado & Jul-12 & 1 & Vila Matilde & Jun-10 & 2 \\
\hline Capao Redondo & Sep-12 & 1 & Vila Sta Maria & Sep-10 & 2 \\
\hline Itaquera & May-11 & 1 & São Lucas & Nov-10 & 2 \\
\hline Jardim Mirna & Apr-10 & 1 & Vila Jacui & Jul-11 & 2 \\
\hline Jardim Miriam & Feb-12 & 1 & Guaianazes & Oct-10 & 2 \\
\hline Jardim Robru & Jun-11 & 1 & Aricanduva & Jul-11 & 2 \\
\hline
\end{tabular}

(Continua) 


\begin{tabular}{|c|c|c|c|c|c|}
\hline Conseg & Data & Estrato & Conseg & Data & Estrato \\
\hline Belem & Mar-12 & 3 & Brooklin & Mar-10 & 4 \\
\hline Bras/Mooca & Nov-11 & 3 & Cambuci & Jun-10 & 4 \\
\hline Centro & Jun-12 & 3 & Campo Grande & Sep-12 & 4 \\
\hline Centro & Aug-12 & 3 & Consolacao & Feb-10 & 4 \\
\hline Cidade Ademar & Jun-10 & 3 & Consolacao & Nov-10 & 4 \\
\hline Cidade Ademar & May-12 & 3 & Itaim Bibi & Feb-10 & 4 \\
\hline Cidade Ademar & Nov-12 & 3 & Itaim Bibi & Jun-10 & 4 \\
\hline Interlagos & Sep-10 & 3 & Jardins/Paulista & Aug-10 & 4 \\
\hline Ipiranga & Apr-10 & 3 & Lapa & Sep-11 & 4 \\
\hline Jaguaré & Feb-10 & 3 & Mooca & Oct-12 & 4 \\
\hline Jaguaré & Aug-12 & 3 & Morumbi & Feb-10 & 4 \\
\hline Jaguaré & Oct-12 & 3 & Morumbi & Mar-11 & 4 \\
\hline Pari & Feb-10 & 3 & Morumbi & Oct-11 & 4 \\
\hline Pari & Jun-11 & 3 & Parque são jorge & Feb-11 & 4 \\
\hline Pari & Oct-12 & 3 & Perdizes & Aug-10 & 4 \\
\hline Pirituba & Jan-11 & 3 & Portal morumbi & Feb-11 & 4 \\
\hline Sacoma & Feb-10 & 3 & Santa Cecilia & Sep-11 & 4 \\
\hline Vila Formosa & May-10 & 3 & Santa Cecilia & Oct-12 & 4 \\
\hline Vila Formosa & Jun-11 & 3 & Santo Amaro & Sep-12 & 4 \\
\hline Vila Gustavo & Jun-12 & 3 & Santo Amaro & Nov-12 & 4 \\
\hline Vila Gustavo & Nov-12 & 3 & tatuape & Feb-12 & 4 \\
\hline Vila Maria & Apr-11 & 3 & tatuape & Aug-12 & 4 \\
\hline Vila Prudente & May-11 & 3 & Vila Clementino & Aug-11 & 4 \\
\hline Vila Amalia & Feb-10 & 3 & Vila Leopoldina & Jun-11 & 4 \\
\hline Vila Pereira Barreto & Aug-11 & 3 & Agua Fria Mandaqui & Feb-12 & 4 \\
\hline Vila Diva & Oct-11 & 3 & Pinheiros & Oct-12 & 4 \\
\hline Casa Verde/Santana & Mar-12 & 3 & Campo Belo & Apr-12 & 4 \\
\hline
\end{tabular}




\section{APÊNDICE B - TABELAS COMPARATIVAS DOS MODELOS ANÁLISES DE REGRESSÃO}

B. 1 - Tabela comparativa modelos de regressão logística para a variável dependente "Satisfação". Até o modelo 05 , o número de observações é menor porque nem todas as atas da amostragem traziam a informação do número de participantes na reunião. Depois que a variável taxa de participação é retirada do modelo, o número de observações aumenta. 0 modelo 08 é aquele com melhor adequação e foi utilizado na análise.

\begin{tabular}{|c|c|c|c|c|c|c|c|c|}
\hline & $\begin{array}{l}\text { Modelo } \\
01\end{array}$ & $\begin{array}{l}\text { Modelo } \\
02\end{array}$ & $\begin{array}{l}\text { Modelo } \\
03\end{array}$ & $\begin{array}{l}\text { Modelo } \\
04\end{array}$ & $\begin{array}{l}\text { Modelo } \\
05\end{array}$ & $\begin{array}{l}\text { Modelo } \\
06\end{array}$ & $\begin{array}{l}\text { Modelo } \\
07\end{array}$ & $\begin{array}{l}\text { Modelo } \\
08\end{array}$ \\
\hline$\%$ pobres & $1.176 \mathrm{~m}$ & $1.174 \mathrm{~m}$ & $1.159 * *$ & $1.169 * *$ & $1.179 * *$ & $1.162 * *$ & $1.152 * *$ & $1.160 * *$ \\
\hline$\%$ ricos & $1.020 \mathrm{~m}$ & $1.020 \mathrm{~mm}$ & - & - & - & - & - & - \\
\hline$\%$ analfabetos & $\begin{array}{l}.311 \\
(p=0.065)\end{array}$ & $.319 *$ & $.333 * *$ & $.309 * *$ & $.352 * *$ & $.464 *$ & $.513^{*}$ & $.487 *$ \\
\hline Taxa de roubos & $\begin{array}{l}1.000 \\
(p=0.057)\end{array}$ & $\begin{array}{l}1.000 \\
(p=0.056)\end{array}$ & $\begin{array}{l}1.000 \\
(p=0.057)\end{array}$ & $\begin{array}{l}1.000 \\
(p=0.056)\end{array}$ & $\begin{array}{l}1.000 \\
(p=0.081)\end{array}$ & $\begin{array}{l}1.000 \\
(p=0.083)\end{array}$ & $1.000 \mathrm{~m}$ & - \\
\hline Taxa de furtos & $.999 \mathrm{~m}$ & $.999 \mathrm{~m}$ & $.999 \mathrm{~m}$ & $.999 \mathrm{~m}$ & $.999 \mathrm{~m}$ & $.999 \mathrm{~m}$ & - & - \\
\hline $\begin{array}{l}\text { Taxa de homicídios } \\
\text { atual }\end{array}$ & $1.023 \mathrm{~m}$ & $1.024 \mathrm{~m}$ & $1.023 \mathrm{~m}$ & $1.021 \mathrm{~m}$ & - & - & - & - \\
\hline $\begin{array}{l}\text { Taxa histórica de } \\
\text { homicídios }\end{array}$ & $1.000 \mathrm{~m}$ & - & - & - & - & - & - & - \\
\hline $\begin{array}{l}\text { Presença de repre- } \\
\text { sentante }\end{array}$ & $1.150 \mathrm{~mm}$ & $1.150 \mathrm{~mm}$ & $1.145 \mathrm{~m}$ & - & - & - & - & - \\
\hline Taxa de participação & $.994 \mathrm{~m}$ & $.994 \mathrm{~m}$ & $.994 \mathrm{~m}$ & $.995 \mathrm{~m}$ & $.995 \mathrm{~m}$ & - & - & - \\
\hline Constante & $.054 * *$ & $.054 * *$ & $.063 * * *$ & $.066^{* * *}$ & $.061 * * *$ & $.048 * * *$ & $.054 * * *$ & $.055 * * *$ \\
\hline LR chi2 & 15.87 & 15.87 & 15.84 & 15.45 & 14.87 & 13.80 & 10.91 & 10.49 \\
\hline Prob $>$ chi 2 & 0.069 & 0.044 & 0.026 & 0.017 & 0.010 & 0.008 & 0.012 & 0.005 \\
\hline № observações & 988 & 988 & 988 & 988 & 988 & $1135)$ & 1135 & 1135 \\
\hline
\end{tabular}

$* * * p<.001 \quad * * p<.01 \quad * p<.05 \quad$ mp $>.1$


B. 2 - Tabela comparativa modelos de regressão logística para a variável dependente "taxa de participação". O modelo 06 é aquele com melhor poder explicativo (maior valor de R ajustado) e foi utilizado na análise.

\begin{tabular}{|c|c|c|c|c|c|c|}
\hline & Modelo 01 & Modelo 02 & Modelo 03 & Modelo 04 & Modelo 05 & Modelo 06 \\
\hline$\%$ log pobres & $1.051^{*}$ & $1.049 *$ & $1.034 *$ & $1.046 *$ & $.993^{*}$ & $.757^{*}$ \\
\hline$\%$ log ricos & $.067 \mathrm{~m}$ & $.067 \mathrm{~m}$ & $.067 \mathrm{~m}$ & $.069 \approx$ & $.070 \mathrm{~m}$ & - \\
\hline$\% \log$ analfabetos & $\begin{array}{l}-.628 \\
(p=0.069)\end{array}$ & $-.627 *$ & $-.619 *$ & $-.641 * *$ & $-.591^{* *}$ & $-.578^{* *}$ \\
\hline Log taxa de roubos & $.150 \mathrm{~m}$ & $.151 \mathrm{~mm}$ & $.146 \mathrm{~m}$ & $.144 \mathrm{~m}$ & - & - \\
\hline Log taxa de furtos & $.312 \mathrm{~m}$ & $.312 \mathrm{~m}$ & $.313 \mathrm{~m}$ & $.302 *$ & $.395^{* * *}$ & $.445 * * *$ \\
\hline $\begin{array}{l}\text { Log taxa de homicídios } \\
\text { atual }\end{array}$ & $-.023 \mathrm{~m}$ & $-.022 \mathrm{~m}$ & $-.021 \mathrm{~m}$ & - & - & - \\
\hline $\begin{array}{l}\text { Log taxa histórica de } \\
\text { homicídios }\end{array}$ & $.001 \mathrm{~m}$ & - & - & - & - & - \\
\hline $\begin{array}{l}\text { Presença de represen- } \\
\text { tante }\end{array}$ & $-.017 \mathrm{~m}$ & -.017 씄 & - & - & - & - \\
\hline Constante & -2.199 м & -2.192 m & $-2.14 m$ & $-2.12 m$ & $-1.667 \mathrm{~m}$ & $-1.56 m$ \\
\hline Prob $>F$ & 0.000 & 0.000 & 0.000 & 0.000 & 0.000 & 0.000 \\
\hline Adj R-squared & 0.413 & 0.420 & 0.426 & 0.461 & 0.436 & 0.453 \\
\hline № observações & 99 & 99 & 99 & 99 & 99 & 99 \\
\hline
\end{tabular}

$* * * p<.001 \quad * * p<.01 \quad * p<.05 \quad$ mp $>.1$ 